Review

\title{
Mechanisms With Rigid Memory
}

\author{
Relly Victoria Virgil Petrescu \\ ARoTMM-IFToMM, Bucharest Polytechnic University, Bucharest, (CE), Romania
}

\section{Article history}

Received: 24-05-2019

Revised: 28-05-2019

Accepted: 17-07-2019

E-mail: rvvpetrescu@gmail.com

\begin{abstract}
Along with gears, distribution mechanisms are the most widely used mechanical transmissions used over the past 300 years and will continue to be the most widespread in all industrial fields but also in other technical areas. For this reason, it was considered necessary this work, which tries to add a brick to the permanent construction of rigid memory mechanisms used especially as distribution mechanisms for motor vehicles. The paper presents some essential aspects of the synthesis of the distribution mechanisms.
\end{abstract}

Keywords: Robots, Mechatronic Systems, Structure, Machines, Kinematics, Dynamics, Synthesis, Distribution Mechanisms, Automation

\section{Introduction}

An engine mechanism is a mechanism of a force machine which, in the case of an engine machine, transmits and eventually transforms the movement caused by the internal energy transformation of the working agent (combustion gases, steam, compressed air) into the motor shaft, or in the case of generating machines (e.g., piston compressors), vice versa, from the shaft to the working agent.

In motor machines, the mechanical work is initially obtained in the form of reciprocal movement of the piston in the cylinder. The motor mechanism turns this movement into a continuous rotary motion of the shaft.

For standard internal combustion engines, the engine is based on a crank-shaft mechanism. By extension of language, the motor mechanism means not only moving parts but also fixed ones to the frame (chassis, etc.), even if they move with the vehicle it propels (motor vehicle, locomotive, airplane, boat, etc.).

Components considered to be fixed are:

The engine block

Cylinder

Engine cylinder

Intake manifold

Exhaust manifold

Bearing cams, along with the Cartridge of the bearings

Mobile components are:

piston

segments

pin

White, along with the cufflinks

Crankshaft

The flywheel, along with the torsion oscillator.
The distribution mechanism is an auxiliary system of the internal combustion engine, the steam engine having the function of correlating the filling of the engine cylinders with fuel, steam, air and flue gas or air.

The distribution mechanism is used in almost all four-stroke internal combustion engines, except for the Wankel engine and two-stroke engines.

Depending on the type of engine to which it is applied, the distribution may be for four-stroke or twostroke engines.

The distribution to two-stroke engines, in general, is without valves and has window-in-cylinder cylinders that are closed or open by moving the piston, which is also called light distribution. Two-stroke engines, especially those with compression ignition, have only intake or exhaust valves.

The four-stroke engine distribution uses a valve mechanism that can be operated mechanically, pneumatically, magnetically or hydraulically. In most cases (mechanical, hydraulic), the valves are driven by spikes or directly by the camshaft.

Following the position of the valves, the distribution mechanism may be with side valves, with valves in the head, or with a mixed distribution mechanism.

Side valve distributor mechanism (SV; eng., Side Valves) for example small engines with a narrower (low) cylinder head. In this case, the valves are in the engine block or the cylinder.

Distributor mechanism with valves in the head, with this mechanism the valves, are mounted in the cylinder above the piston.

Mixed distribution mechanism when the valves are also mounted in the engine block and cylinder head.

After camshaft mounting, there is a camshaft mounted camshaft mechanism and camshaft mounted on the cylinder head. 
On the crankshaft mounted camshaft, the valves are hinged by hinges, their rods and tilts (OHV, eng., Over Head Valves).

On camshaft mounted Overhead Camshaft (OHC), the valves are driven by swinging or direct valve engagement.

After engaging the camshaft:

Belt

Chain

Gear

The distribution system of an internal combustion engine for automobiles is the set of all parts that allow for the regular change of gas from the cylinders. To function, an internal combustion engine needs fresh air or an air-fuel mixture to be introduced into the cylinders instead of residual flue gases to be discharged. Briefly, the distribution system provides fresh air/mixture into the cylinders and flue gas outlet.

\section{Components of the Distribution System (Fig. 1)}

Four-stroke engines have valve distribution systems. There are also distribution systems with lights/slides (two-stroke engines) or drawers (racing cars) or combined, lights and valves (two-stroke engines):

- Camshaft drive gear (belt drive)

- Cylinder

- Drain connection channels

- Exhaust valve

- Exhaust valve hatch

- $\quad$ Spindle shaft (evacuation)

- Clavicle shaft (intake)

- Inlet valve

- Admire valve hatcher

The toothed drive wheel (1) is connected via a crankshaft timing belt. The crankshaft position must be synchronized with the camshaft position because opening and closing of the valves ( 4 and 8 ) are made according to the position of the pistons in the cylinder. For the system shown, the valves are actuated via the guides (5 and 9), (Rulkov et al., 2016; Agarwala, 2016; Babayemi, 2016; Gusti and Semin, 2016; Mohamed et al., 2016; Wessels and Raad, 2016; Maraveas et al., 2015; Khalil, 2015; RhodeBarbarigos et al., 2015; Takeuchi et al., 2015; Li et al., 2015; Vernardos and Gantes, 2015; Bourahla and Blakeborough, 2015; Stavridou et al., 2015; Ong et al., 2015; Dixit and Pal, 2015; Rajput et al., 2016; Rea and Ottaviano, 2016; Zurfi and Zhang, $2016 \mathrm{a}-\mathrm{b}$; Zheng and Li, 2016; Buonomano et al., 2016 a-b; Faizal et al., 2016; Cataldo, 2006; Ascione et al., 2016; Elmeddahi et al., 2016; Calise et al., 2016; Morse et al., 2016; Abouobaida, 2016; Rohit and Dixit, 2016; Kazakov et al., 2016; Alwetaishi, 2016; Riccio et al., 2016 a-b; Iqbal, 2016;
Hasan and El-Naas, 2016; Al-Hasan and Al-Ghamdi, 2016; Jiang et al., 2016; Sepúlveda, 2016; Martins et al., 2016; Pisello et al., 2016; Jarahi, 2016; Mondal et al., 2016; Mansour, 2016; Al Qadi et al., 2016b; Campo et al., 2016; Samantaray et al., 2016; Malomar et al., 2016; Rich and Badar, 2016; Hirun, 2016; Bucinell, 2016; Nabilou, 2016b; Barone et al., 2016; Chisari and Bedon, 2016; Bedon and Louter, 2016; Santos and Bedon, 2016; Minghini et al., 2016; Bedon, 2016; Jafari et al., 2016; Chiozzi et al., 2016; Orlando and Benvenuti, 2016; Wang and Yagi, 2016; Obaiys et al., 2016; Ahmed et al., 2016; Jauhari et al., 2016; Syahrullah and Sinaga, 2016; Shanmugam, 2016; Jaber and Bicker, 2016; Wang et al., 2016; Moubarek and Gharsallah, 2016; Amani, 2016; Shruti, 2016; Pérez-de León et al., 2016; Mohseni and Tsavdaridis, 2016; Abu-Lebdeh et al., 2016; Serebrennikov et al., 2016; Budak et al., 2016; Augustine et al., 2016; Jarahi and Seifilaleh, 2016; Nabilou, 2016a; You et al., 2016; AL Qadi et al., 2016a; Rama et al., 2016; Sallami et al., 2016; Huang et al., 2016; Ali et al., 2016; Kamble and Kumar, 2016; Saikia and Karak, 2016; Zeferino et al., 2016; Pravettoni et al., 2016; Bedon and Amadio, 2016; Chen and $\mathrm{Xu}, 2016$; Mavukkandy et al., 2016; Gruener, 2006; Yeargin et al., 2016; Madani and Dababneh, 2016; Alhasanat et al., 2016; Elliott et al., 2016; Suarez et al., 2016; Kuli et al., 2016; Waters et al., 2016; Montgomery et al., 2016; Lamarre et al., 2016; Daud et al., 2008; Taher et al., 2008; Zulkifli et al., 2008; Pourmahmoud, 2008; Pannirselvam et al., 2008; Ng et al., 2008; El-Tous, 2008; Akhesmeh et al., 2008; Nachiengtai et al., 2008; Moezi et al., 2008; Boucetta, 2008; Darabi et al., 2008; Semin and Bakar, 2008; Al-Abbas, 2009; Abdullah et al., 2009; Abu-Ein, 2009; Opafunso et al., 2009; Semin et al., 2009 a-c; Zulkifli et al., 2009; Marzuki et al., 2015; Bier and Mostafavi, 2015; Momta et al., 2015; Farokhi and Gordini, 2015; Khalifa et al., 2015; Yang and Lin, 2015; Chang et al., 2015; Demetriou et al., 2015; Rajupillai et al., 2015; Sylvester et al., 2015; Ab-Rahman et al., 2009; Abdullah and Halim, 2009; Zotos and Costopoulos, 2009; Feraga et al., 2009; Bakar et al., 2009; Cardu et al., 2009; Bolonkin, 2009 a-b; Nandhakumar et al., 2009; Odeh et al., 2009; Lubis et al., 2009; Fathallah and Bakar, 2009; Marghany and Hashim, 2009; Kwon et al., 2010; Aly and Abuelnasr, 2010; Farahani et al., 2010; Ahmed et al., 2010; Kunanoppadon, 2010; Helmy and El-Taweel, 2010; Qutbodin, 2010; Pattanasethanon, 2010; Fen et al., 2011; Thongwan et al., 2011; Theansuwan and Triratanasirichai, 2011; Al Smadi, 2011; Tourab et al., 2011; Raptis et al., 2011; Momani et al., 2011; Ismail et al., 2011; Anizan et al., 2011; Tsolakis and Raptis, 2011; Abdullah et al., 2011; Kechiche et al., 2011; Ho et al., 2011; Rajbhandari et al., 2011; Aleksic and Lovric, 2011; Kaewnai and Wongwises, 2011; Idarwazeh, 2011; Ebrahim et al., 2012; Abdelkrim et al., 2012; Mohan et al., 2012; Abam et al., 2012; Hassan et al., 2012; Jalil and 
Sampe, 2013; Jaoude and El-Tawil, 2013; Ali and Shumaker, 2013; Zhao, 2013; El-Labban et al., 2013; Djalel et al., 2013; Nahas and Kozaitis, 2013; Petrescu and Petrescu, 2014 a-i, 2015 a-e, 2016 a-d; Fu et al., 2015; Al-Nasra et al., 2015; Amer et al., 2015; Sylvester et al., 2015b; Kumar et al., 2015; Gupta et al., 2015; Stavridou et al., 2015b; Casadei, 2015; Ge and Xu, 2015; Moretti, 2015; Wang et al., 2015; Antonescu and Petrescu, 1985; 1989; Antonescu et al., 1985a; 1985b; 1986; 1987; 1988; 1994; 1997; 2000a; 2000b; 2001; Aversa et al., 2017a; 2017b; 2017c; 2017d; 2017e; 2016a; 2016b; 2016c; 2016d; 2016e; 2016f; 2016g; 2016h; 2016i; 2016j; 2016k; 2016l; 2016m; 2016n; 2016o; Cao et al., 2013; Dong et al., 2013; Comanescu, 2010; Franklin, 1930; He et al., 2013; Lee, 2013; Lin et al., 2013; Liu et al., 2013; Padula and Perdereau, 2013; Perumaal and Jawahar, 2013; Petrescu, 2011; 2015a; 2015b; Petrescu and Petrescu, 1995a; 1995b; 1997a; 1997b; 1997c; 2000a; 2000b; 2002a; 2002b; 2003; 2005a; 2005b; 2005c; 2005d; 2005e; 2011a; 2011 b; 2012a; 2012b; 2013a; 2013b; 2013c; 2013d; 2013e; 2016a; 2016b; 2016c; Petrescu et al., 2009; 2016; 2017a; 2017b; 2017c; 2017d; 2017e; 2017f; 2017g; 2017h; 2017i; 2017j; 2017k; 2017l; 2017m; 2017n; 2017o; 2017p; 2017q; 2017r; 2017s; 2017t; 2017u; 2017v; 2017w; 2017x; 2017y; 2017z; 2017aa; 2017ab; 2017ac; 2017ad; 2017ae; 2018a; 2018b; 2018c; 2018d; 2018e; 2018f; 2018g; 2018h; 2018i; 2018j; 2018k; 2018l; 2018m; 2018n).

\section{Types of Distribution Systems}

Depending on the position and number of cams, the distribution systems can be:

- $\mathrm{OHH}$ (OverHead Valves)

- $\quad$ OHC (OverHead Camshaft)

- DOHC (Double Overhead Camshaft)

- OHV distribution system
This type of distribution system has the camshaft in the engine block. The shaft drive is usually made with a metal chain. In addition to the camshaft sprocket distribution systems, the OVH distribution also contains pushing rods (Fig. 2).
1- camshaft
2- cleats
3- pushing rods
4- rocker
5- valve spring
6- valve

The camshaft (1) is driven by the crankshaft of the engine and acts on the tillers (2). By means of pushing rods (3) the profile of the cams deflection (4) opens the valves (6). The valves are held in the seat by the helical springs (5).

\section{OHC Distribution System}

Most engines that fit modern cars are fitted with a camshaft. If each cylinder has two in take and two exhaust valves, the distribution system will have two camshafts (DOHC) (Fig. 3).

Chassis Camshaft Shaft Distribution System (DOHC):

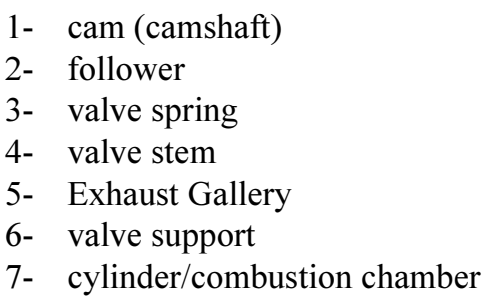

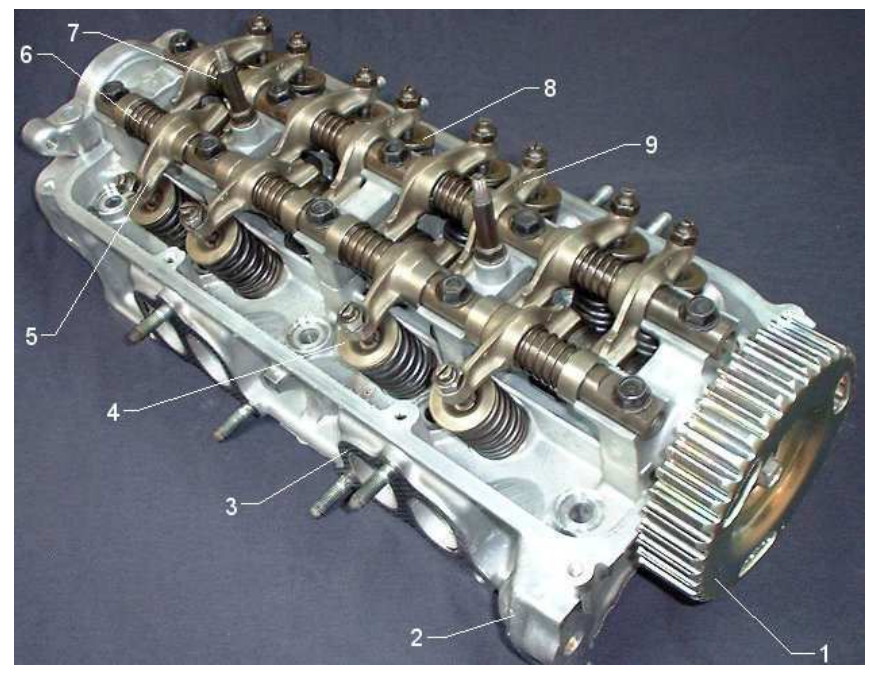

Fig. 1: Components of a modern distribution mechanism 


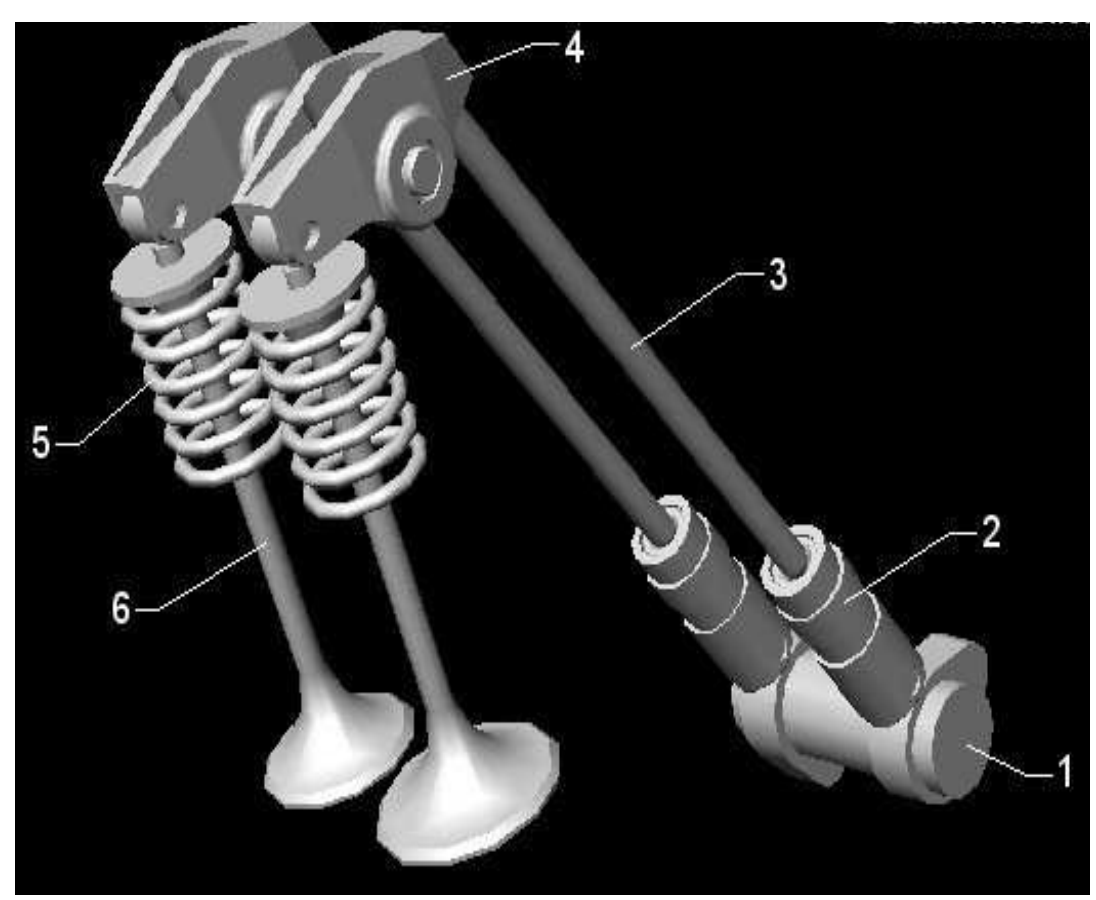

Fig. 2: Engine camshaft spline drive (OHV)

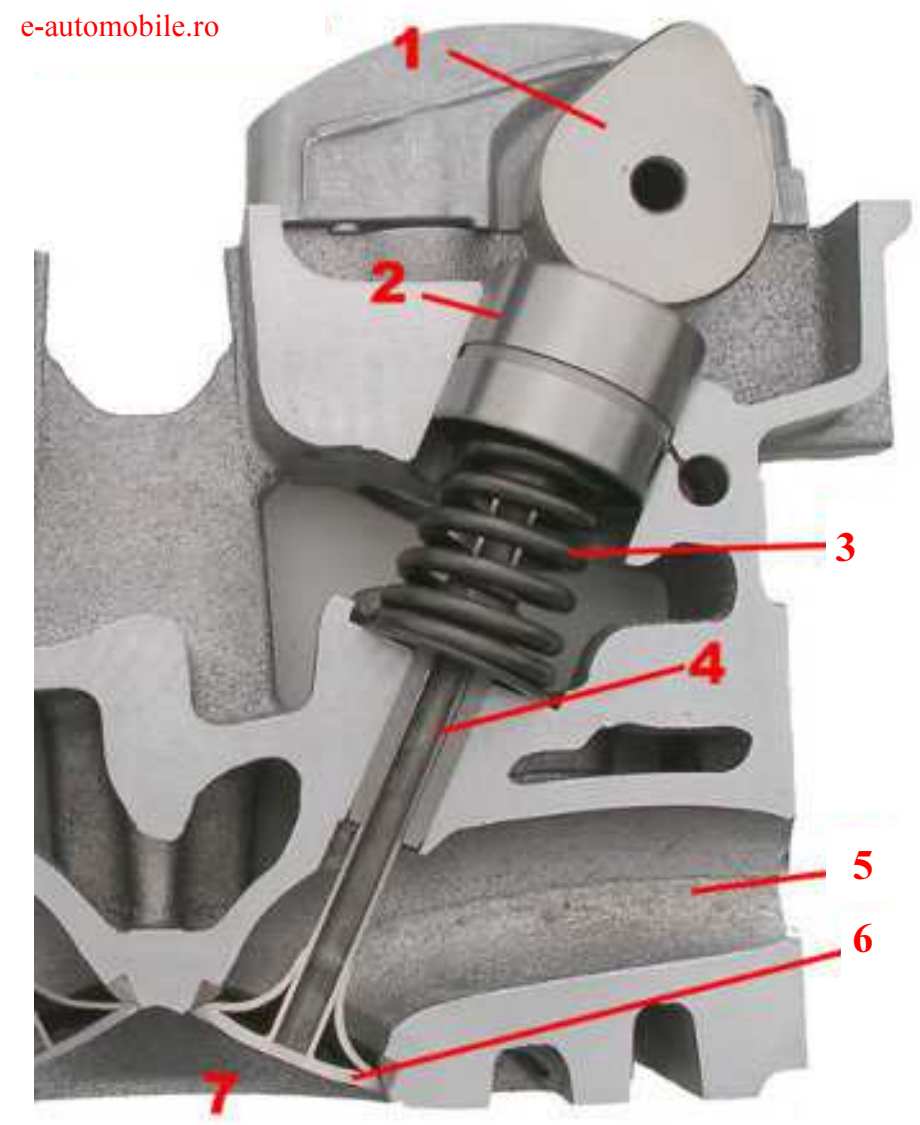

Fig. 3: Camshaft Shaft Distribution System (DOHC) 
OHC distribution systems, as compared to OHV, do not have pushing rods. Actuation of the valves is done directly by the camshaft by means of taps and coulters. If the distribution system has 4 valves per cylinder in the cylinder head, there are two camshafts acting directly on the DOHC.

The chassis camshaft $(\mathrm{OHC}, \mathrm{DOHC})$ is the number of smaller parts. The lack of pushrods and cogs increases the durability of the system, reduces vibrations and allows higher speeds.

\section{Valves}

The valve is made up of two parts, the valve stem which obstructs the channel in the cylinder head and the valve stem receiving the movement, guides the valves during the movement and evacuates some of the heat transferred to the valve (Fig. 4).

The valves open inside the cylinder to take advantage of the pressure of the gas while it is closed (better sealing). The intake valves, compared to the exhaust ports, have the larger diameter because the intake port is larger. This favors the better filling of the fresh gas cylinder during intake. In order to withstand intense mechanical and thermal stresses, the valves are made of high alloy steel.
The camshafts are driven by the crankshaft of the engine by means of a toothed belt (belt distribution) or a metal chain (chain distribution). The trees are made of alloy steel or alloy cast iron. The canvas between the cams and the sticks is always lubricated with engine oil (Fig. 5).

Because each valve opens once on a complete engine cycle (two crankshaft rotations), the camshaft speed is half that of the crankshaft.

The shape of the cams determines the length and opening height of the valves. The distribution system in which the opening height and the opening time of the valves are fixed, invariable is called a fixed distribution. A distribution system that can vary the length or the opening height of the valves is called variable distribution.

\section{Cleats}

The spool is the piece that is driven directly by the camshaft. To reduce noise in operation and to compensate for the heat play, hydraulic tightening is used. The thermal play is the distance between the moving piles of the distribution system (pushing rod-OHV or OHC camshaft), which varies depending on the temperature of the parts. The heat play increases with the wear of the parts and has a negative impact on the noise and reliability of the distribution system (Fig. 6).



Fig. 4: Valves 


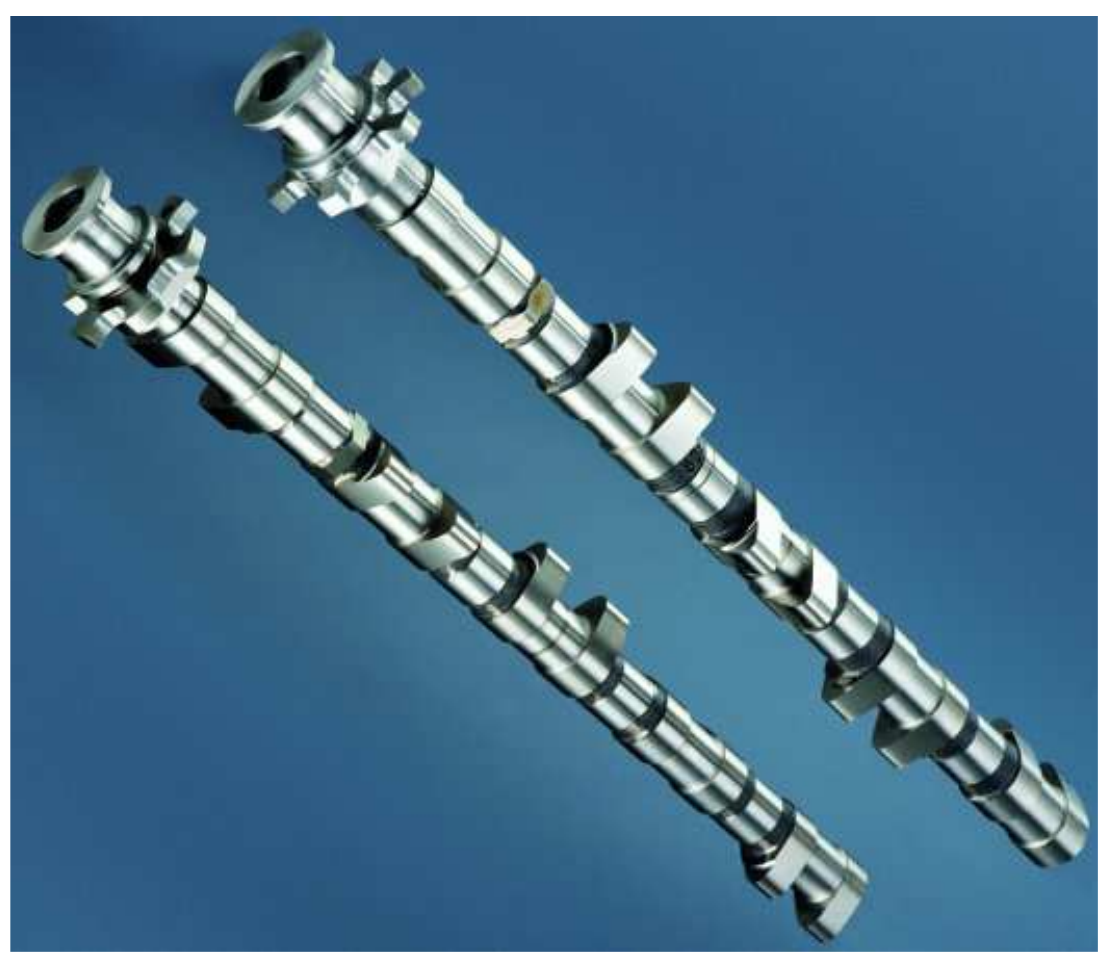

Fig. 5: Camshafts

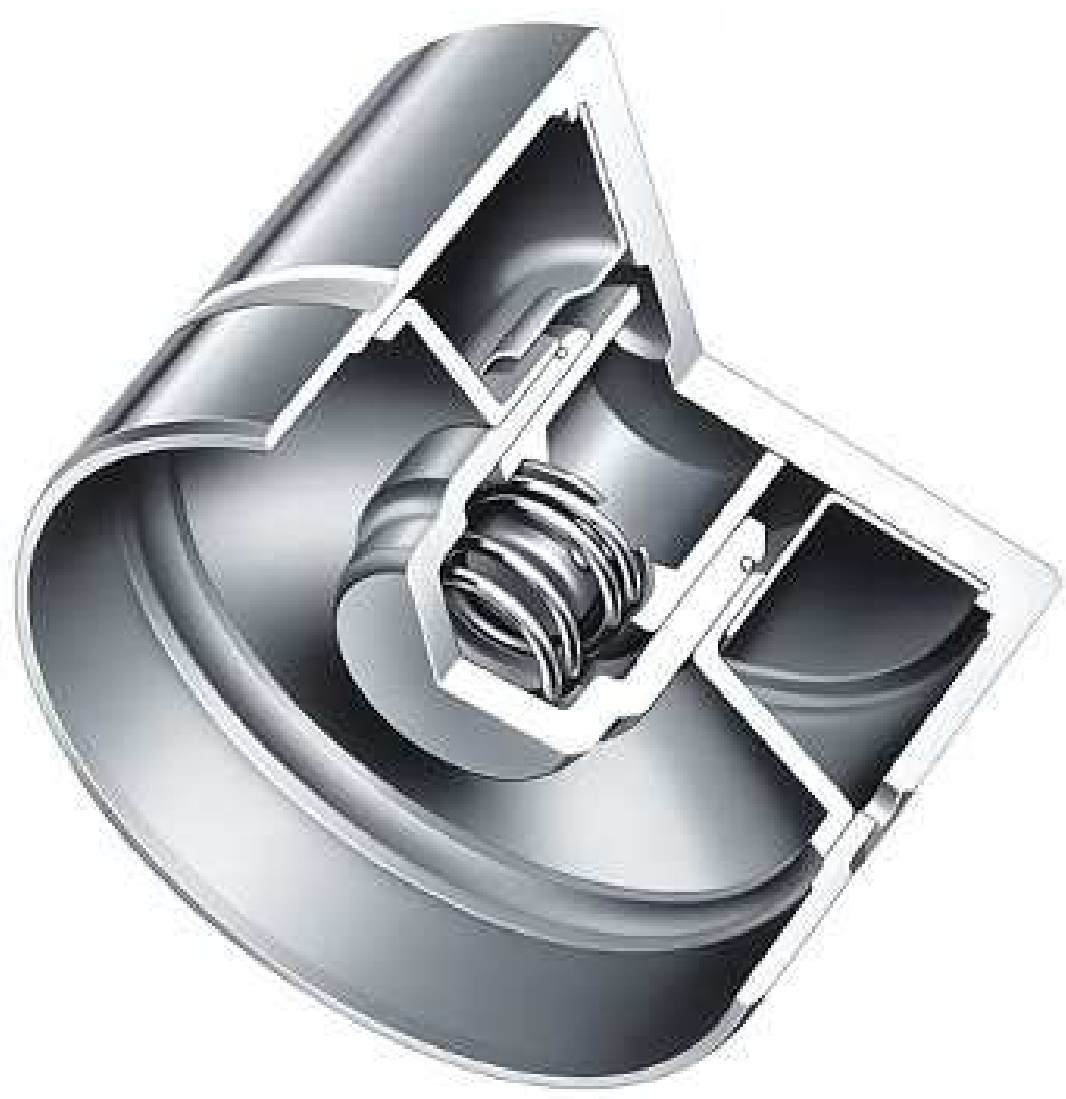

Fig. 6: Pushers 
The cam mechanisms specifically transform a uniform rotational motion into alternating non-uniform rotational motion or alternate linear motion. In these mechanisms, in general, the movement is transmitted from the cam guide member to the driven member via direct contact. It rarely happens that the cam element is a driven or fixed element. In the latter situation, the stick picks up both movements, as is the case with the mechanism that controls the vertical drift of the scissor tool sleeper: fixed cam, punch oscillating, with its rotation motion in translation.

The cam mechanisms are widespread in design mechanical engineering because the cam profile can have almost any shape, depending on the moving law that is desired for the stick.
Between the cam and the barrel, there is a superior coupling with no more than two degrees of freedom (rolling and slipping) for the case of the flat cam and no more than five degrees of freedom for the space cam case. However, there may be constraints, so that the number of degrees of freedom allowed by the kinematic couple can be reduced.

The simplest cam mechanism (Fig. 7) consists of the following kinematic elements: the cam (1), the stick (2) and the roller (3). The roll is a kinematically passive element that is introduced to reduce cam and punch wear, as well as to reduce frictional losses by turning the slip into rolling friction.



Fig. 7: The simplest cam mechanism 


\section{Materials and Methods}

In the Fig. 8 it presents the kinematics schema of the classic distribution mechanism, in two consecutive positions; with a interrupted line is represented the particular position when the follower is situated in the most down plane, $(\mathrm{s}=0)$ and the cam which has an orally rotation, with constant angular velocity, $\omega$, is situated in the point $\mathrm{A}^{0}$, (the recordation point between the base profile and the up profile, particular point that mark the up begin of the follower, imposed by the camprofile); with a continue line (green) is represented the superior couple in someone position of the up phase.

From initial position $\left(\mathrm{x}_{\mathrm{F}}\right)$ to someone position $\left(\mathrm{x}_{\mathrm{M}}\right)$ the cam (camshaft) was rotated with an $\varphi$ angle. In this time the position vector $r=r_{A}$ was rotated (in relation to the mobile axis $\mathrm{x}_{\mathrm{M}}$ ) with the $\theta$ angle, which is a sum between $\varphi$ and $\tau$ (where $\tau$ is the transmission angle who occurs between the initial, vertical, fix axis and the position vector $r=r_{A}$. The cam or camshaft movement is given by $\theta$ angle and the position vector $r$ movement is characterized by the $\theta$ angle (this is all the main problem of the classical distribution mechanism). In any position point (the contact point between cam and tappet) is given by the coordinates $r$ and $\theta$ (polar) or $\mathrm{x}_{\mathrm{A}}, \mathrm{y}_{\mathrm{A}}$ (Cartesian), for tappet in a fix system and for the cam in a mobile system.

The point $\mathrm{A}^{0}$, which marks the initial couple position, represents in the same time the contact point between the cam and follower in the first position. The cam has an angular velocity $\omega$ (the camshaft angular velocity).

Cam is rotating with the velocity $\omega$ describing the angle $\varphi$, which show how the base circle has rotated in the orally sense, (with the camshaft together); this rotation can be seen on the base circle between the two particular points, $\mathrm{A}^{0}$ and $\mathrm{A}^{0 \mathrm{i}}$.

In this time the vector $\mathrm{r}_{\mathrm{A}}=\mathrm{OA}$ (which represents the distance between the centre of cam $\mathrm{O}$ and the contact point $\mathrm{A}$ ), has rotating (trigonometric) with the $\tau$ angle. If one measures the $\theta$ angle, which positions the general vector $r_{A}$ in function of the particular vector, $r_{A 0}$, it obtains the base relation noted with (0):

$\theta=\varphi+\tau$

where, $r_{\mathrm{A}}$ is the module of the vector $\vec{r}_{A}$ and $\theta_{\mathrm{A}}$ represents the phase angle of the vector $\vec{r}_{A}$.

The rotating velocity of the vector $\vec{r}_{A}$ is $\dot{\theta}_{A}$ which it's a function of the angular velocity of the camshaft, $\omega$ and a rotating $\varphi$ angle, (by the movement laws $s(\varphi)$, $\left.\mathrm{s}^{\prime}(\varphi), \mathrm{s}^{\prime \prime}(\varphi)\right)$.

The follower isn't acted directly by the cam, by the angle, $\varphi$ and by the angular velocity $\omega$; it's acted by the vector $\vec{r}_{A}$, which has the module $\mathrm{r}_{\mathrm{A}}$, the position angle $\theta_{\mathrm{A}}$ and the angular velocity $\dot{\theta}_{A}$. From here result a particular (dynamic) kinematics, the classical kinematics being just a static and approximate kinematics.

Kinematics one defines the next velocities (Fig. 8).

$\vec{v}_{1}=$ the cam velocity; which is the velocity of the vector $\vec{r}_{A}$, in the point A (that is not a fix point on the cam, but it is a point which is moving on the cam); now the classical relation (1) become an approximately relation and the real relation takes the form (2):

$$
\begin{aligned}
& v_{1}=r_{A} \cdot \omega \\
& v_{1}=r_{A} \cdot \dot{\theta}_{A}
\end{aligned}
$$

The velocity $\vec{v}_{1}=A C$ is separating in the velocity $\vec{v}_{2}=B C$ (the follower velocity which act in its axe, on a vertical direction) and $\vec{v}_{12}=A B$ (the slide velocity between the two profiles, the sliding velocity between the cam and the follower, which works by the direction of the commune tangent line of the two profiles in the contact point).

Usually the cam profile is synthesis with the $\mathrm{AD}=\mathrm{s}$ ' known, for the classical module $C$ and one can write the relations (3-7):

$$
\begin{aligned}
& r_{A}^{2}=\left(r_{0}+s\right)^{2}+s^{\prime 2} \\
& r_{A}=\sqrt{\left(r_{0}+s\right)^{2}+s^{\prime 2}} \\
& \cos \tau=\frac{r_{0}+s}{r_{A}}=\frac{r_{0}+s}{\sqrt{\left(r_{0}+s\right)^{2}+s^{\prime 2}}} \\
& \sin \tau=\frac{A D}{r_{A}}=\frac{s^{\prime}}{r_{A}}=\frac{s^{\prime}}{\sqrt{\left(r_{0}+s\right)^{2}+s^{\prime 2}}} \\
& v_{2}=v_{1} \cdot \sin \tau=r_{A} \cdot \dot{\theta}_{A} \cdot \frac{s^{\prime}}{r_{A}}=s^{\prime} \cdot \dot{\theta}_{A}
\end{aligned}
$$

Now, the follower velocity isn't $\dot{s}\left(v_{2} \neq \dot{s} \equiv s^{\prime} \cdot \omega\right)$, but it's given by the relation (9). At the classical distribution mechanism the transmitting function $\mathrm{D}$, is given by the relations (8):

$$
\begin{aligned}
& \left\{\begin{array}{l}
\dot{\theta}_{A}=D \cdot \omega \\
D=\frac{\dot{\theta}_{A}}{\omega}=\frac{v_{2}}{\dot{s}}
\end{array}\right. \\
& v_{2}=s^{\prime} \cdot \dot{\theta}_{A}=s^{\prime} \cdot D \cdot \omega=\dot{s} \cdot D
\end{aligned}
$$


Determination of the sliding velocity between the two profiles in contact is made by the relation (10):

$$
\left\{\begin{array}{l}
v_{12}=v_{1} \cdot \cos \tau= \\
=r_{A} \cdot \dot{\theta}_{A} \cdot \frac{r_{0}+s}{r_{A}}=\left(r_{0}+s\right) \cdot \dot{\theta}_{A}
\end{array}\right.
$$

The angles $\tau$ (and then $\theta_{A}$ ) will be determined with its first and second derivatives.

The $\tau$ angle has been determined from the triangle ODA (Fig. 8) with the relations (11-13):

$$
\begin{aligned}
& \sin \tau=\frac{s^{\prime}}{\sqrt{\left(r_{0}+s\right)^{2}+s^{\prime 2}}} \\
& \cos \tau=\frac{r_{0}+s}{\sqrt{\left(r_{0}+s\right)^{2}+s^{\prime 2}}} \\
& \operatorname{tg} \tau=\frac{s^{\prime}}{r_{0}+s}
\end{aligned}
$$

One derives relation (11) in function of $\varphi$ angle and it obtains the expression (14):

$$
\tau^{\prime} \cdot \cos \tau=\frac{s^{\prime \prime} \cdot r_{A}-s^{\prime} \cdot \frac{\left(r_{0}+s\right) \cdot s^{\prime}+s^{\prime} \cdot s^{\prime \prime}}{r_{A}}}{\left(r_{0}+s\right)^{2}+s^{\prime 2}}
$$

The relation (14) will be written in the form (15):

$$
\left\{\begin{array}{l}
\tau^{\prime} \cdot \cos \tau= \\
=\frac{s^{\prime \prime} \cdot\left(r_{0}+s\right)^{2}+s^{\prime \prime} \cdot s^{\prime 2}-s^{\prime 2} \cdot\left(r_{0}+s\right)-s^{\prime 2} \cdot s^{\prime \prime}}{\left[\left(r_{0}+s\right)^{2}+s^{\prime 2}\right] \cdot \sqrt{\left(r_{0}+s\right)^{2}+s^{\prime 2}}}
\end{array}\right.
$$

From the relation (12) one extracts the value of cos $\tau$, which will be introduced in the left term of the expression (15); then one reduces $\mathrm{s}^{\text {" }} . \mathrm{s}^{2}$ from the right term of the expression (15) and it obtains the relation (16):

$$
\left\{\begin{array}{l}
\tau^{\prime} \cdot \frac{r_{0}+s}{\sqrt{\left(r_{0}+s\right)^{2}+s^{\prime 2}}} \\
=\frac{\left(r_{0}+s\right) \cdot\left[s^{\prime \prime} \cdot\left(r_{0}+s\right)-s^{\prime 2}\right]}{\left[\left(r_{0}+s\right)^{2}+s^{\prime 2}\right] \cdot \sqrt{\left(r_{0}+s\right)^{2}+s^{\prime 2}}}
\end{array}\right.
$$

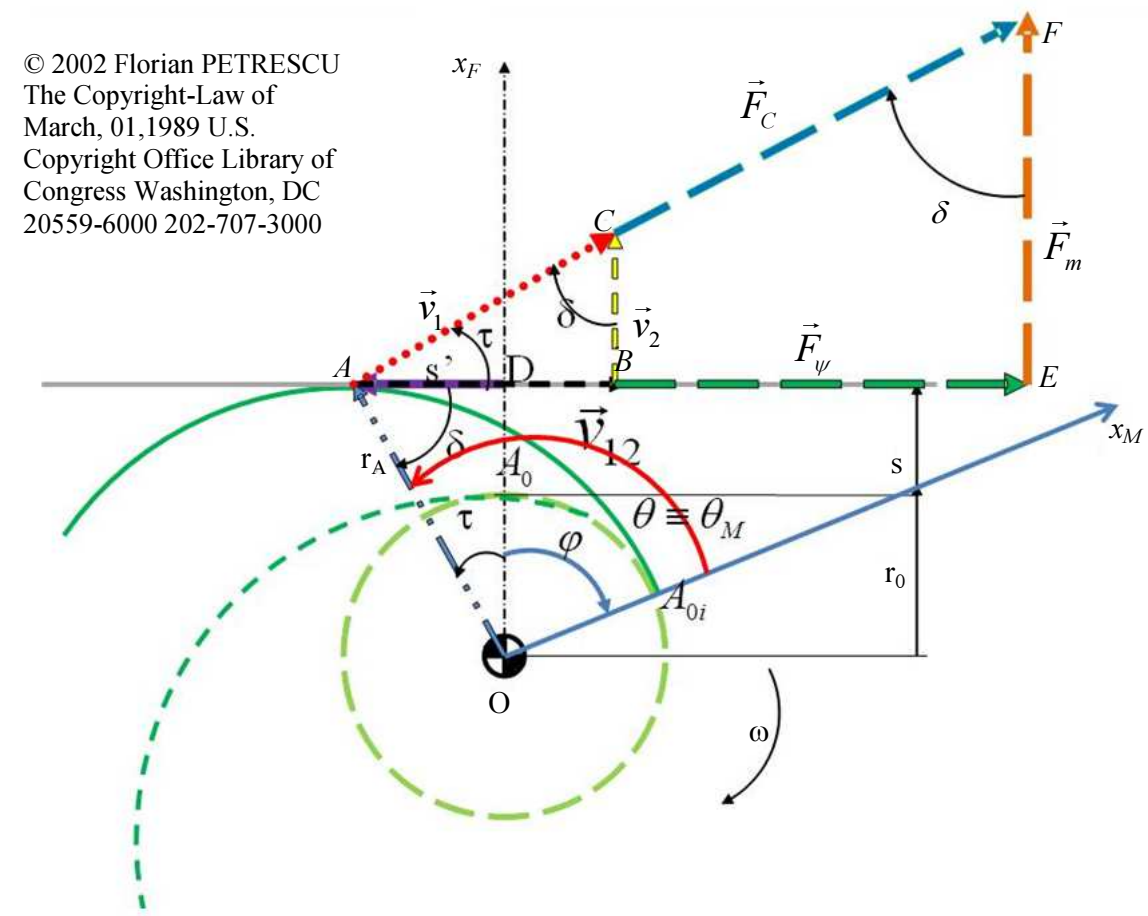

Fig. 8: Mechanism with rotating cam and plane translating tappet 
After some simplifications one obtains finally the relation (17) which represents the expression of $\tau^{\prime}$ :

$\tau^{\prime}=\frac{s^{\prime \prime} \cdot\left(r_{0}+s\right)-s^{\prime 2}}{\left(r_{0}+s\right)^{2}+s^{\prime 2}}$

Now, when it was explicitly $\tau$ ', one can determine the next derivatives. The expression (17) will be derived directly and it can be obtained for begin the relation (18):

$$
\begin{aligned}
& \tau "= \\
& {\left[s^{\prime \prime \prime}\left(r_{0}+s\right)+s^{\prime \prime} s^{\prime}-2 s^{\prime} s^{\prime \prime}\right]\left[\left(r_{0}+s\right)^{2}\right.} \\
& \frac{\left.+s^{\prime 2}\right]-2\left[s^{\prime \prime}\left(r_{0}+s\right)-s^{\prime 2}\right]\left[\left(r_{0}+s\right) s^{\prime}+s^{\prime} s^{\prime \prime}\right]}{\left[\left(r_{0}+s\right)^{2}+s^{\prime 2}\right]^{2}}
\end{aligned}
$$

One reduces the terms from the first bracket of the numerator (s'.s"') and then one draws out s' from the fourth bracket of the numerator and one obtains the expression (19):

$$
\begin{aligned}
& \tau "= \\
& {\left[s^{\prime \prime \prime} \cdot\left(r_{0}+s\right)-s^{\prime} . s^{\prime \prime}\right] \cdot\left[\left(r_{0}+s\right)^{2}+s^{\prime 2}\right]} \\
& \frac{-2 \cdot s^{\prime} \cdot\left[s^{\prime \prime} .\left(r_{0}+s\right)-s^{\prime 2}\right] \cdot\left[r_{0}+s+s^{\prime \prime}\right]}{\left[\left(r_{0}+s\right)^{2}+s^{\prime 2}\right]^{2}}
\end{aligned}
$$

Now, one can calculate $\theta_{\mathrm{A}}$, with its first two derivatives, $\dot{\theta}_{A}$ and $\ddot{\theta}_{A}$. We write $\theta$ and not $\theta_{\mathrm{A}}$, to simplify the notation. Now, one can determine (20), or relation $(0)$ :

$$
\theta=\tau+\phi
$$

One derives (20) and it obtains the relation (21):

$$
\dot{\theta}=\dot{\tau}+\dot{\phi}=\tau^{\prime} \cdot \omega+\omega=\omega \cdot\left(1+\tau^{\prime}\right)=D \cdot \omega
$$

One makes the second derivative of (20) and the first derivative of (21) and it obtains (22):

$$
\ddot{\theta}=\ddot{\tau}+\ddot{\phi}=\tau^{\prime \prime} \cdot \omega^{2}=D^{\prime} \cdot \omega^{2}
$$

One can write now the transmitting functions, $D$ and $D^{\prime}$ (at the classical module C), in the forms (23-24):

$$
\begin{aligned}
& D=\tau^{\prime}+1 \\
& D^{\prime}=\tau^{\prime \prime}
\end{aligned}
$$

The follower velocity (relations from system 25), need the expression of the transmitted function, D:

$$
v_{2}=s^{\prime} \cdot w=s^{\prime} \cdot \dot{\theta}_{A}=s^{\prime} \cdot \dot{\theta}=s^{\prime} \cdot D \cdot \omega=\dot{s} \cdot D
$$

Where:

$w=D \cdot \omega$

For the classical distribution mechanism (Module C), the variable $w$ is the same with $\dot{\theta}_{A}$ (see the relation 25). But at the $B$ and $F$ modules (at the cam gears where the follower has roll), the transmitted function $D$ (and $w$ ), takes some complex forms.

Now, it can determine the acceleration of the follower (27):

$\ddot{y} \equiv a_{2}=\left(s^{\prime \prime} \cdot D+s^{\prime} \cdot D^{\prime}\right) \cdot \omega^{2}$

In the Fig. 9, it can be seen the kinematics classic and dynamic; the velocities (a) and the accelerations (b).

To determine the acceleration of the follower, are necessary s' and s', D and D', $\tau$ ' and $\tau$ ',

The kinematics dynamic diagrams of $\mathrm{v}_{2}$ (obtained with relation 25, Fig. 9a) and $a_{2}$ (obtained with relation 27 , Fig. 9b), have more a dynamic aspect than a kinematic one. It has used the movement law SINE, a rotation velocity at the crankshaft, $\mathrm{n}=5500$ [rpm], an up angle, $\varphi_{\mathrm{u}}=75$ [deg], a down angle $\varphi_{\mathrm{d}}=75$ [deg] (identically with the up angle), a ray at the basic circle of the cam, $\mathrm{r}_{0}=17[\mathrm{~mm}]$ and a maxim stroke of the follower, $\mathrm{h}_{\mathrm{T}}=6[\mathrm{~mm}]$. Anyway, the dynamic is more complex, having in view the masses and the inertia moments, the resistant and motor forces, the elasticity constants and the amortization coefficient of the kinematics chain, the inertia forces of the system, the rotation velocity of the camshaft and the variation of the camshaft velocity, $\omega$ with the cam $\varphi$ position and with the rotation speed of the crankshaft, $n$.

\section{Plotting (Synthesis) of Classical Cam Profile}

In $\mathrm{xOy}$ fixed system, Cartesian coordinates of point A of contact (of the tappet 2) are given by the position vector $\mathrm{r}_{\mathrm{A}}$ projections on the axes $\mathrm{Ox} \mathrm{Oy}$ respectively and analytical expressions expressed by the relational system (28):

$$
\left\{\begin{array}{l}
x_{T}=r_{A} \cdot \cos \left(\phi+\tau+\frac{\pi}{2}-\phi\right)=r_{A} \cdot \cos \left(\frac{\pi}{2}+\tau\right) \\
=-r_{A} \cdot \sin \tau=-r_{A} \cdot \frac{s^{\prime}}{r_{A}}=-s^{\prime} \\
y_{T}=r_{A} \cdot \sin \left(\phi+\tau+\frac{\pi}{2}-\phi\right)=r_{A} \cdot \sin \left(\frac{\pi}{2}+\tau\right) \\
=r_{A} \cdot \cos \tau=r_{A} \cdot \frac{r_{0}+s}{r_{A}}=r_{0}+s
\end{array}\right.
$$




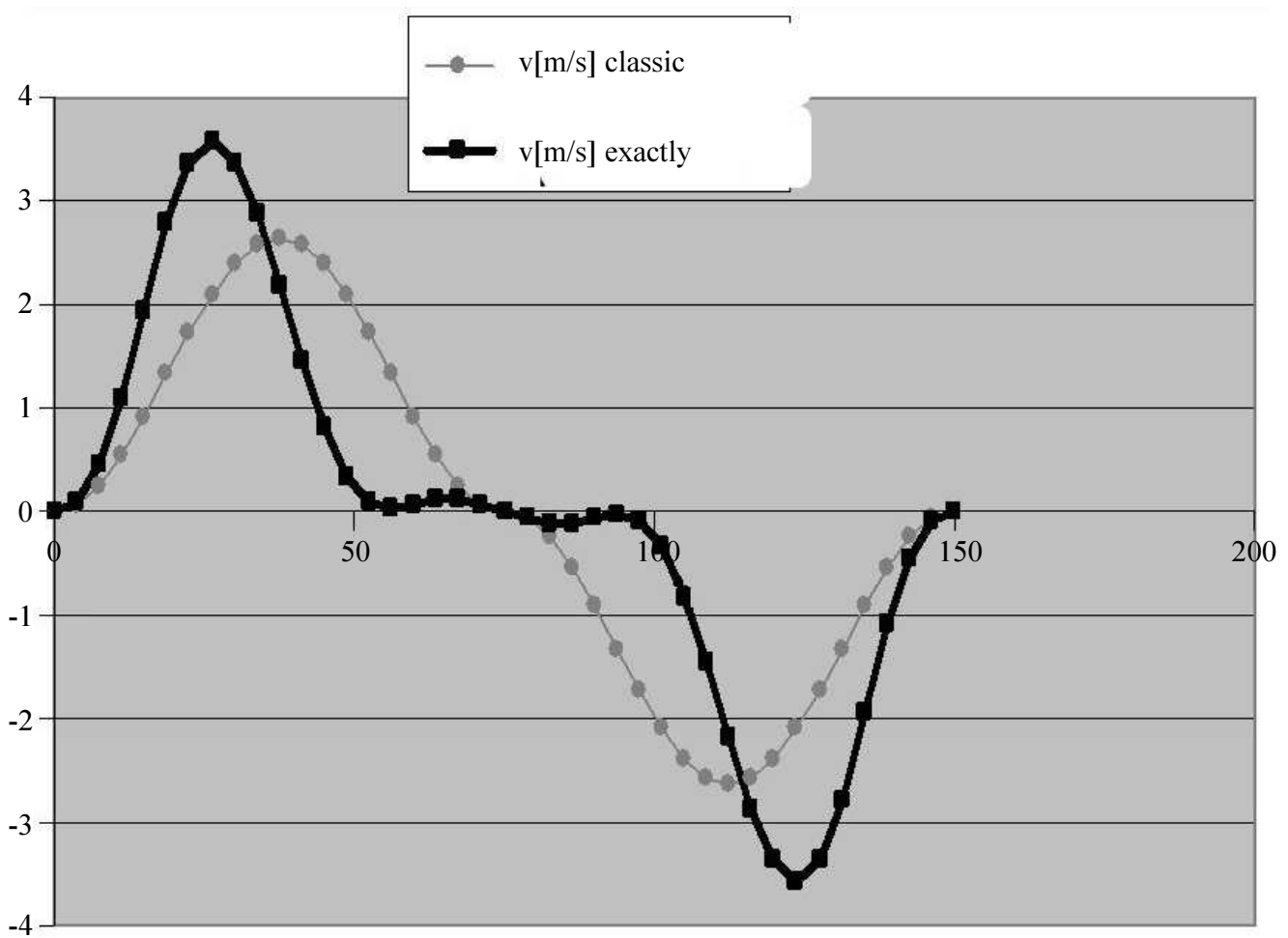

(a)

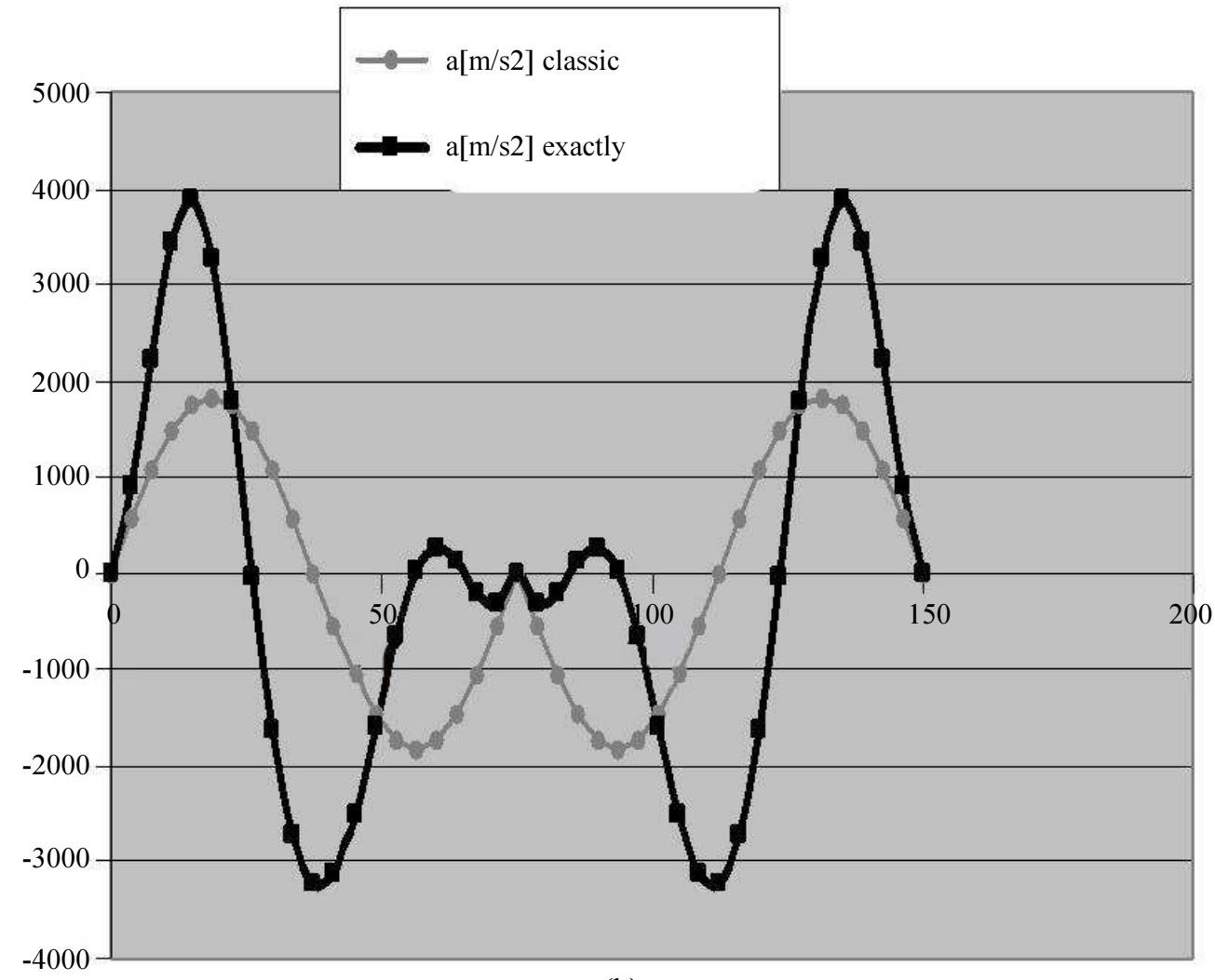

(b)

Fig. 9: The classical and dynamic (exactly) kinematics (a) Velocities (b) Accelerations of the follower 




Fig. 10: A cosine profile of a normal classical cam

In the mobile system x'Oy' a Cartesian coordinates of the point contact $\mathrm{A}$ (belonging to the cam profile which rotated clockwise by angle $\varphi$ ) are given by the relations systems (29-30):

$$
\begin{aligned}
& \left\{\begin{array}{l}
x_{C}=r_{A} \cdot \cos \left(\phi+\tau+\frac{\pi}{2}-\phi+\phi\right)=r_{A} \cdot \cos \left(\frac{\pi}{2}+\tau+\phi\right) \\
=r_{A} \cdot \sin (-\phi-\tau)=-r_{A} \cdot \sin (\phi+\tau) \\
=-r_{A} \cdot(\sin \phi \cdot \cos \tau+\sin \tau \cdot \cos \phi) \\
=-r_{A} \cdot \frac{r_{0}+s}{r_{A}} \cdot \sin \phi-r_{A} \cdot \frac{s^{\prime}}{r_{A}} \cdot \cos \phi \\
=-\left(r_{0}+s\right) \cdot \sin \phi-s^{\prime} \cdot \cos \phi \\
y_{C}=r_{A} \cdot \sin \left(\phi+\tau+\frac{\pi}{2}-\phi+\phi\right)=r_{A} \cdot \sin \left(\frac{\pi}{2}+\tau+\phi\right) \\
=r_{A} \cdot \cos (-\phi-\tau)=r_{A} \cdot \cos (\phi+\tau) \\
=r_{A} \cdot(\cos \phi \cdot \cos \tau-\sin \tau \cdot \sin \phi) \\
=r_{A} \cdot \frac{r_{0}+s}{r_{A}} \cdot \cos \phi-r_{A} \cdot \frac{s^{\prime}}{r_{A}} \cdot \sin \phi=\left(r_{0}+s\right) \cdot \cos \phi-s^{\prime} \cdot \sin \phi
\end{array}\right. \\
& \left\{\begin{array}{l}
x_{C}=-s^{\prime} \cdot \cos \phi-\left(r_{0}+s\right) \cdot \sin \phi \\
y_{C}=\left(r_{0}+s\right) \cdot \cos \phi-s^{\prime} \cdot \sin \phi
\end{array}\right.
\end{aligned}
$$

Above, in the Fig. 10 it can be seen the cam profile to the classical module $\mathrm{C}$, for a law cosine, $\mathrm{h}=6[\mathrm{~mm}], \mathrm{r}_{0}=$ $13[\mathrm{~mm}], \eta=6 \%$.

\section{Results}

In the Fig. 11 one can see the module B, with rotation cam and translated tappet with roll, in initial position and in some one position. The $\alpha_{0}$ angle defines the base position of the vector $\bar{r}_{B 0}$ in $\mathrm{OCB}_{0}$ right triangle so that it can be written Equation 2.1-2.4: $0 \mathrm{Br}$

$$
\begin{aligned}
& r_{B_{0}}=r_{0}+r_{b} \\
& s_{0}=\sqrt{r_{B_{0}}^{2}-e^{2}} \\
& \cos \alpha_{0}=\frac{e}{r_{B_{0}}} \\
& \sin \alpha_{0}=\frac{S_{0}}{r_{B_{0}}}
\end{aligned}
$$

The $\delta$ pressure angle (that occurs between normal $\mathrm{n}$ gone through the contact point $\mathrm{A}$ and a vertical line) has the known size given by the relations (2.5-2.7):

$$
\begin{aligned}
& \cos \delta=\frac{s_{0}+s}{\sqrt{\left(s_{0}+s\right)^{2}+\left(s^{\prime}-e\right)^{2}}} \\
& \sin \delta=\frac{s^{\prime}-e}{\sqrt{\left(s_{0}+s\right)^{2}+\left(s^{\prime}-e\right)^{2}}}
\end{aligned}
$$




$$
\operatorname{tg} \delta=\frac{s^{\prime}-e}{s_{0}+s}
$$

The vector $\bar{r}_{A}$ can be determined directly with the relations $(2.8-2.9)$ :

$$
\begin{aligned}
& r_{A}^{2}=\left(e+r_{b} \cdot \sin \delta\right)^{2}+\left(s_{0}+s-r_{b} \cdot \cos \delta\right)^{2} \\
& r_{A}=\sqrt{\left(e+r_{b} \cdot \sin \delta\right)^{2}+\left(s_{0}+s-r_{b} \cdot \cos \delta\right)^{2}}
\end{aligned}
$$

It can directly determine the angle $\alpha_{A}(2.10-2.11)$ :

$$
\begin{aligned}
& \cos \alpha_{A}=\frac{e+r_{b} \cdot \sin \delta}{r_{A}} \\
& \sin \alpha_{A}=\frac{s_{0}+s-r_{b} \cdot \cos \delta}{r_{A}}
\end{aligned}
$$

It can be now drawn directly the cam profile using polar coordinates $r_{A}$ (known, see relation 2.9) and $\theta_{A}$ (which is determined by relations 2.12-2.17):

$$
\begin{aligned}
& \gamma=\alpha_{A}-\alpha_{0} \\
& \cos \gamma=\cos \alpha_{A} \cdot \cos \alpha_{0}+\sin \alpha_{A} \cdot \sin \alpha_{0} \rightarrow
\end{aligned}
$$

$$
\begin{aligned}
& \sin \gamma=\sin \alpha_{A} \cdot \cos \alpha_{0}-\cos \alpha_{A} \cdot \sin \alpha_{0} \\
& \theta_{A}=\phi-\gamma \\
& \cos \theta_{A}=\cos \phi \cdot \cos \gamma+\sin \phi \cdot \sin \gamma \\
& \sin \theta_{A}=\sin \phi \cdot \cos \gamma-\sin \gamma \cdot \cos \phi
\end{aligned}
$$

In the Fig. 12 it can be seen for the module B a cosine law cam profile calculated with parameters: $r_{0}=13$ [mm], $r_{b}=2[\mathrm{~mm}], h=20[\mathrm{~mm}], \varphi_{u}=60$ [deg]. One has obtained in this mode a high yield for a mechanism with cam: $\eta=39 \%$. It can be obtained the same yield (Fig. 13) with decreased stroke and up angle: $r_{0}=13[\mathrm{~mm}], r_{b}$ $=2[\mathrm{~mm}], h=13[\mathrm{~mm}], \varphi_{u}=45[\mathrm{deg}], \eta=39 \%$.

For such distribution mechanism works normally we must use the special adjustment valve spring: $x_{0}=9[\mathrm{~cm}], k$ $=500000[\mathrm{~N} / \mathrm{m}]$. Where $\mathrm{k}$ is the valve spring elastic coefficient and $\mathrm{x}_{0}$ is the valve spring preload. It can be obtained a higher yield (Fig. 14) with the next parameters: $r_{0}=15[\mathrm{~mm}], r_{b}=2[\mathrm{~mm}], h=10[\mathrm{~mm}], \varphi_{\mathrm{u}}=30$ [deg], $\eta=$ $43 \%, k=1500000[\mathrm{~N} / \mathrm{m}], x_{0}=5[\mathrm{~cm}]$. Although spring used is extremely hard to have a good dynamic in operation (Fig. 15), there's need to reduce its camshaft rotation speed three times. But for such distribution mechanism may work must be used a triple cam.



Fig. 11: Cam module B, with translated tappet with roll 


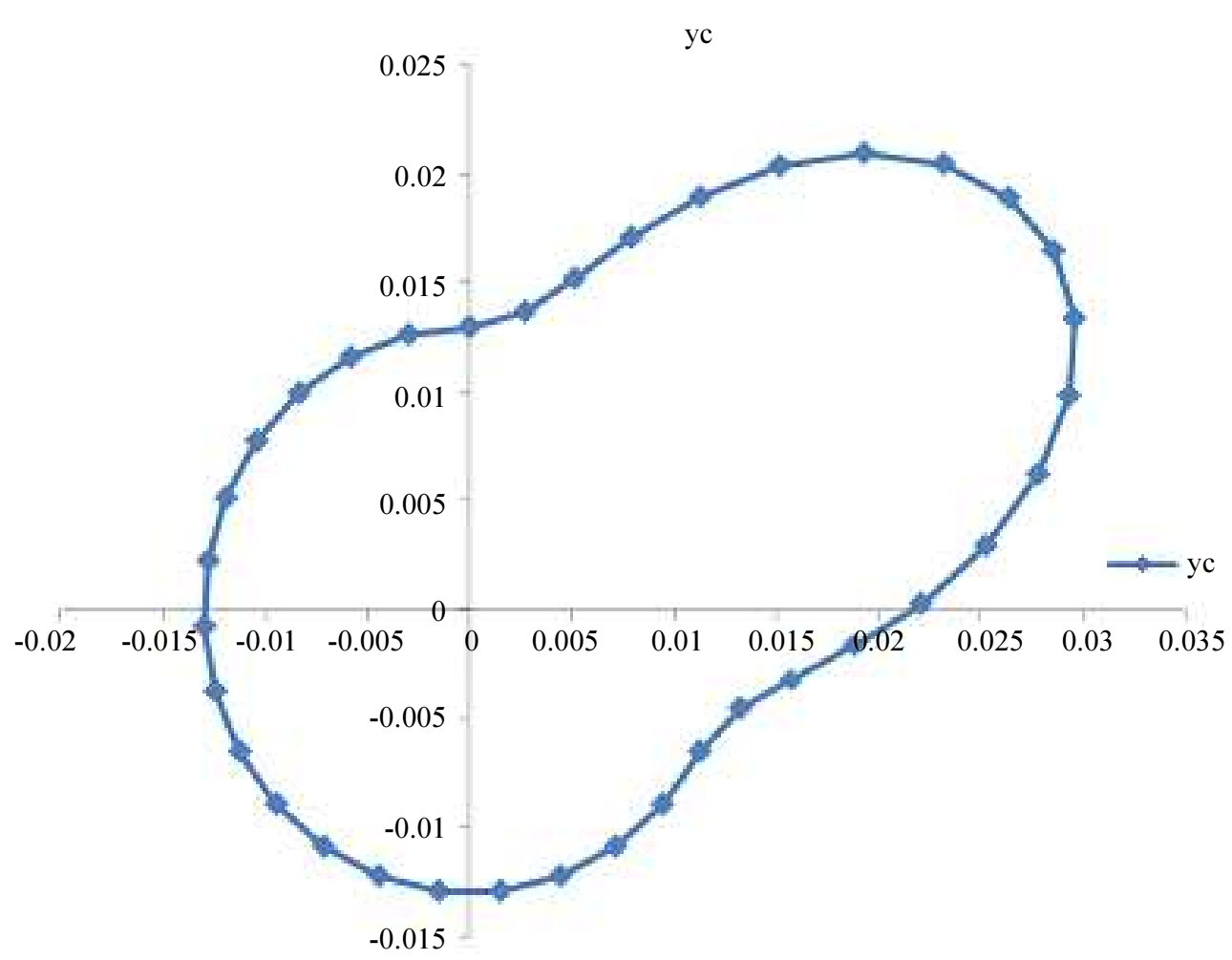

Fig. 12: Cam module B profile cosine law, with translated tappet with roll; $r_{0}=13[\mathrm{~mm}], \mathrm{r}_{\mathrm{b}}=2[\mathrm{~mm}], \mathrm{h}=20[\mathrm{~mm}], \varphi_{\mathrm{u}}=60$ [deg], $\eta=39 \%$

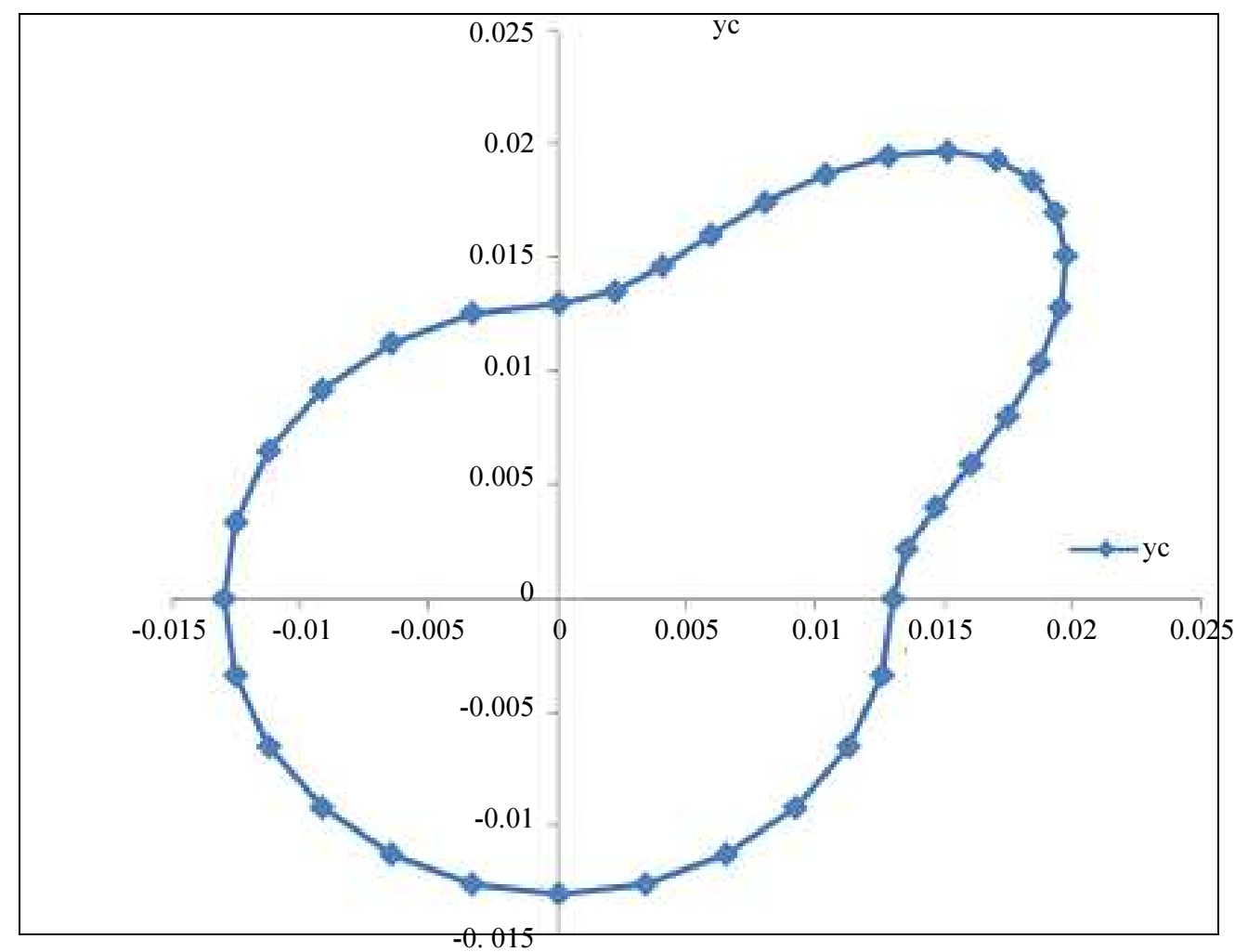

Fig. 13: Cam module B profile cosine law, with translated tappet with roll; $r_{0}=13[\mathrm{~mm}], r_{b}=2[\mathrm{~mm}], h=13[\mathrm{~mm}], \varphi \mathrm{u}=45[\mathrm{deg}], \eta=39 \%$ 


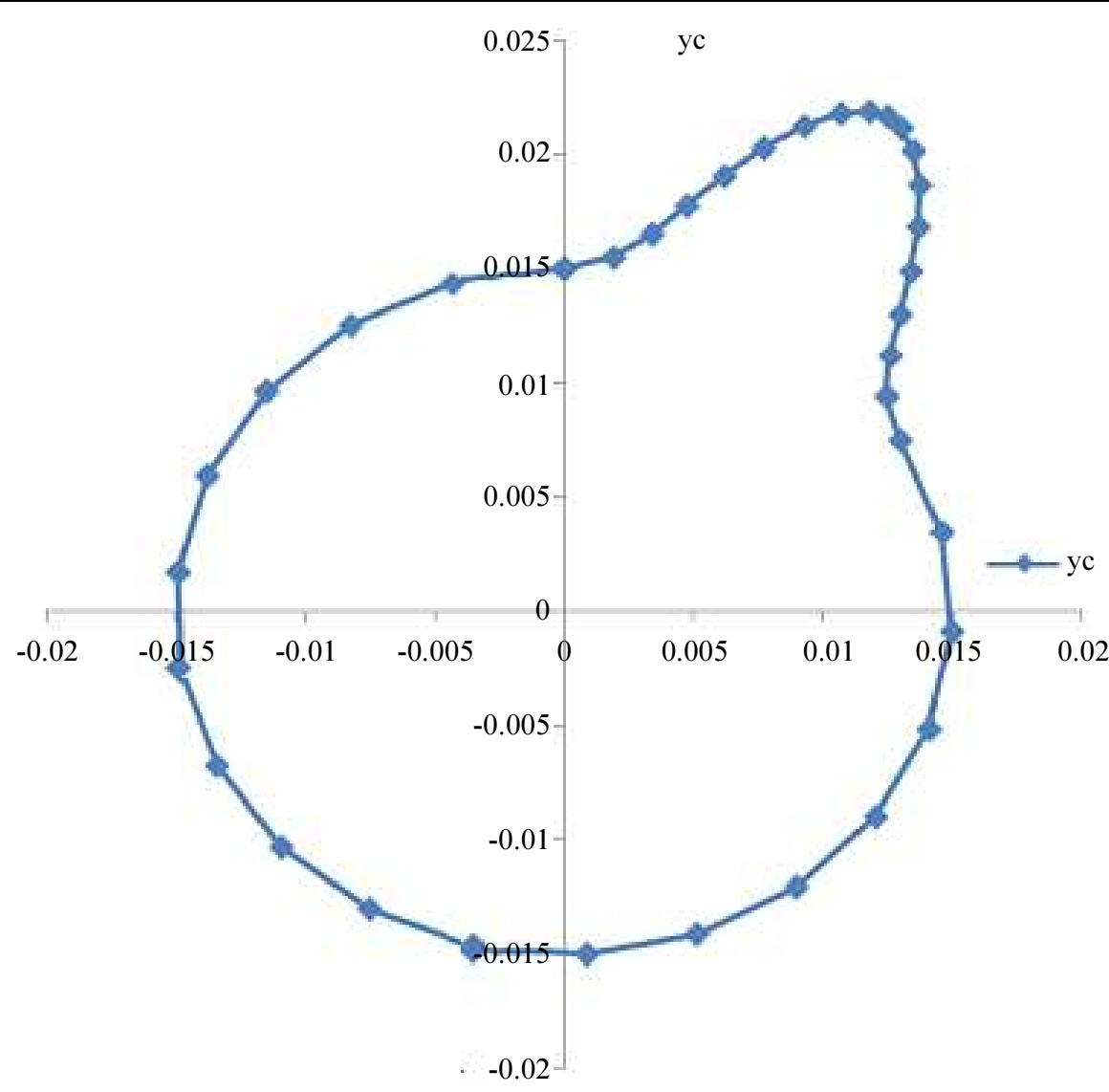

Fig. 14: Cam module B profile cosine law, with translated tappet with roll; $r_{0}=15[\mathrm{~mm}], \mathrm{r}_{\mathrm{b}}=2[\mathrm{~mm}], \mathrm{h}=10[\mathrm{~mm}], \varphi_{\mathrm{u}}=30[\mathrm{deg}], \eta=43 \%$

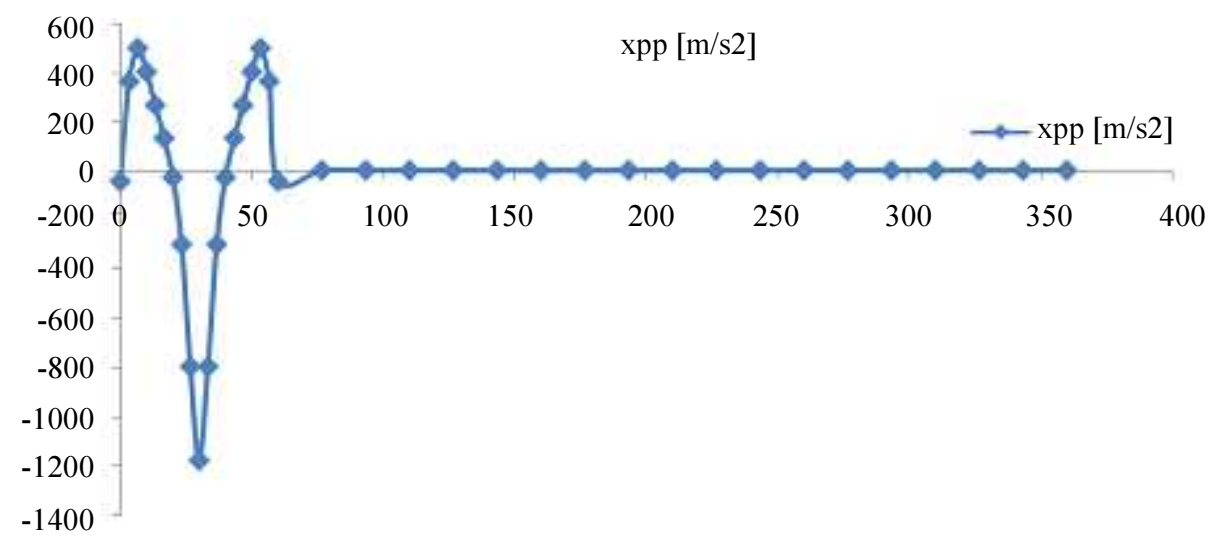

Fig. 15: Cam module B dynamics (cosine law, with translated tappet with roll: $\mathrm{r}_{0}=15[\mathrm{~mm}], \mathrm{r}_{\mathrm{b}}=2[\mathrm{~mm}], \mathrm{h}=10[\mathrm{~mm}], \varphi_{\mathrm{u}}=30$ [deg], $\eta=43 \%$ ); the tappet acceleration in relation of $\varphi$ angle

\section{Exact Kinematics Module B}

For determination of exact kinematics one uses the next relations (2.18-2.45):

$r_{B}^{2}=e^{2}+\left(s_{0}+s\right)^{2}$

$r_{B}=\sqrt{r_{B}^{2}}$

$$
\cos \alpha_{B} \equiv \sin \tau=\frac{e}{r_{B}}
$$

$\sin \alpha_{B} \equiv \cos \tau=\frac{s_{0}+s}{r_{B}}$

$\cos (\delta+\tau)=\cos \delta \cdot \cos \tau-\sin \delta \cdot \sin \tau$ 


$$
\begin{aligned}
& r_{A}^{2}=r_{B}^{2}+r_{b}^{2}-2 \cdot r_{b} \cdot r_{B} \cdot \cos (\delta+\tau) \\
& \cos \mu=\frac{r_{A}^{2}+r_{B}^{2}-r_{b}^{2}}{2 \cdot r_{A} \cdot r_{B}}
\end{aligned}
$$

$\sin (\delta+\tau)=\sin \delta \cdot \cos \tau+\sin \tau \cdot \cos \delta$

$\sin \mu=\frac{r_{b}}{r_{A}} \cdot \sin (\delta+\tau)$

$\alpha_{A}=\alpha_{B}-\mu$

$\dot{\alpha}_{A}=\dot{\alpha}_{B}-\dot{\mu}$

$-\sin \alpha_{B} \cdot \dot{\alpha}_{B}=-\frac{e \cdot \dot{r}_{B}}{r_{B}^{2}}$

$\dot{\alpha}_{B}=\frac{e \cdot r_{B} \cdot \dot{r}_{B}}{\left(s_{0}+s\right) \cdot r_{B}^{2}}$

$\left\{\begin{array}{l}2 \cdot r_{B} \cdot \dot{r}_{B}=2 \cdot\left(s_{0}+s\right) \cdot \dot{s} \\ r_{B} \cdot \dot{r}_{B}=\left(s_{0}+s\right) \cdot \dot{s}\end{array}\right.$

$\dot{\alpha}_{B}=\frac{e \cdot\left(s_{0}+s\right) \cdot \dot{s}}{\left(s_{0}+s\right) \cdot r_{B}^{2}}=\frac{e \cdot \dot{s}}{r_{B}^{2}}$

$\left\{\begin{array}{l}2 \cdot \dot{r}_{A} \cdot r_{B} \cdot \cos \mu+2 \cdot r_{A} \cdot \dot{r}_{B} \cdot \cos \mu \\ -2 \cdot r_{A} \cdot r_{B} \cdot \sin \mu \cdot \dot{\mu}=2 \cdot r_{A} \cdot \dot{r}_{A}+2 \cdot r_{B} \cdot \dot{r}_{B}\end{array}\right.$

$\left\{\begin{array}{l}2 \cdot r_{A} \cdot \dot{r}_{A}=2 \cdot r_{B} \cdot \dot{r}_{B}-2 \cdot r_{b} \cdot \dot{r}_{B} \cdot \cos (\delta+\tau) \\ +2 \cdot r_{b} \cdot r_{B} \cdot \sin (\delta+\tau) \cdot(\dot{\delta}+\dot{\tau})\end{array}\right.$

$\delta^{\prime}=\frac{s^{\prime \prime} \cdot\left(s_{0}+e\right)-s^{\prime} \cdot\left(s^{\prime}-e\right)}{\left(s_{0}+s\right)^{2}+\left(s^{\prime}-e\right)^{2}}$

$\dot{\delta}=\delta^{\prime} \cdot \omega$

$\dot{\tau}=-\dot{\alpha}_{B}=-\frac{e \cdot \dot{s}}{r_{B}^{2}}$

$\dot{\mu}=\frac{\dot{r}_{A} \cdot r_{B} \cdot \cos \mu+r_{A} \cdot \dot{r}_{B} \cdot \cos \mu-r_{A} \cdot \dot{r}_{A}-r_{B} \cdot \dot{r}_{B}}{r_{A} \cdot r_{B} \cdot \sin \mu}$

$\dot{\theta}_{A}=\dot{\phi}-\dot{\gamma}=\omega-\dot{\alpha}_{A}$

$\cos \alpha_{A}=\frac{e \cdot \sqrt{\left(s_{0}+s\right)^{2}+\left(s^{\prime}-e\right)^{2}}+r_{b} \cdot\left(s^{\prime}-e\right)}{r_{A} \cdot \sqrt{\left(s_{0}+s\right)^{2}+\left(s^{\prime}-e\right)^{2}}}$ $\sin \alpha_{A}=\frac{\left(s_{0}+s\right) \cdot\left[\sqrt{\left(s_{0}+s\right)^{2}+\left(s^{\prime}-e\right)^{2}}-r_{b}\right]}{r_{A} \cdot \sqrt{\left(s_{0}+s\right)^{2}+\left(s^{\prime}-e\right)^{2}}}$

$\cos \left(\alpha_{A}-\delta\right)=\frac{\left(s_{0}+s\right) \cdot s^{\prime}}{r_{A} \cdot \sqrt{\left(s_{0}+s\right)^{2}+\left(s^{\prime}-e\right)^{2}}}=\frac{s^{\prime}}{r_{A}} \cdot \cos \delta$

$\cos \left(\alpha_{A}-\delta\right) \cdot \cos \delta=\frac{s^{\prime}}{r_{A}} \cdot \cos ^{2} \delta$

$\cos \mu=$

$\left[\left(s_{0}+s\right)^{2}+e^{2}\right] \cdot \sqrt{\left(s_{0}+s\right)^{2}+\left(s^{\prime}-e\right)^{2}}$

$\frac{-r_{b} \cdot\left[\left(s_{0}+s\right)^{2}+e^{2}-e \cdot s^{\prime}\right]}{r_{A} \cdot r_{B} \cdot \sqrt{\left(s_{0}+s\right)^{2}+\left(s^{\prime}-e\right)^{2}}}$

$\sin \mu=\frac{r_{b} \cdot\left(s_{0}+s\right) \cdot s^{\prime}}{r_{A} \cdot r_{B} \cdot \sqrt{\left(s_{0}+s\right)^{2}+\left(s^{\prime}-e\right)^{2}}}$

\section{Determination of Dynamic Coefficient D}

The dynamic coefficient at the module B takes the form (2.46), where $\operatorname{cas}^{2} \delta$ is given by relation (2.47) and $\theta_{A}^{I}$ is obtained from expression (2.48):

$D=\theta_{A}^{I} \cdot \cos ^{2} \delta$

$\cos ^{2} \delta=\frac{\left(s_{0}+s\right)^{2}}{\left(s_{0}+s\right)^{2}+\left(s^{\prime}-e\right)^{2}}$

$\theta_{A}^{I}=\left[\left(s_{0}+s\right)^{2}+e^{2}-e \cdot s^{\prime}-r_{b} \cdot \sqrt{\left(s_{0}+s\right)^{2}+\left(s^{\prime}-e\right)^{2}}\right]$.

$\left\{\left[\left(s_{0}+s\right)^{2}+\left(s^{\prime}-e\right)^{2}\right] \cdot \sqrt{\left(s_{0}+s\right)^{2}+\left(s^{\prime}-e\right)^{2}}\right.$

$\left.+r_{b} \cdot\left[s^{\prime \prime} \cdot\left(s_{0}+s\right)-s^{\prime} \cdot\left(s^{\prime}-e\right)-\left(s_{0}+s\right)^{2}-\left(s^{\prime}-e\right)^{2}\right]\right\}$

$/\left[\left(s_{0}+s\right)^{2}+\left(s^{\prime}-e\right)^{2}\right] /\left\{\left[\left(s_{0}+s\right)^{2}+e^{2}+r_{b}^{2}\right]\right.$.

$\left.\sqrt{\left(s_{0}+s\right)^{2}+\left(s^{\prime}-e\right)^{2}}-2 \cdot r_{b} \cdot\left[\left(s_{0}+s\right)^{2}+e^{2}-e \cdot s^{\prime}\right]\right\}$

\section{Synthesis of the Distribution Mechanism Module F}

In the Fig. 16 one can see the module F, with rotation cam and rotated tappet with roll, in initial position and in some one position.

A study very precisely (exactly) is possible only when we analyze what happens in point A (the point of contact between cam and the roller of the tappet). Point $\mathrm{A}$ is defined by the vector of length (module) $\mathrm{rA}$ and $\theta_{\mathrm{A}}$ position angle, measured from the axis $\mathrm{Ox}$ and or $\alpha_{\mathrm{A}}$ angle, measured from the axis OD (Fig. 16). 
In the same mode is defined position of the point $B$ (roll center), by the vector $\bar{r}_{B}$, which is positioned in turn by the angle $\theta_{B}$ to the axis $O x$ and $\alpha_{B}$ angle to the axis $O D$ and has length $r_{B}$. Between the two presented vectors $\left(\bar{r}_{A}\right.$ and, $\left.\bar{r}_{B}\right)$ is forming an angle $\mu$. The angle $\alpha_{0}$ defines the position, basic (initial) of the vector $r_{A}$ in $\mathrm{ODB}_{0}$ right triangle, as measured from the axis $O D$. The rotation of the cam (the shaft distribution), given by the $\varphi$ angle, is measured from the axis $O x$, to the vector. As the camshaft rotates with $\varphi$ angle, the vector is rotated by the angle $\theta_{A}$ and between the two angles $\theta_{A}$ and $\varphi$ there is a mismatch (a phase shift) which is noted in Fig. 16 with $\gamma ; \gamma$ phase shift occurs and between $\alpha_{A}$ and $\alpha_{0}$ angles, which helps us to determine the exact value of its. The length (radius) of the tappet, $D B=b$, in the initial position $D B_{0}$ makes with $O D$ axis the angle $\psi_{0}$ constant, which can be determined easily together with $\alpha_{0}$ from the triangle $\mathrm{ODB}_{0}$ (with: $O D=d, D B=D B_{0}=b, O B_{0}$ $=r_{0}+r_{b}$ known; where $r_{0}$ is the radius of the basic circle on the rotary cam and $\mathrm{rb}$ is the roller radius of the follower).

From initial position until the current position, the follower rotates around the point D with a known $\psi$ angle. This $\psi$ angle, is given by the law of motion of pusher and is a function of the $\varphi$ angle. $\psi$ is known together with its derivatives: $\psi^{\prime}, \psi^{\prime \prime}, \psi^{\prime \prime}$. In general it is easier to express the movement of the follower in function of axis OD, so occurs the angle $\psi_{2}=\psi_{0}+\psi$ (with: $\psi_{2}{ }^{\prime}=\psi^{\prime}, \psi_{2}{ }^{\prime \prime}=\psi^{\prime \prime}$ ).

From ODB triangle, with known lengths $O D=d, D B$ $=b$ and $\psi_{2}$ angle, one determines the length $O B=r_{B}$, the $D O B=\alpha_{B}$ angle and the $O B D=\beta_{2}$ angle (Fig. 17). Angle $B$ sought, with angles $\beta_{2}$ and $\tau$, totals 180 [deg]; and $\tau+\delta=90$ [deg]; with delta known, results $\tau$ and the $B$ angle. Now, with $r_{B}, r_{b}$ and $B$ known (from the triangle $O B A$ ) we can determine $r_{A}$ and $\mu$.

\section{Synthesis of the Cam Profile}

Now it can make the synthesis of the cam profile with the next relationships (3.1-3.4):

$$
\begin{aligned}
& \alpha_{A}=\alpha_{B}+\mu \\
& \gamma=\alpha_{A}-\alpha_{0} \\
& \theta_{A}=\phi+\gamma \\
& \left\{\begin{array}{l}
x_{A}=r_{A} \cdot \cos \theta_{A} \\
y_{A}=r_{A} \cdot \sin \theta_{A}
\end{array}\right.
\end{aligned}
$$

To do this, it must determine first the pressure $\delta$ angle.

\section{Determination of the Pressure $\delta$ Angle}

Now one presents shortly one known method to determine the pressure angle $\delta$ at the rotary cam and rocking tappet with roll (Module F, Fig. 18).

The pressure angle is defined between two straight lines: $n-n$ and $t-t$ (the line $n-n$, pass through the points $A$ and $B$ and is perpendicular in $A$ at the two profiles in contact; the line $\mathrm{t}$-t, pass through the point $B$ and is perpendicular in $\mathrm{B}$ on the line DB which represent the tappet axis).

One builds (scale) the speed triangle rotated with 90 [deg] (Fig. 18); the cam velocity in $B\left(v B_{1}\right)$ appears along the $B O$, oriented from $B$ to $O$, the reduced velocity of the tappet in $B$ point $\left(v B_{2}\right)$ appears along the $B D$, oriented from $B$ to $b_{2}$ and the sliding between profiles velocity in the point $B\left(v B_{2} B_{1}\right)$ appears along the $n-n$ line, oriented from $O$ to $b_{2}$.

It takes the pole of the fold (rotated) speeds, $\mathrm{Pv}$, in B and the velocities scale $k_{v}=k_{l} \cdot \omega_{1} .\left((B O)=\left(P v b_{1}\right)=\right.$ $v B_{1} /\left[k_{l} \cdot \omega_{1}\right] ;\left(B b_{2}\right)=\left(P v b_{2}\right)=v B_{2} /\left[k_{l} \cdot \omega_{1}\right] ;\left(O b_{2}\right)=(\mathrm{b} 1 \mathrm{~b} 2)$ $\left.=v B_{2} B_{1} /\left[k_{l} \cdot \omega_{1}\right]\right)$. It determines the lengths with the relationships 3.5 and 3.6:

$$
\left\{\begin{array}{l}
D B=b ; B b_{2}=\frac{v_{B_{2}}}{\omega_{1}}=b \cdot \psi^{\prime} ; C D=d \cdot \cos \psi_{2} \\
O C=d \cdot \sin \psi_{2} ; b_{2} D=b-b \cdot \psi^{\prime} \\
C b_{2}=C D-b_{2} D=d \cdot \cos \psi_{2}-\left(b-b \cdot \psi^{\prime}\right) \\
=d \cdot \cos \psi_{2}+b \cdot \psi^{\prime}-b
\end{array}\right.
$$

From the $O D b_{2}$ triangle, one determines the length $\mathrm{Ob}_{2}$, (relation 3.6):

$$
\begin{aligned}
& O b_{2}=R A D= \\
& =\sqrt{d^{2}+\left(b-b \cdot \psi^{\prime}\right)^{2}-2 \cdot d \cdot\left(b-b \cdot \psi^{\prime}\right) \cdot \cos \psi_{2}}
\end{aligned}
$$

With the known lengths one can determine now the trigonometric functions of the $\delta$ pressure angle, with the relationships (3.7-3.9):

$$
\begin{aligned}
& \sin \delta=\frac{d \cdot \cos \psi_{2}+b \cdot \psi^{\prime}-b}{\sqrt{d^{2}+\left(b-b \cdot \psi^{\prime}\right)^{2}-2 \cdot d \cdot\left(b-b \cdot \psi^{\prime}\right) \cdot \cos \psi_{2}}}= \\
& =\frac{d \cdot \cos \psi_{2}+b \cdot \psi^{\prime}-b}{R A D} \\
& \cos \delta=\frac{d \cdot \sin \psi_{2}}{\sqrt{d^{2}+\left(b-b \cdot \psi^{\prime}\right)^{2}-2 \cdot d \cdot\left(b-b \cdot \psi^{\prime}\right) \cdot \cos \psi_{2}}}= \\
& =\frac{d \cdot \sin \psi_{2}}{R A D} \\
& \operatorname{tg} \delta=\frac{d \cdot \cos \psi_{2}+b \cdot \psi^{\prime}-b}{d \cdot \sin \psi_{2}}
\end{aligned}
$$




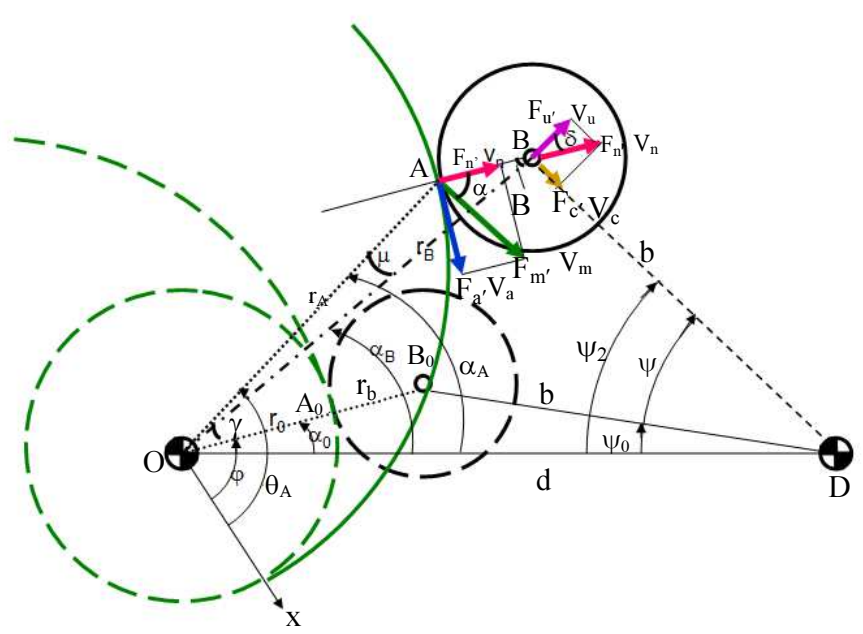

Fig. 16: Mechanism with rotating cam and rotating tappet with roll

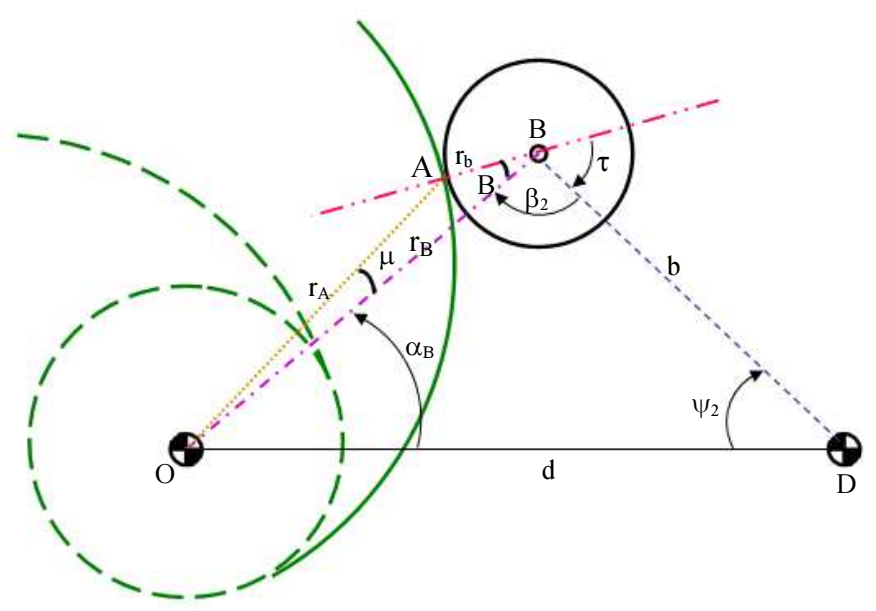

Fig. 17: Determination of angle B

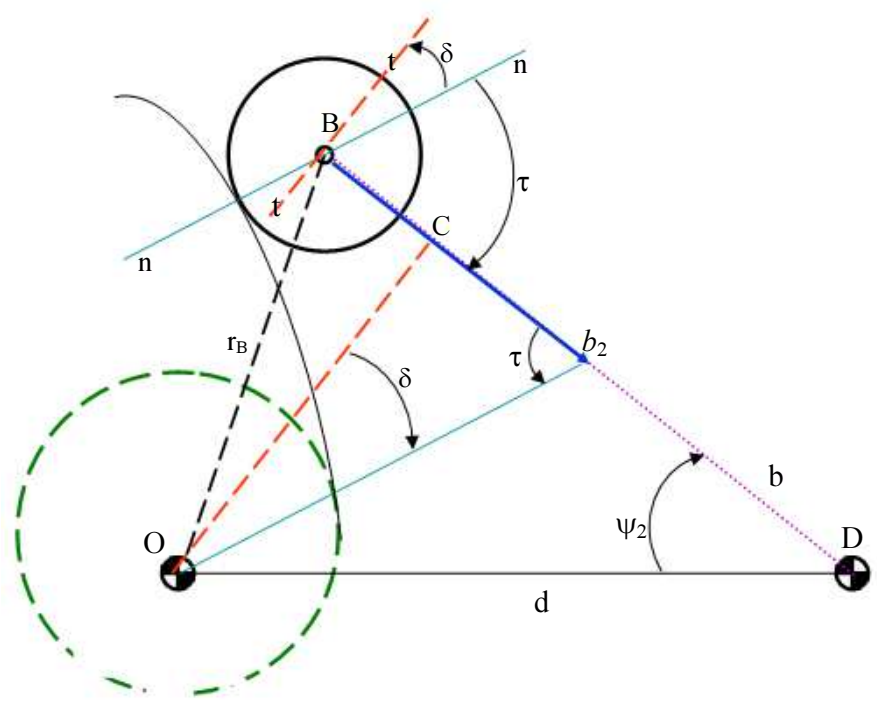

Fig. 18: Determination of the pressure angle, $\delta$ 


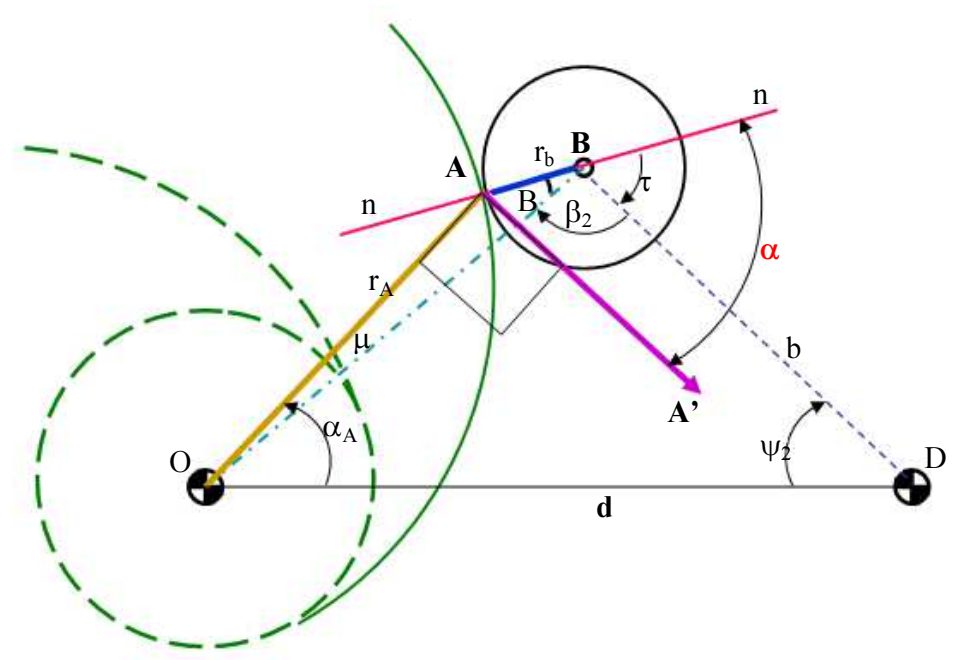

Fig. 19: Determination of the additionally pressure angle $\alpha$

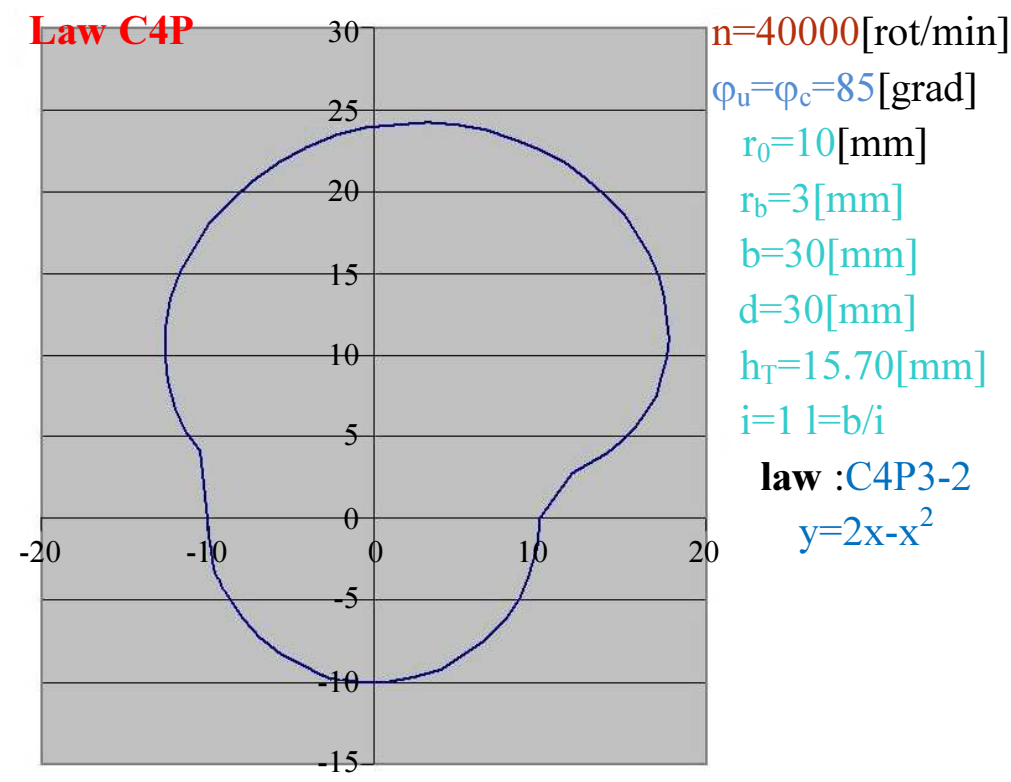

Fig. 20: Synthesis of the cam profile for module F with the law C4P

\section{Determination of the Pressure $\alpha$ Angle}

Further $\alpha$ pressure-angle is determined (where $\alpha$ is an additional pressure-angle), to the rotary cam and rotating follower with roll (Module F). This angle appears between the direction $\mathrm{n}-\mathrm{n}$ and right segment $\mathrm{AA}^{\prime}$, perpendicular in A on OA (Fig. 19).

From some triangle $\mathrm{OAB}$ was expressed and $\mathrm{OAB}$ angle (Fig. 19). From the angle OAB directly subtract $90^{\circ}$ and get extra pressure $\alpha$ angle. The calculation formulas are (3.10-3.20):

$\alpha=O A B-90$

$$
\begin{aligned}
& \sin \alpha=\sin (O A B-90)=\epsilon \\
& =-\sin (90-O A B)=-\cos (O A B) \\
& \cos \alpha=\cos (O A B-90)= \\
& =\cos (90-O A B)=\sin (O A B)=\frac{r_{B}}{r_{A}} \cdot \sin B \\
& \cos \alpha_{B}=\frac{d-b \cdot \cos \psi_{2}}{r_{B}} \\
& \sin \alpha_{B}=\frac{b \cdot \sin \psi_{2}}{r_{B}}
\end{aligned}
$$




$$
\begin{aligned}
& \sin \delta=\frac{d \cdot \cos \psi_{2}+b \cdot \psi^{\prime}-b}{R A D} \\
& \cos \delta=\frac{d \cdot \sin \psi_{2}}{R A D}
\end{aligned}
$$

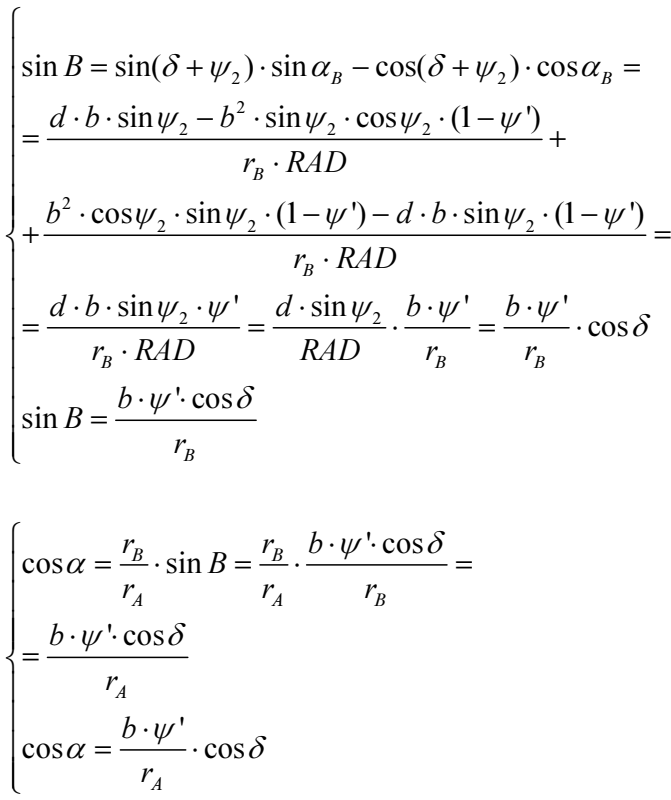

The $\cos \alpha$ can be expressed in a simplified form (see the relation 3.20 ).

\section{Basic Kinematics of Module F}

Below are presented a few parameters determining the kinematics (which constitutes the basis of this mechanism); relations: 3.21-3.56:

$$
\begin{aligned}
& \cos \psi_{0}=\frac{b^{2}+d^{2}-\left(r_{0}+r_{b}\right)^{2}}{2 \cdot b \cdot d} \\
& \psi_{2}=\psi+\psi_{0}
\end{aligned}
$$

$R A D=\sqrt{d^{2}+b^{2} \cdot\left(1-\psi^{\prime}\right)^{2}-2 \cdot b \cdot d \cdot\left(1-\psi^{\prime}\right) \cdot \cos \psi_{2}}$

$\sin \delta=\frac{d \cdot \cos \psi_{2}+b \cdot \psi^{\prime}-b}{R A D}$

$\cos \delta=\frac{d \cdot \sin \psi_{2}}{R A D}$

$\operatorname{tg} \delta=\frac{d \cdot \cos \psi_{2}+b \cdot \psi^{\prime}-b}{d \cdot \sin \psi_{2}}$

$\delta^{\prime}=\frac{b \cdot \psi^{\prime \prime}-d \cdot \sin \psi_{2} \cdot \psi^{\prime}-d \cdot \operatorname{tg} \delta \cdot \cos \psi_{2} \cdot \psi^{\prime}}{d \cdot \sin \psi_{2}} \cdot \cos ^{2} \delta$

$r_{B}^{2}=b^{2}+d^{2}-2 \cdot b \cdot d \cdot \cos \psi_{2}$

$r_{B}=\sqrt{r_{B}^{2}}$

$r_{B}^{I}=\frac{b \cdot d \cdot \sin \psi_{2} \cdot \psi^{\prime}}{r_{B}}$

$\cos \alpha_{B}=\frac{d^{2}+r_{B}^{2}-b^{2}}{2 \cdot d \cdot r_{B}}$

$\sin \alpha_{B}=\frac{b \cdot \sin \psi_{2}}{r_{B}}$

$\alpha_{B}^{I}=\frac{d^{2}-b^{2}-r_{B}^{2}}{2 \cdot r_{B}^{2}} \cdot \psi^{\prime}$

$\left\{\begin{array}{l}\sin \left(\delta+\psi_{2}\right)=\sin \delta \cdot \cos \psi_{2}+\sin \psi_{2} \cdot \cos \delta= \\ =\frac{d-b \cdot \cos \psi_{2} \cdot\left(1-\psi^{\prime}\right)}{R A D}\end{array}\right.$

$\left\{\begin{array}{l}\cos \left(\delta+\psi_{2}\right)=\cos \delta \cdot \cos \psi_{2}-\sin \delta \cdot \sin \psi_{2}= \\ =\frac{b \cdot \sin \psi_{2} \cdot\left(1-\psi^{\prime}\right)}{R A D}\end{array}\right.$

$\left\{\begin{array}{l}\cos B=\sin \left(\delta+\psi_{2}\right) \cdot \cos \alpha_{B}+ \\ +\sin \alpha_{B} \cdot \cos \left(\delta+\psi_{2}\right)= \\ =\frac{d^{2}+b^{2} \cdot\left(1-\psi^{\prime}\right)-d \cdot b \cdot \cos \psi_{2} \cdot\left(2-\psi^{\prime}\right)}{r_{B} \cdot R A D}\end{array}\right.$

$\left\{\begin{array}{l}\sin B=\sin \left(\delta+\psi_{2}\right) \cdot \sin \alpha_{B}- \\ -\cos \left(\delta+\psi_{2}\right) \cdot \cos \alpha_{B}=\frac{b \cdot \psi^{\prime}}{r_{B}} \cdot \cos \delta\end{array}\right.$ 


$$
\begin{aligned}
& r_{A}^{2}=r_{B}^{2}+r_{b}^{2}-2 \cdot r_{b} \cdot r_{B} \cdot \cos B \\
& r_{A}=\sqrt{r_{A}^{2}} \\
& \cos \mu=\frac{r_{A}^{2}+r_{B}^{2}-r_{b}^{2}}{2 \cdot r_{A} \cdot r_{B}} \\
& \sin \mu=\frac{r_{b}}{r_{A}} \cdot \sin B \\
& B^{\prime}=\delta^{\prime}+\psi^{\prime}+\alpha_{B}^{\prime} \\
& \theta_{A}^{\prime}=1+\alpha_{A}^{\prime} \\
& r_{A}^{\prime}=\frac{r_{B} \cdot r_{B}^{\prime}-r_{b} \cdot r_{B}^{\prime} \cdot \cos B+r_{b} \cdot r_{B} \cdot \sin B \cdot B^{\prime}}{r_{A}} \\
& \cos \alpha \cdot \cos \delta=\frac{\psi^{\prime} \cdot b}{r_{A}} \cdot \cos { }^{2} \delta \\
& \mu^{\prime}=\frac{r_{b}}{r_{A} \cdot \cos \mu} \cdot\left(\cos B \cdot B^{\prime}-\sin B \cdot \frac{r_{A}^{\prime}}{r_{A}}\right) \\
& \alpha_{A}=\alpha_{B}+\mu \\
& \alpha_{A}^{\prime}=\alpha_{B}^{\prime}+\mu^{\prime} \\
& \cos \alpha_{A}=\cos \alpha_{B} \cos \mu-\sin \alpha_{B} \sin \mu \\
& \sin \alpha_{A}=\sin \alpha_{B} \cos \mu+\cos \alpha_{B} \sin \mu \\
& r_{A}+\alpha_{A}-\psi_{2}-\delta \\
& \gamma_{A} \cdot \sin \alpha_{A}-\cos \left(\psi_{2}+\delta\right) \cdot \cos \alpha_{A}
\end{aligned}
$$

Relations to Draw (Synthesis) the Cam Profile, to the Module F

Next few cinematic parameters are determined by which cam profile can be traced directly (to the rotating cam and rocker follower with roll); relations 3.57-3.64:

$$
\cos \alpha_{0}=\frac{\left(r_{0}+r_{b}\right)^{2}+d^{2}-b^{2}}{2 \cdot\left(r_{0}+r_{b}\right) \cdot d}
$$

$$
\begin{aligned}
& \sin \alpha_{0}=\frac{b \cdot \sin \psi_{0}}{r_{0}+r_{b}} \\
& \cos \gamma=\cos \alpha_{A} \cdot \cos \alpha_{0}+\sin \alpha_{A} \cdot \sin \alpha_{0} \\
& \sin \gamma=\sin \alpha_{A} \cdot \cos \alpha_{0}-\sin \alpha_{0} \cdot \cos \alpha_{A} \\
& \cos \theta_{A}=\cos \phi \cdot \cos \gamma-\sin \phi \cdot \sin \gamma \\
& \sin \theta_{A}=\sin \phi \cdot \cos \gamma+\sin \gamma \cdot \cos \phi \\
& x_{A}=r_{A} \cdot \cos \theta_{A} \\
& y_{A}=r_{A} \cdot \sin \theta_{A}
\end{aligned}
$$

\section{The Cam Profile Module F of Law C4P}

In the Fig. 20 one can see the cam profile for an original law called by author C4P, which support a rotation speed of the drive shaft of 40000 [rpm], compared with the classical distribution who support a maximum drive shaft rotation speed of 5000-6000 [rpm].

\section{The Dynamic Coefficient D}

The dynamic coefficient is expressed with relation (3.65), where has the expression (3.66) and is given by the expression (3.67):

$D=\theta_{A}^{\prime} \cdot \cos ^{2} \delta$

$\cos ^{2} \delta=$

$=\frac{d^{2} \cdot \sin ^{2} \psi_{2}}{d^{2}+b^{2} \cdot\left(1-\psi^{\prime}\right)^{2}-2 \cdot b \cdot d \cdot\left(1-\psi^{\prime}\right) \cdot \cos \psi_{2}}$

$\theta_{A}^{\prime}=1+\frac{d^{2}-b^{2}-r_{B}^{2}}{2 \cdot r_{B}^{2}} \cdot \psi^{\prime}+$

$+\frac{r_{b}}{r_{A} \cdot \cos \mu} \cdot\left(\cos B \cdot B^{\prime}-\sin B \cdot \frac{r_{A}^{\prime}}{r_{A}}\right)$

\section{Synthesis of the Distribution Mechanism Module H}

In the Fig. 21 one can see the module $\mathrm{H}$, with rotation cam and rotated plane tappet, in initial position and in some one position.

For general use kinematic relations are inserted 4.1-4.4:

$$
\begin{aligned}
& A H= \\
& =\left[\sqrt{d^{2}-\left(r_{0}-b\right)^{2}} \cdot \cos \psi-\left(r_{0}-b\right) \cdot \sin \psi\right] \cdot \frac{\psi^{\prime}}{1-\psi^{\prime}}
\end{aligned}
$$


$O H=b+\left(r_{0}-b\right) \cdot \cos \psi+\sqrt{d^{2}-\left(r_{0}-b\right)^{2}} \cdot \sin \psi$

$r^{2}=A H^{2}+O H^{2}$

$\left\{\begin{array}{l}\sin \tau=\frac{A H}{r} ; \\ \sin ^{2} \tau=\frac{A H^{2}}{r^{2}}=\frac{A H^{2}}{A H^{2}+O H^{2}}\end{array}\right.$
In the Fig. 22 one can see and the velocities and the forces of this type of distribution mechanism.

In the Fig. 23 it can see a cam profile at the module $\mathrm{H}$ (with rotation cam and rotating plate follower), for a law sine.

The phase angle is $\varphi_{\mathrm{u}}=\varphi_{\mathrm{c}}=80[\mathrm{deg}]$; core radius has value $\mathrm{r}_{0}=13[\mathrm{~mm}]$.

In the Fig. 24 it can see a cam profile at the module $\mathrm{H}$ (with rotation cam and rotating plate follower), for a law $\mathrm{C} 4 \mathrm{P}$. The phase angle is $\varphi_{\mathrm{u}}=\varphi_{\mathrm{c}}=70$ [deg]; core radius has value $\mathrm{r}_{0}=20[\mathrm{~mm}]$. This profile support a drive shaft rotation speed of 30000 [rpm].

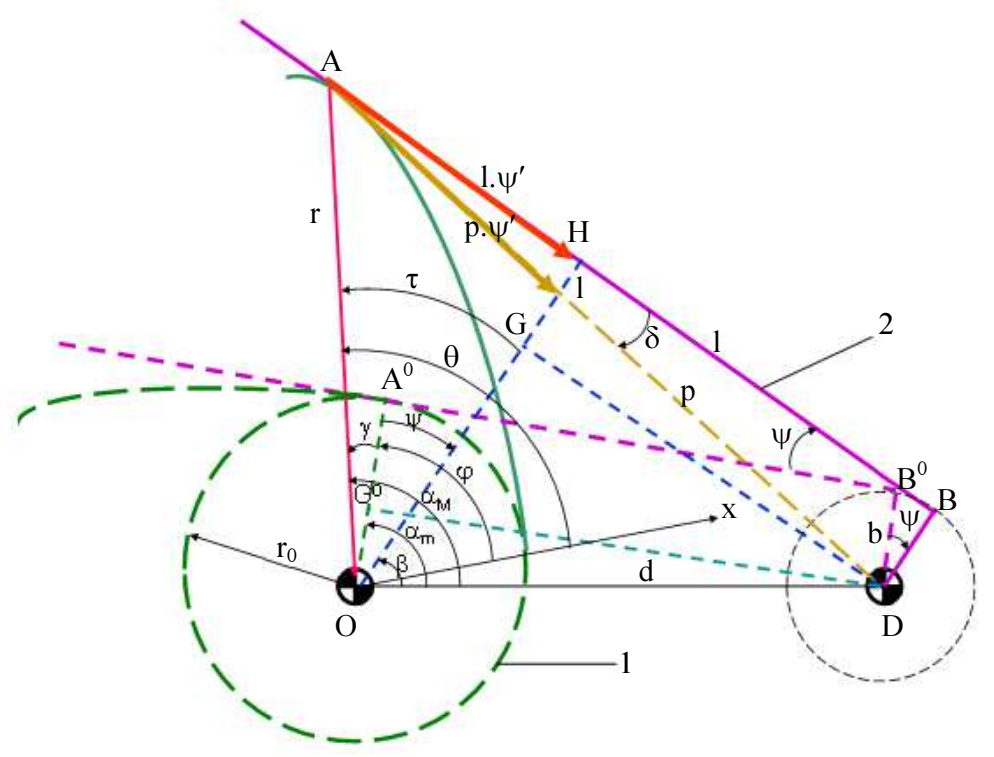

Fig. 21: The distribution mechanism for module $H$

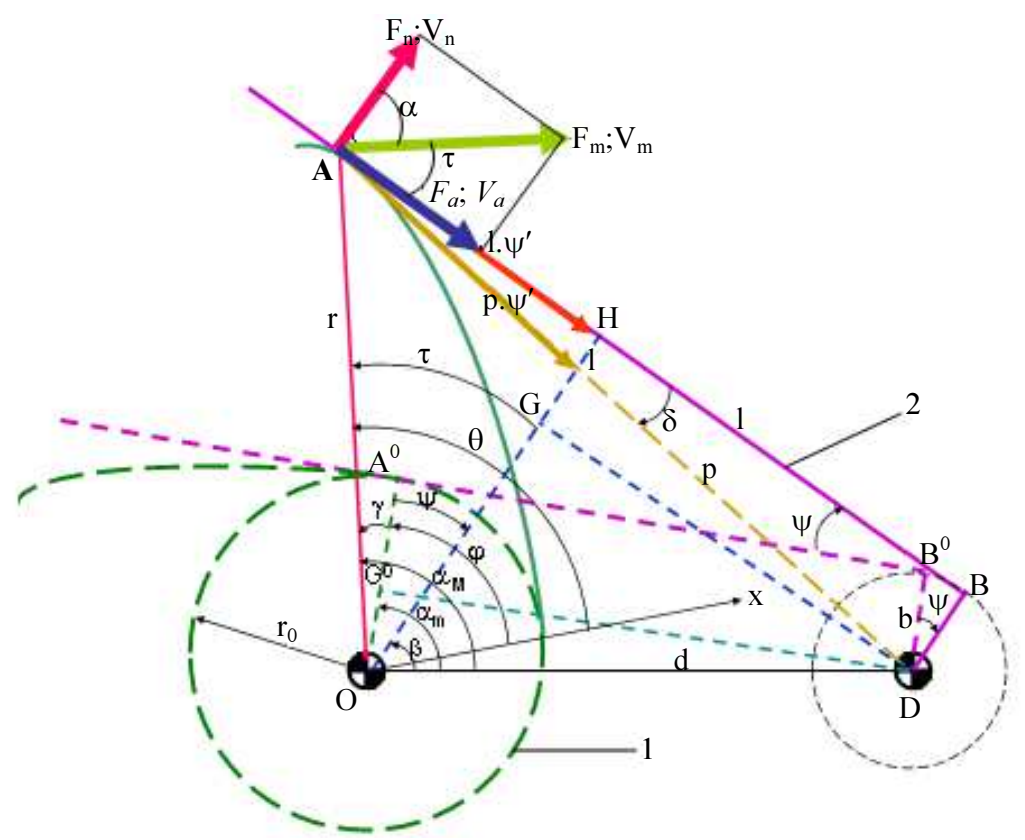

Fig. 22: The distribution mechanism module H; forces and velocities 


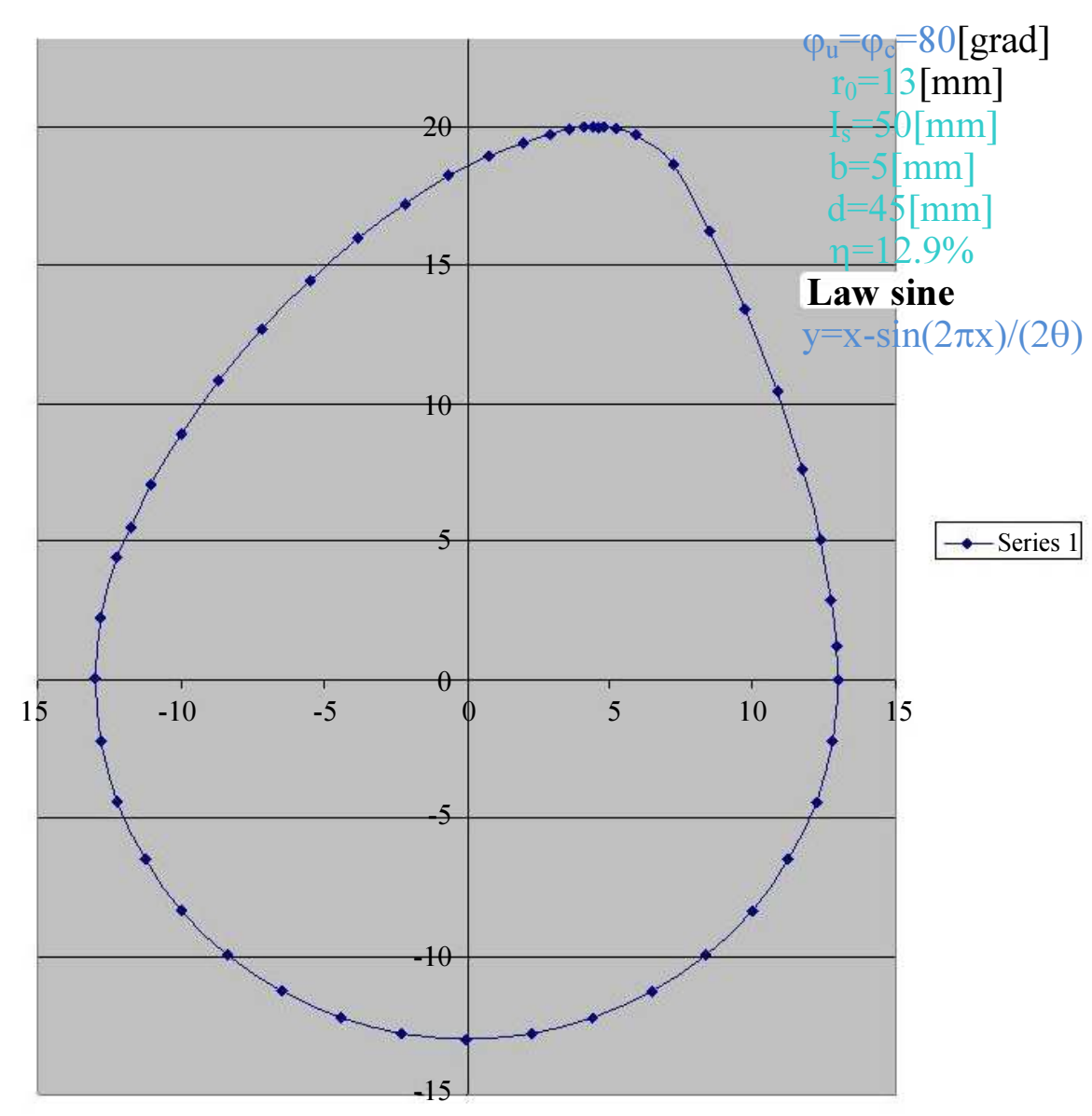

Fig. 23: A cam profile at the module $H$, for a law sine: $\varphi u=\varphi c=80[\mathrm{deg}] ; \mathrm{r} 0=13[\mathrm{~mm}] ; \eta=12.9 \%$

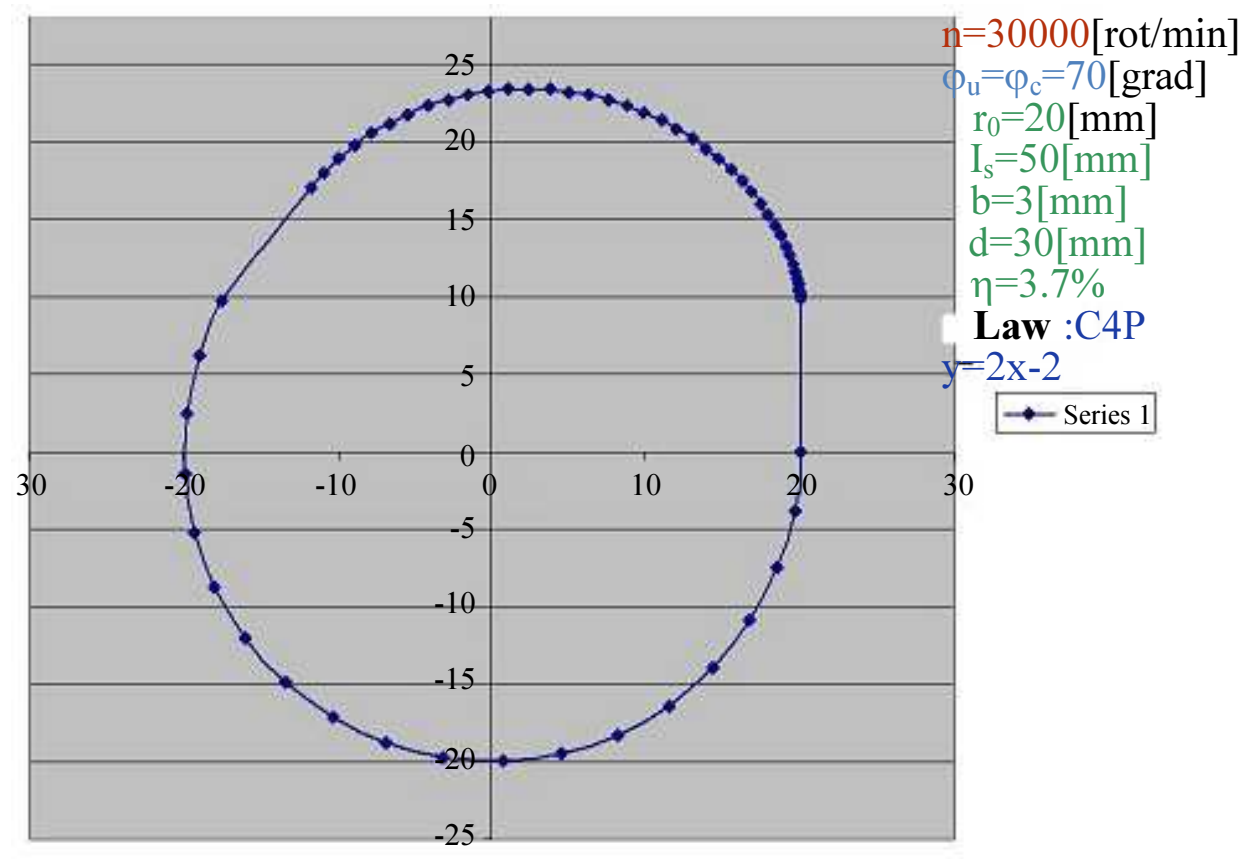

Fig. 24: A cam profile at the module H, for a law C4P: $\varphi u=\varphi c=70[\mathrm{deg}] ; \mathrm{r} 0=20[\mathrm{~mm}] ; \eta=4 \%$ 


\section{Discussion}

Rigid memory mechanisms, commonly known as cam and follower mechanisms, have revolutionized the world several times. The first time they have radically changed the face of the world when they were massively introduced to automatic tissue machinery, in the Netherlands in the 18th century and then immediately developed in England and then all over the world. Tissue wars as these machines were called at that time managed to mark a turning point for humanity in its development, as they quickly changed the way of production from weaving women to automated tissue machines, following a scientific-technical revolution, social ...

The first valve mechanisms appeared in 1844, being used in steam locomotives; they were designed and built by the Belgian mechanical engineer Egide Walschaerts.

The first cam mechanisms are used in England and the Netherlands in the tissue wars.

In 1719, in England, some John Kay opens in a fivestory building a spinning facto plant. With a staff of over 300 women and children, this would be the world's first factory. He also becomes famous by inventing the flying sail, which makes the tissue faster. But the machines were still manually operated. It was not until 1750 that the textile industry was to be revolutionized by the widespread application of this invention. Initially, the weavers opposed it, destroying flying sails and banishing the inventor. By 1760 the wars and the first factories appeared in the modern sense of the word. It took the first engines. For over a century, the Italian Giovanni Branca had proposed the use of steam to drive turbines. Subsequent experiments were not satisfying. In France and England, brand inventors, like Denis Papin or the Worcester Marquis, came up with new ideas. At the end of the seventeenth century, Thomas Savery had already built the "friend of the miner", a steam engine that put into operation a pump to remove water from the galleries. Thomas Newcomen has made the commercial version of the steam pump and engineer James Watt develops and adapts a speed regulator that improves the engine's net. Together with Mathiew Boulton, he builds the first steam-powered engines and in less than half a century, the wind that fed for more than 3,000 years, the propulsion power at sea now only inflates pleasure boats. In 1785 came into operation, the first steam-powered steamer followed quickly by a few dozen.

The first distribution mechanisms occur with fourstroke engines for cars.

In 1680, Dutch physicist Christian Huygens designs the first internal combustion engine.

In 1807, Swiss François Isaac de Rivaz invented an internal combustion engine that uses a liquid mixture of hydrogen and oxygen as fuel. However, Rivaz's engine for its new engine has been a major failure, so its engine has gone dead, with no immediate application.
In 1824, English engineer Samuel Brown adapted a steam engine to make it work with gasoline.

In 1858, Belgian engineer Jean Joseph Etienne Lenoir invented and patented two years later, practically the first real-life internal combustion engine with spark-ignition, liquid gas (extracted from coal), a two-stroke engine . In 1863 , the Belgian Lenoir is the one who adapts to his engine a carburetor, making it work with oil (or gasoline).

In 1862, the French engineer Alphonse Beau de Rochas first patented the four-stroke internal combustion engine (but without building it).

It is the merit of the German engineers Eugen Langen and Nikolaus August Otto to build (physically, practically the theoretical model of the French Rochas), the first four-stroke internal combustion engine in 1866, with electric ignition, charging and distribution in a form Advanced.

Ten years later (in 1876), Nikolaus August Otto patented his engine.

In the same year (1876), Sir Dougald Clerk, he puts the two-stroke engine of Belgian Lenoir (bringing it to the shape known today).

In 1885, Gottlieb Daimler arranges a four-stroke internal combustion engine with a single vertical cylinder and an improved carburetor.

A year later his compatriot Karl Benz brings some improvements to the four-stroke engine. Both Daimler and Benz were working new engines for their new cars (so famous).

In 1889, Daimler improves the four-stroke internal combustion engine, building a "two cylinder in V" and bringing the distribution to today's classic form, "with mushroom-shaped valves."

In 1890, Wilhelm Maybach built the first fourcylinder four-cylinder internal combustion.

In 1892, German engineer Rudolf Christian Karl Diesel invented the compression-ignition engine, in short the diesel engine.

Today, the models of distribution mechanisms have greatly diversified, being vital to internal combustion engines mounted on cars, which today are produced annually in over 60-70 million extra copies and the car fleet is more than a billion after 2010 years.

Essential changes to this mechanism have been attempted by replacing it with induction coils that move a linear spike, but the forces and high moments in the system have caused these electromagnetic mechanisms to break rapidly after a small number of cycles, not having the resistance of the classic distribution mechanism created in 1866 by Otto.

The synthesis of these types of distribution mechanisms can be done shortly by Cartesian coordinates, but for the determination of these coordinates, we also need trigonometric parameters. 
This synthesis method, which is based on trigonometric parameters (in a large proportion), can be called a trigonometric synthesis method. With the internal combustion engine, there is a great loss of power through the distribution mechanism, which is why we must try to improve the functionality of this mechanism.

Based on the relationships presented, it is still possible to determine both the analysis and the synthesis of the dynamic mechanism.

The short relationships presented in this study are therefore of essential nature, as they can then generate dynamic relationships.

As long as we produce electricity and heat by burning fossil fuels, it is useless to try to replace all electric motors as electricity and the pollution will be even greater.

However, it is good to continually improve thermal motors to reduce fuel consumption.

With the internal combustion engine, there is a great loss of power through the distribution mechanism, which is why we must try to improve the functionality of this mechanism.

The modular combustion chamber has a unique design of the valve actuator. The valve springs exert great forces to ensure their rapid closure. The forces for their opening are provided by camshaft driven camshafts.

Economy: Velcro and cams are large, ensuring smooth and precise action on the valves. This is reflected in low fuel consumption.

Reduced pollutant emissions: The accuracy of the distribution mechanism is a vital factor in engine efficiency and clean combustion.

Cost of operation: An important benefit brought by the size of the tachets is their low wear rate. This reduces the need for adjustments. Valve operation remains constant over a long period of time. If adjustments are required, they can be made quickly and easily.

Today, more than ever, we want to eliminate internal combustion engines or even thermal ones that have been carrying us for over 200 years and replacing them with other more modern engines.

Water engines have the best note on this, but research in the field is not much desired by some of the planet's leaders, these projects not being sponsored enough and fair. A water engine actually burns hydrogen out of the water by modern methods, with no much-extracting energy, which makes water an ideal energy storage facility. By combustion, water is naturally reclaimed, the burning of hydrogen is complete and free of noxious, unlike fossil fuels, petroleum and gaseous fuels.

When burning hydrogen, it is always preferable to have a thermal cell burner instead of a classic engine because hydrogen burns ten times faster than conventional fuels and also presents the risk of explosion.

For this reason, the burning of stored hydrogen or the extracted directly from the water will always be done in special burners, which produce heat transformed by chemical processes into electrical energy that loads some modern accumulators so that the solution is automatically conducive to the final use of some motors electric on the vehicle in question, so the thermal engine disappears from the equation when talking about hydrogen fuel or water.

And from the nostalgia for keeping the thermal engines, but especially from the desire of oil and gas magnates to preserve their priorities on the extracted gas and their oil, it is still undesirable to move on to such a modern solution, with water.

The problem what will happen with a park of motorized cars on classic fuels, a park of over one billion cars, is not as hard as it may seem, because no ordinary man will buy such classic cars anymore, if will occur cars with water, cheap and with great capabilities.

We notice that higher amounts are paid for research on permanent magnetic motors, which for more than 20 years since they appeared did not evolve too much due to the rapid demagnetization of the materials used.

It seems to be preferable for scientific research to focus on the slippery ground from the very beginning, just as oil and gas will still be the most desirable for motorists in this mode.

The simple electric engine develops slowly with the fuel cell models.

Its problems are still high because electric cars are still expensive, heavy to load and can not be loaded in every place and the loading time is still high, but especially the autonomy of such cars is still small compared to the classical ones with fossil fuels.

Nowadays, new oil resources and new gas reserves have also emerged, considering the shale gases (of depth that can be extracted today), so that the planet's gas reserves have increased from 40-50 years to about 2000 years.

The burning of hydrogen is clean, that of gas burning is quite complete and yet it is keeping the very polluting gasoline and diesel.

As very large gas reserves have been discovered, they are now being transformed into pollutants, gasoline and diesel, in very large processing plants (three are already working at high capacity), although they will then be required by limitation rules polluting by the production of sophisticated devices (Euro 6) that produce large losses and anyway the pollution remains. It would be easier to switch to gas burning than to convert gas into gasoline and diesel and then introduce a Euro 7 to filter and limit the pollution caused by gasoline and diesel. Current world policies are completely contradictory, convert non-polluting gas into diesel and then impose anti-pollution rules on diesel fuel.

Under these circumstances, it is still necessary to further study and improve the distribution systems of thermal engines to limit the levels of pollutant emissions in this way. 


\section{Conclusion}

The synthesis of these types of distribution mechanisms can be done shortly by Cartesian coordinates, but for the determination of these coordinates, we also need trigonometric parameters.

This synthesis method, which is based on trigonometric parameters (in a large proportion), can be called a trigonometric synthesis method. With the internal combustion engine, there is a great loss of power through the distribution mechanism, which is why we must try to improve the functionality of this mechanism.

Based on the relationships presented, it is still possible to determine both the analysis and the synthesis of the dynamic mechanism.

The short relationships presented in this study are therefore of essential nature, as they can then generate dynamic relationships.

As long as we produce electricity and heat by burning fossil fuels, it is useless to try to replace all electric motors as electricity and the pollution will be even greater.

However, it is good to continually improve thermal motors to reduce fuel consumption.

With the internal combustion engine, there is a great loss of power through the distribution mechanism, which is why we must try to improve the functionality of this mechanism. Under these circumstances, it is still necessary to further study and improve the distribution systems of thermal engines to limit the levels of pollutant emissions in this way.

In addition, these mechanisms are also used for mechanical transmissions everywhere, for automated machines, for robotics and mechatronization, as well as for medical devices.

\section{Acknowledgement}

This text was acknowledged and appreciated by Dr. Veturia CHIROIU Honorific member of Technical Sciences Academy of Romania (ASTR) PhD supervisor in Mechanical Engineering.

\section{Funding Information}

Research contract: 1-Research contract: Contract number 36-5-4D/1986 from 24IV1985, beneficiary CNST RO (Romanian National Center for Science and Technology) Improving dynamic mechanisms.

2-Contract research integration. 19-91-3 from 29.03.1991; Beneficiary: MIS; TOPIC: Research on designing mechanisms with bars, cams and gears, with application in industrial robots.

3-Contract research. GR 69/10.05.2007: NURC in 2762; theme 8: Dynamic analysis of mechanisms and manipulators with bars and gears.

4-Labor contract, no. 35/22.01.2013, the UPB, "Stand for reading performance parameters of kinematics and dynamic mechanisms, using inductive and incremental encoders, to a Mitsubishi Mechatronic System" "PN-IIIN-CI-2012-1-0389".

All these matters are copyrighted! Copyrights: 394qodGnhhtej, from 17-02-2010 13:42:18; 463vpstuCGsiy, from 20-03-2010 12:45:30; 631sqfsgqvutm, from 24-05-2010 16:15:22; 933CrDztEfqow, from 07-01-2011 13:37:52.

\section{Ethics}

This article is original and contains unpublished material. Authors declare that are not ethical issues and no conflict of interest that may arise after the publication of this manuscript.

\section{References}

Ab-Rahman, M.S., H. Guna, MH. Harun, SD. Zan and K. Jumari, 2009. Cost-effective fabrication of self-made $1 \times 12$ polymer optical fiber-based optical splitters for automotive application. Am. J. Eng. Applied Sci., 2: 252-259. DOI: 10.3844/ajeassp.2009.252.259

Abam, F.I., I.U. Ugot and D.I. Igbong, 2012. Performance analysis and components irreversibilities of a (25 MW) gas turbine power plant modeled with a spray cooler. Am. J. Eng. Applied Sci., 5: 35-41.

DOI: 10.3844/ajeassp.2012.35.41

Abdelkrim, H., S.B. Othman, A.K.B. Salem and S.B. Saoud, 2012. Dynamic partial reconfiguration contribution on system on programmable chip architecture for motor drive implementation. Am. J. Eng. Applied Sci., 5: 15-24.

DOI: 10.3844/ajeassp.2012.15.24

Abdullah, M.Z., A. Saat and Z. Hamzah, 2011. Optimization of energy dispersive x-ray fluorescence spectrometer to analyze heavy metals in moss samples. Am. J. Eng. Applied Sci., 4: 355-362. DOI: 10.3844/ajeassp.2011.355.362

Abdullah, M., A. F.M. Zain, Y. H. Ho and S. Abdullah, 2009. TEC and scintillation study of equatorial ionosphere: A month campaign over sipitang and parit raja stations, Malaysia. Am. J. Eng. Applied Sci., 2: 44-49. DOI: 10.3844/ajeassp.2009.44.49

Abdullah, H. and S.A. Halim, 2009. Electrical and magnetoresistive studies Nd doped on La-Ba-MnO3 manganites for low-field sensor application. Am. J. Eng. Applied Sci., 2: 297-303. DOI: 10.3844/ajeassp.2009.297.303

Abouobaida, H., 2016. Robust and efficient controller to design a standalone source supplied DC and AC load powered by photovoltaic generator. Am. J. Eng. Applied Sci., 9: 894-901. DOI: 10.3844/ajeassp.2016.894.901 
Abu-Ein, S., 2009. Numerical and analytical study of exhaust gases flow in porous media with applications to diesel particulate filters. Am. J. Eng. Applied Sci., 2: 70-75. DOI: 10.3844/ajeassp.2009.70.75

Abu-Lebdeh, M., G. Pérez-de León, S.A. Hamoush, R.D. Seals and V.E. Lamberti, 2016. Gas atomization of molten metal: Part II. Applications. Am. J. Eng. Applied Sci., 9: 334-349.

DOI: 10.3844/ajeassp.2016.334.349

Agarwala, S., 2016. A perspective on 3D bioprinting technology: Present and future. Am. J. Eng. Applied Sci., 9: 985-990. DOI: 10.3844/ajeassp.2016.985.990

Ahmed, M., R. Khan, M. Billah and S. Farhana, 2010. A novel navigation algorithm for hexagonal hexapod robot. Am. J. Eng. Applied Sci., 3: 320-327.

DOI: 10.3844 /ajeassp.2010.320.327

Ahmed, M.K., H. Haque and H. Rahman, 2016. An approach to develop a dynamic job shop scheduling by fuzzy rule-based system and comparative study with the traditional priority rules. Am. J. Eng. Applied Sci., 9: 202-212. DOI: 10.3844/ajeassp.2016.202.212

Akhesmeh, S., N. Pourmahmoud and H. Sedgi, 2008. Numerical study of the temperature separation in the ranque-hilsch vortex tube. Am. J. Eng. Applied Sci., 1: 181-187. DOI: 10.3844/ajeassp.2008.181.187

Akubue, A., 2011. Appropriate technology for socioeconomic development in third world countries. J. Technol. Stud., 26: 33-43.

DOI: $10.21061 /$ jots.v26il.a.6

Al-Abbas, I.K., 2009. Reduced order models of a current source inverter induction motor drive. Am. J. Eng. Applied Sci., 2: 39-43. DOI: 10.3844 /ajeassp.2009.39.43

Al-Hasan and A.S. Al-Ghamdi, 2016. Energy balance for a diesel engine operates on a pure biodiesel, diesel fuel and biodiesel-diesel blends. Am. J. Eng. Applied Sci., 9: 458-465.

DOI: 10.3844/ajeassp.2016.458.465

Al Smadi, T.A., 2011. Low cost smart sensor design. Am. J. Eng. Applied Sci., 4: 162-168. DOI: 10.3844/ajeassp.2011.162.168

Al Qadi, A.N.S., M.B.A. ALhasanat, A. AL Dahamsheh and S. AL Zaiydneen, 2016a. Using of box-benken method to predict the compressive strength of selfcompacting concrete containing Wadi Musa bentonite, Jordan. Am. J. Eng. Applied Sci., 9: 406-411. DOI: 10.3844/ajeassp.2016.406.411

Al Qadi, A.N.S., M.B.A. Alhasanat and M. Haddad, 2016b. Effect of crumb rubber as coarse and fine aggregates on the properties of asphalt concrete. Am. J. Eng. Applied Sci., 9: 558-564. DOI: 10.3844/ajeassp.2016.558.564

Aleksic, S. and A. Lovric, 2011. Energy consumption and environmental implications of wired access networks. Am. J. Eng. Applied Sci., 4: 531-539. DOI: 10.3844/ajeassp.2011.531.539
Alhasanat, M.B., A.N. Al Qadi, O.A. Al Khashman and A. Dahamsheh, 2016. Scanning electron microscopic evaluation of self-compacting concrete spalling at elevated temperatures. Am. J. Eng. Applied Sci., 9: 119-127. DOI: 10.3844/ajeassp.2016.119.127

Ali, K.S. and JL. Shumaker, 2013. Hardware in the loop simulator for multi-agent unmanned aerial vehicles environment. Am. J. Eng. Applied Sci., 6: 172-177. DOI: 10.3844 /ajeassp.2013.172.177

Ali, G.A.M., O. Fouad and S.A. Makhlouf, 2016. Electrical properties of cobalt oxide/silica nanocomposites obtained by sol-gel technique. Am. J. Eng. Applied Sci., 9: 12-16. DOI: 10.3844/ajeassp.2016.12.16

Al-Nasra, M. Daoudb and T.M. Abu-Lebdeh, 2015. The use of the super absorbent polymer as water blocker in concrete structures. Am. J. Eng. Applied Sci., 8: 659-665. DOI: 10.3844/ajeassp.2015.659.665

Alwetaishi, M.S., 2016. Impact of building function on thermal comfort: A review paper. Am. J. Eng. Applied Sci., 9: 928-945.

DOI: 10.3844/ajeassp.2016.928.945

Aly, W.M. and M.S. Abuelnasr, 2010. Electronic design automation using object oriented electronics. Am. J. Eng. Applied Sci., 3: 121-127. DOI: 10.3844 ajeassp.2010.121.127

Amani, N., 2016. Design and implementation of optimum management system using cost evaluation and financial analysis for prevention of building failure. Am. J. Eng. Applied Sci., 9: 281-296. DOI: 10.3844/ajeassp.2016.281.296

Amer, S., S. Hamoush and T.M. Abu-Lebdeh, 2015. Experimental evaluation of the raking energy in damping system of steel stud partition walls. Am. J. Eng. Applied Sci., 8: 666-677. DOI: 10.3844/ajeassp.2015.666.677

Anizan, S., K. Yusri, C.S. Leong, N. Amin and S. Zaidi et al., 2011. Effects of the contact resistivity variations of the screen-printed silicon solar cell. Am. J. Eng. Applied Sci., 4: 328-331. DOI: 10.3844 /ajeassp.2011.328.331

Angeles, J. and C. Lopez-Cajun, 1988. Optimal synthesis of cam mechanisms with oscillating flat-face followers. Mechanism Mach. Theory, 23: 1-6. DOI: 10.1016/0094-114X(88)90002-X

Antonescu, P., 2000. Mechanisms and Handlers. 1st Edn., Printech Publishing House, Bucharest.

Antonescu, P. and FIT. Petrescu, 1985. An analytical method of synthesis of cam mechanism and flat stick. Proceedings of the 4th International Symposium on Theory and Practice of Mechanisms, (TPM' 85), Bucharest.

Antonescu, P. and F.I.T. Petrescu, 1989. Contributions to cinetoelastodynamic analysis of distribution mechanisms. Bucharest. 
Antonescu, P., M. Oprean and F.I.T. Petrescu, 1985a. Contributions to the synthesis of oscillating cam mechanism and oscillating flat stick. Proceedings of the 4th International Symposium on Theory and Practice of Mechanisms, (TPM' 85), Bucharest.

Antonescu, P., M. Oprean and F.I.T. Petrescu, 1985b. At the projection of the oscillate cams, there are mechanisms and distribution variables. Proceedings of the 5th Conference of Engines, Automobiles, Tractors and Agricultural Machines, (AMA' 58), IMotors and Cars, Brasov.

Antonescu, P., M. Oprean and F.I.T. Petrescu, 1986. Projection of the profile of the rotating camshaft acting on the oscillating plate with disengagement. Proceedings of the 3rd National Computer-aided Design Symposium in the field of Mechanisms and Machine Parts, (MMP' 86), Brasov.

Antonescu, P., M. Oprean and F.I.T. Petrescu, 1987. Dynamic analysis of the cam distribution mechanisms. Proceedings of the 7th National Symposium on Industrial Robots and Space Mechanisms, (RSM' 87), Bucharest.

Antonescu, P., M. Oprean and F.I.T. Petrescu, 1988. Analytical synthesis of Kurz profile, rotating the flat cam. Mach, Build. Rev.

Antonescu, P., F.I.T. Petrescu and O. Antonescu, 1994. Contributions to the synthesis of the rotating cam mechanism and the tip of the balancing tip. Brasov.

Antonescu, P., F.I.T. Petrescu and D. Antonescu, 1997. Geometrical synthesis of the rotary cam and balance tappet mechanism. Bucharest, 3: 23-23.

Antonescu, P., F.I.T. Petrescu and O. Antonescu, 2000a. Contributions to the synthesis of the rotary disc-cam profile. Proceedings of the 8th International Conference on the Theory of Machines and Mechanisms, (TMM' 00), Liberec, Czech Republic, pp: 51-56.

Antonescu, P., F.I.T. Petrescu and O. Antonescu, 2000b. Synthesis of the rotary cam profile with balance follower. Proceedings of the 8th Symposium on Mechanisms and Mechanical Transmissions, (MMT'00), Timişoara, pp: 39-44.

Antonescu, P., F. Petrescu and O. Antonescu, 2001. Contributions to the synthesis of mechanisms with rotary disc-cam. Proceedings of the 8th IFToMM International Symposium on Theory of Machines and Mechanisms, (TMM' 01), Bucharest, ROMANIA, pp: 31-36.

Ascione, F., N. Bianco, R.F. De Masi, F. de Rossi and C. De Stasio et al., 2016. Energy audit of health care facilities: dynamic simulation of energy performances and energy-oriented refurbishment of system and equipment for microclimatic control. Am. J. Eng. Applied Sci., 9: 814-834.

DOI: 10.3844/ajeassp.2016.814.834
Augustine, A., R.D. Prakash, R. Xavier and M.C. Parassery, 2016. Review of signal processing techniques for detection of power quality events. Am. J. Eng. Applied Sci., 9: 364-370.

DOI: 10.3844 /ajeassp.2016.364.370

Aversa, R., R.V.V. Petrescu, A. Apicella and F.I.T. Petrescu, 2017a. Nano-diamond hybrid materials for structural biomedical application. Am. J. Biochem. Biotechnol., 13: 34-41.

DOI: 10.3844/ajbbsp.2017.34.41

Aversa, R., R.V. Petrescu, B. Akash, R.B. Bucinell and J.M. Corchado et al., 2017b. Kinematics and forces to a new model forging manipulator. Am. J. Applied Sci., 14: 60-80. DOI: 10.3844/ajassp.2017.60.80

Aversa, R., R.V. Petrescu, A. Apicella, F.I.T. Petrescu and J.K. Calautit et al., 2017c. Something about the $\mathrm{V}$ engines design. Am. J. Applied Sci., 14: 34-52. DOI: 10.3844/ajassp.2017.34.52

Aversa, R., D. Parcesepe, R.V.V. Petrescu, F. Berto and G. Chen et al., 2017d. Process ability of bulk metallic glasses. Am. J. Applied Sci., 14: 294-301. DOI: 10.3844/ajassp.2017.294.301

Aversa, R., R.V.V. Petrescu, B. Akash, R.B. Bucinell and J.M. Corchado et al., 2017e. Something about the balancing of thermal motors. Am. J. Eng. Applied Sci., 10: 200.217. DOI: 10.3844/ajeassp.2017.200.217

Aversa, R., F.I.T. Petrescu, R.V. Petrescu and A. Apicella, 2016a. Biomimetic FEA bone modeling for customized hybrid biological prostheses development. Am. J. Applied Sci., 13: 1060-1067. DOI: 10.3844/ajassp.2016.1060.1067

Aversa, R., D. Parcesepe, R.V. Petrescu, G. Chen and F.I.T. Petrescu et al., 2016b. Glassy amorphous metal injection molded induced morphological defects. Am. J. Applied Sci., 13: 1476-1482. DOI: 10.3844/ajassp.2016.1476.1482

Aversa, R., R.V. Petrescu, F.I.T. Petrescu and A. Apicella, 2016c. Smart-factory: Optimization and process control of composite centrifuged pipes. Am. J. Applied Sci., 13: 1330-1341. DOI: 10.3844/ajassp.2016.1330.1341

Aversa, R., F. Tamburrino, R.V. Petrescu, F.I.T. Petrescu and M. Artur et al., 2016d. Biomechanically inspired shape memory effect machines driven by muscle like acting NiTi alloys. Am. J. Applied Sci., 13: 1264-1271. DOI: 10.3844/ajassp.2016.1264.1271

Aversa, R., E.M. Buzea, R.V. Petrescu, A. Apicella and M. Neacsa et al., 2016e. Present a mechatronic system having able to determine the concentration of carotenoids. Am. J. Eng. Applied Sci., 9: 11061111. DOI: 10.3844/ajeassp.2016.1106.1111

Aversa, R., R.V. Petrescu, R. Sorrentino, F.I.T. Petrescu and A. Apicella, 2016f. Hybrid ceramo-polymeric nanocomposite for biomimetic scaffolds design and preparation. Am. J. Eng. Applied Sci., 9: 1096-1105. DOI: 10.3844/ajeassp.2016.1096.1105 
Aversa, R., V. Perrotta, R.V. Petrescu, C. Misiano and F.I.T. Petrescu et al., 2016g. From structural colors to super-hydrophobicity and achromatic transparent protective coatings: Ion plating plasma assisted $\mathrm{TiO} 2$ and $\mathrm{SiO} 2$ nano-film deposition. Am. J. Eng. Applied Sci., 9: 1037-1045.

DOI: 10.3844/ajeassp.2016.1037.1045

Aversa, R., R.V. Petrescu, F.I.T. Petrescu and A. Apicella, 2016h. Biomimetic and evolutionary design driven innovation in sustainable products development. Am. J. Eng. Applied Sci., 9: 1027-1036. DOI: 10.3844/ajeassp.2016.1027.1036

Aversa, R., R.V. Petrescu, A. Apicella and F.I.T. Petrescu, 2016i. Mitochondria are naturally micro robots - a review. Am. J. Eng. Applied Sci., 9: 991-1002. DOI: 10.3844/ajeassp.2016.991.1002

Aversa, R., R.V. Petrescu, A. Apicella and F.I.T. Petrescu, 2016j. We are addicted to vitamins $C$ and E-A review. Am. J. Eng. Applied Sci., 9: 1003-1018. DOI: 10.3844/ajeassp.2016.1003.1018

Aversa, R., R.V. Petrescu, A. Apicella and F.I.T. Petrescu, 2016k. Physiologic human fluids and swelling behavior of hydrophilic biocompatible hybrid ceramo-polymeric materials. Am. J. Eng. Applied Sci., 9: 962-972. DOI: 10.3844/ajeassp.2016.962.972

Aversa, R., R.V. Petrescu, A. Apicella and F.I.T. Petrescu, 20161. One can slow down the aging through antioxidants. Am. J. Eng. Applied Sci., 9: 1112-1126. DOI: 10.3844/ajeassp.2016.1112.1126

Aversa, R., R.V. Petrescu, A. Apicella and F.I.T. Petrescu, 2016m. About homeopathy or «Similia Similibus Curentur 》. Am. J. Eng. Applied Sci., 9: 1164-1172. DOI: 10.3844/ajeassp.2016.1164.1172

Aversa, R., R.V. Petrescu, A. Apicella and F.I.T. Petrescu, 2016n. The basic elements of life's. Am. J. Eng. Applied Sci., 9: 1189-1197.

DOI: 10.3844/ajeassp.2016.1189.1197

Aversa, R., F.I.T. Petrescu, R.V. Petrescu and A. Apicella, 2016o. Flexible stem trabecular prostheses. Am. J. Eng. Applied Sci., 9: 1213-1221. DOI: 10.3844 /ajeassp.2016.1213.122

Babayemi, A.K., 2016. Thermodynamics, non-linear isotherms, statistical modeling and optimization of phosphorus adsorption from wastewater. Am. J. Eng. Applied Sci., 9: 1019-1026. DOI: 10.3844/ajeassp.2016.1019.1026

Bakar, R.A., M.K. Mohammed and M.M. Rahman, 2009. Numerical study on the performance characteristics of hydrogen fueled port injection internal combustion engine. Am. J. Eng. Applied Sci., 2: 407-415. DOI: 10.3844/ajeassp.2009.407.415

Barone, G., A. Buonomano, C. Forzano and A. Palombo, 2016. WLHP systems in commercial buildings: A case study analysis based on a dynamic simulation approach. Am. J. Eng. Applied Sci., 9: 659-668. DOI: 10.3844/ajeassp.2016.659.668
Bedon, C., 2016. Review on the use of FRP composites for facades and building skins. Am. J. Eng. Applied Sci., 9: 713-723. DOI: 10.3844/ajeassp.2016.713.723

Bedon, C. and C. Amadio, 2016. A unified approach for the shear buckling design of structural glass walls with non-ideal restraints. Am. J. Eng. Applied Sci., 9: 64-78. DOI: 10.3844/ajeassp.2016.64.78

Bedon, C. and C. Louter, 2016. Finite-element numerical simulation of the bending performance of posttensioned structural glass beams with adhesively bonded CFRP tendons. Am. J. Eng. Applied Sci., 9: 680-691. DOI: 10.3844/ajeassp.2016.680.691

Bier, H. and S. Mostafavi, 2015. Structural optimization for materially informed design to robotic production processes. Am. J. Eng. Applied Sci., 8: 549-555. DOI: 10.3844/ajeassp.2015.549.555

Bolonkin, A., 2009a. Femtotechnology: Nuclear matter with fantastic properties. Am. J. Eng. Applied Sci., 2: 501-514. DOI: 10.3844/ajeassp.2009.501.514

Bolonkin, A., 2009b. Converting of matter to nuclear energy by ab-generator. Am. J. Eng. Applied Sci., 2: 683-693. DOI: 10.3844/ajeassp.2009.683.693

Boucetta, A., 2008. Vector control of a variable reluctance machine stator and rotor discs imbricates. Am. J. Eng. Applied Sci., 1: 260-265. DOI: 10.3844/ajeassp.2008.260.265

Bourahla, N. and A. Blakeborough, 2015. Similitude distortion compensation for a small scale model of a knee braced steel frame. Am. J. Eng. Applied Sci., 8: 481-488. DOI: 10.3844/ajeassp.2015.481.488

Bucinell, R.B., 2016. Stochastic model for variable amplitude fatigue induced delamination growth in graphite/epoxy laminates. Am. J. Eng. Applied Sci., 9: 635-646. DOI: 10.3844/ajeassp.2016.635.646

Budak, S., Z. Xiao, B. Johnson, J. Cole and M. Drabo et al., 2016. Highly-efficient advanced thermoelectric devices from different multilayer thin films. Am. J. Eng. Applied Sci., 9: 356-363. DOI: 10.3844 /ajeassp.2016.356.363

Buonomano, A., F. Calise and M. Vicidomini, 2016a. A novel prototype of a small-scale solar power plant: Dynamic simulation and thermoeconomic analysis. Am. J. Eng. Applied Sci., 9: 770-788. DOI: 10.3844/ajeassp.2016.770.788

Buonomano, A., F. Calise, M.D. d'Accadia, R. Vanoli and M. Vicidomini, 2016b. Simulation and experimental analysis of a demonstrative solar heating and cooling plant installed in Naples (Italy). Am. J. Eng. Applied Sci., 9: 798-813. DOI: 10.3844 /ajeassp.2016.798.813

Cao, W., H. Ding, Z. Bin and C. Ziming, 2013. New structural representation and digital-analysis platform for symmetrical parallel mechanisms. Int. J. Adv. Robotic Sys. DOI: 10.5772/56380 
Calise, F., M.D. dâ' Accadia, L. Libertini, E. Quiriti and M. Vicidomini, 2016b. Dynamic simulation and optimum operation strategy of a trigeneration system serving a hospital. Am. J. Eng. Applied Sci., 9: 854-867. DOI: 10.3844/ajeassp.2016.854.867

Campo, T., M. Cotto, F. Marquez, E. Elizalde and C. Morant, 2016. Graphene synthesis by plasmaenhanced CVD growth with ethanol. Am. J. Eng. Applied Sci., 9: 574-583.

DOI: 10.3844/ajeassp.2016.574.583

Cardu, M., P. Oreste and T. Cicala, 2009. Analysis of the tunnel boring machine advancement on the Bologna-Florence railway link. Am. J. Eng. Applied Sci., 2: 416-420.

DOI: 10.3844/ajeassp.2009.416.420

Casadei, D., 2015. Bayesian statistical inference for number counting experiments. Am. J. Eng. Applied Sci., 8: 730-735.

DOI: 10.3844/ajeassp.2015.730.735

Cataldo, R., 2006. Overview of planetary power system options for education. ITEA Human Exploration Project Authors, Glenn Research Center. Brooke Park, OH.

Chang, S.P., M.C. Chen and J.D. Lin, 2015. Study of heat-treated steel and related applications. Am. J. Eng. Applied Sci., 8: 611-619. DOI: 10.3844/ajeassp.2015.611.619

Chen, G. and L. Xu, 2016. A general strategy to enhance up conversion luminescence in rare-earth-ion-doped oxide nanocrystals. Am. J. Eng. Applied Sci., 9: 7983. DOI: 10.3844/ajeassp.2016.79.83

Chiozzi, A., G. Milani, N. Grillanda and A. Tralli, 2016. An adaptive procedure for the limit analysis of FRP reinforced masonry vaults and applications. Am. J. Eng. Applied Sci., 9: 735-745.

DOI: 10.3844/ajeassp.2016.735.745

Chisari, C. and C. Bedon, 2016. Multi-objective optimization of FRP jackets for improving the seismic response of reinforced concrete frames. Am. J. Eng. Applied Sci., 9: 669-679.

DOI: 10.3844/ajeassp.2016.669.679

Comanescu, A., 2010. Bazele Modelarii Mecanismelor. 1st Edn., E. Politeh, Press, Bucureşti, pp: 274.

Darabi, A., S.A. Soleamani and A. Hassannia, 2008. Fuzzy based digital automatic voltage regulator of a synchronous generator with unbalanced loads. Am. J. Eng. Applied Sci., 1: 280-286. DOI: 10.3844/ajeassp.2008.280.286

Daud, H., N. Yahya, A.A. Aziz and M.F. Jusoh, 2008. Development of wireless electric concept powering electrical appliances. Am. J. Eng. Applied Sci., 1: 12-15. DOI: 10.3844/ajeassp.2008.12.15

Demetriou, D., N. Nikitas and K.D. Tsavdaridis, 2015. Semi active tuned mass dampers of buildings: A simple control option. Am. J. Eng. Applied Sci., 8: 620-632. DOI: 10.3844/ajeassp.2015.620.632
Dixit, S. and S. Pal, 2015. Synthesis and characterization of ink (Carbon)-perovskite/polyaniline ternary composite electrode for sodium chloride separation. Am. J. Eng. Applied Sci., 8: 527-537. DOI: 10.3844 ajeassp.2015.527.537

Djalel, D., M. Mourad and H. Labar, 2013. New approach of electromagnetic fields of the lightning discharge. Am. J. Eng. Applied Sci., 6: 369-383. DOI: 10.3844 /ajeassp.2013.369.383

Dong, H., N. Giakoumidis, N. Figueroa and N. Mavridis, 2013. Approaching behaviour monitor and vibration indication in developing a General Moving Object Alarm System (GMOAS). Int. J. Adv. Robotic Sys. DOI: $10.5772 / 56586$

Ebrahim, N.A., S. Ahmed, S.H.A. Rashid and Z. Taha, 2012. Technology use in the virtual R\&D teams. Am. J. Eng. Applied Sci., 5: 9-14. DOI: 10.3844/ajeassp.2012.9.14

El-Labban, H.F., M. Abdelaziz and E.R.I. Mahmoud, 2013. Modification of carbon steel by laser surface melting: Part I: Effect of laser beam travelling speed on microstructural features and surface hardness. Am. J. Eng. Applied Sci., 6: 352-359. DOI: 10.3844/ajeassp.2013.352.359

Elliott, A., S. AlSalihi, A.L. Merriman and M.M. Basti, 2016. Infiltration of nanoparticles into porous binder jet printed parts. Am. J. Eng. Applied Sci., 9: 128133. DOI: 10.3844/ajeassp.2016.128.133

Elmeddahi, Y., H. Mahmoudi, A. Issaadi, M.F.A. Goosen and R. Ragab, 2016b. Evaluating the effects of climate change and variability on water resources: A case study of the cheliff Basin in Algeria. Am. J. Eng. Applied Sci., 9: 835-845. DOI: 10.3844/ajeassp.2016.835.845

El-Tous, Y., 2008. Pitch angle control of variable speed wind turbine. Am. J. Eng. Applied Sci., 1: 118-120. DOI: 10.3844 /ajeassp.2008.118.120

Faizal, A., S. Mulyono, R. Yendra and A. Fudholi, 2016. Design Maximum Power Point Tracking (MPPT) on photovoltaic panels using fuzzy logic method. Am. J. Eng. Applied Sci., 9: 789-797. DOI: 10.3844/ajeassp.2016.789.797

Farahani, A.S., N.M. Adam and M.K.A. Ariffin, 2010. Simulation of airflow and aerodynamic forces acting on a rotating turbine ventilator. Am. J. Eng. Applied Sci., 3: 159-170. DOI: 10.3844/ajeassp.2010.159.170

Farokhi, E. and M. Gordini, 2015. Investigating the parameters influencing the behavior of knee braced steel structures. Am. J. Eng. Applied Sci., 8: 567-574. DOI: 10.3844/ajeassp.2015.567.574

Fathallah, A.Z.M. and R.A. Bakar, 2009. Prediction studies for the performance of a single cylinder high speed spark ignition linier engine with spring mechanism as return cycle. Am. J. Eng. Applied Sci., 2: 713-720.

DOI: 10.3844/ajeassp.2009.713.720 
Fawcett, G.F. and J.N. Fawcett, 1974. Comparison of Polydyne and Non Polydyne Cams. In: Cams and Cam Mechanisms, Rees Jones, J. (Ed.), MEP, London and Birmingham, Alabama.

Fen, Y.W., W.M.M. Yunus, M.M. Moksin, Z.A. Talib and N.A. Yusof, 2011. Optical properties of crosslinked chitosan thin film with glutaraldehyde using surface Plasmon resonance technique. Am. J. Eng. Applied Sci., 4: 61-65.

DOI: 10.3844 /ajeassp.2011.61.65

Feraga, C.E., A. Moussaoui, A. Bouldjedri and A. Yousfi, 2009. Robust position controller for a permanent magnet synchronous actuator. Am. J. Eng. Applied Sci., 2: 388-392.

DOI: 10.3844 /ajeassp.2009.388.392

Franklin, D.J., 1930. Ingenious Mechanisms for Designers and Inventors. 1st Edn., Industrial Press Publisher.

Fu, Y.F., J. Gong, H. Huang, Y.J. Liu and D. Zhu et al., 2015. Parameters optimization of adaptive cashew shelling cutter based on BP neural network and genetic algorithm. Am. J. Eng. Applied Sci., 8: 648-658. DOI: 10.3844/ajeassp.2015.648.658

Gao, F., W.Z. Guo, Q.Y. Song and F.S. Du, 2010. Current development of heavy-duty manufacturing equipment. J. Mech. Eng., 46: 92-107.

Ge, H. and F. Gao, 2012. Type design for heavy-payload forging manipulators. Chinese J. Mech. Eng., 25: 197-205.

Ge, L. and X. Xu, 2015. A scheme design of cloud + end technology in demand side management. Am. J. Eng. Applied Sci., 8: 736-747.

DOI: 10.3844/ajeassp.2015.736.747

Giordana, F., V. Rognoni and G. Ruggieri, 1979. On the influence of measurement errors in the Kinematic analysis of cam. Mechanism Mach. Theory, 14: 327-340. DOI: $10.1016 / 0094-114 X(79) 90019-3$

Gruener, J.E., 2006. Lunar exploration (Presentation to ITEA Human Exploration Project Authors, November 2006, at Johnson Space Center). Houston, TX.

Gupta, P., A. Gupta and A. Asati, 2015. Ultra low power MUX based compressors for Wallace and Dadda multipliers in sub-threshold regime. Am. J. Eng. Applied Sci., 8: 702-716.

DOI: 10.3844/ajeassp.2015.702.716

Gusti, A.P. and Semin, 2016. The effect of vessel speed on fuel consumption and exhaust gas emissions. Am. J. Eng. Applied Sci., 9: 1046-1053. DOI: 10.3844/ajeassp.2016.1046.1053

Hain, K., 1971. Optimization of a cam mechanism to give good transmissibility maximal output angle of swing and minimal acceleration. J. Mechanisms, 6: 419-434. DOI: 10.1016/0022-2569(71)90044-9

Hassan, M., H. Mahjoub and M. Obed, 2012. Voicebased control of a DC servo motor. Am. J. Eng. Applied Sci., 5: 89-92.

DOI: 10.3844/ajeassp.2012.89.92
Hasan, S. and M.H. El-Naas, 2016. Optimization of a combined approach for the treatment of carbide slurry and capture of $\mathrm{CO}_{2}$. Am. J. Eng. Applied Sci., 9: 449-457. DOI: 10.3844/ajeassp.2016.449.457

Helmy, A.K. and G.S. El-Taweel, 2010. Neural network change detection model for satellite images using textural and spectral characteristics. Am. J. Eng. Applied Sci., 3: 604-610. DOI: 10.3844 ajeassp.2010.604.610

Hirun, W., 2016. Evaluation of interregional freight generation modelling methods by using nationwide commodity flow survey data. Am. J. Eng. Applied Sci., 9: 625-634. DOI: 10.3844/ajeassp.2016.625.634

Ho, C.Y.F., B.W.K. Ling, S.G. Blasi, Z.W. Chi and W.C. Siu, 2011. Single step optimal block matched motion estimation with motion vectors having arbitrary pixel precisions. Am. J. Eng. Applied Sci., 4: 448-460. DOI: 10.3844/ajeassp.2011.448.460

Huang, B., S.H. Masood, M. Nikzad, P.R. Venugopal and A. Arivazhagan, 2016. Dynamic mechanical properties of fused deposition modelling processed polyphenylsulfone material. Am. J. Eng. Applied Sci., 9: 1-11. DOI: 10.3844/ajeassp.2016.1.11

He, B., Z. Wang, Q. Li, H. Xie and R. Shen, 2013. An analytic method for the kinematics and dynamics of a multiple-backbone continuum robot. IJARS. DOI: $10.5772 / 54051$

Idarwazeh, S., 2011. Inverse discrete Fourier transformdiscrete Fourier transform techniques for generating and receiving spectrally efficient frequency division multiplexing signals. Am. J. Eng. Applied Sci., 4: 598-606. DOI: 10.3844/ajeassp.2011.598.606

Iqbal, 2016. An overview of Energy Loss Reduction (ELR) software used in Pakistan by WAPDA for calculating transformer overloading, line losses and energy losses. Am. J. Eng. Applied Sci., 9: 442-448. DOI: 10.3844/ajeassp.2016.442.448

Ismail, M.I.S., Y. Okamoto, A. Okada and Y. Uno, 2011. Experimental investigation on micro-welding of thin stainless steel sheet by fiber laser. Am. J. Eng. Applied Sci., 4: 314-320. DOI: 10.3844 /ajeassp.2011.314.320

Jaber, A.A. and R. Bicker, 2016. Industrial robot fault detection based on statistical control chart. Am. J. Eng. Applied Sci., 9: 251-263. DOI: 10.3844/ajeassp.2016.251.263

Jafari, N., A. Alsadoon, C.P. Withana, A. Beg and A. Elchouemi, 2016. Designing a comprehensive security framework for smartphones and mobile devices. Am. J. Eng. Applied Sci., 9: 724-734. DOI: 10.3844/ajeassp.2016.724.734

Jalil, M.I.A. and J. Sampe, 2013. Experimental investigation of thermoelectric generator modules with different technique of cooling system. Am. J. Eng. Applied Sci., 6: 1-7. DOI: 10.3844/ajeassp.2013.1.7 
Jaoude, A.A. and K. El-Tawil, 2013. Analytic and nonlinear prognostic for vehicle suspension systems. Am. J. Eng. Applied Sci., 6: 42-56. DOI: 10.3844 /ajeassp.2013.42.56

Jarahi, H., 2016. Probabilistic seismic hazard deaggregation for Karaj City (Iran). Am. J. Eng. Applied Sci., 9: 520-529. DOI: $10.3844 /$ ajeassp.2016.520.529

Jarahi, H. and S. Seifilaleh, 2016. Rock fall hazard zonation in Haraz Highway. Am. J. Eng. Applied Sci., 9: 371-379. DOI: $10.3844 /$ ajeassp.2016.371.379

Jauhari, K., A. Widodo and I. Haryanto, 2016. Identification of a machine tool spindle critical frequency through modal and imbalance response analysis. Am. J. Eng. Applied Sci., 9: 213-221. DOI: 10.3844/ajeassp.2016.213.221

Jiang, J., Q. Chen and S. Nimbalkar, 2016. Field data based method for predicting long-term settlements. Am. J. Eng. Applied Sci., 9: 466-476. DOI: 10.3844/ajeassp.2016.466.476

Jones, J.R. and J.E. Reeve, 1974. Dynamic Response of Cam Curves Based on Sinusoidal Segments. In: Cams and cam Mechanisms, Rees Jones, J. (Ed.), MEP, London and Birmingham, Alabama.

Kaewnai, S. and S. Wongwises, 2011. Improvement of the runner design of francis turbine using computational fluid dynamics. Am. J. Eng. Applied Sci., 4: 540-547.

DOI: 10.3844/ajeassp.2011.540.547

Khalifa, A.H.N., A.H. Jabbar and J.A. Muhsin, 2015. Effect of exhaust gas temperature on the performance of automobile adsorption airconditioner. Am. J. Eng. Applied Sci., 8: 575-581. DOI: 10.3844/ajeassp.2015.575.581

Khalil, R., 2015. Credibility of 3D volume computation using GIS for pit excavation and roadway constructions. Am. J. Eng. Applied Sci., 8: 434-442. DOI: 10.3844/ajeassp.2015.434.442

Kamble, V.G. and N. Kumar, 2016. Fabrication and tensile property analysis of polymer matrix composites of graphite and silicon carbide as fillers. Am. J. Eng. Applied Sci., 9: 17-30. DOI: 10.3844/ajeassp.2016.17.30

Kazakov, V.V., V.I. Yusupov, V.N. Bagratashvili, A.I. Pavlikov and V.A. Kamensky, 2016. Control of bubble formation at the optical fiber tip by analyzing ultrasound acoustic waves. Am. J. Eng. Applied Sci., 9: 921-927. DOI: 10.3844/ajeassp.2016.921.927

Kechiche, O.B.H.B., H.B.A. Sethom, H. Sammoud and I.S. Belkhodja, 2011. Optimized high-frequency signal injection based permanent magnet synchronous motor rotor position estimation applied to washing machines. Am. J. Eng. Applied Sci., 4: 390-399. DOI: 10.3844/ajeassp.2011.390.399
Koster, M.P., 1974. The Effects of Backlash and Shaft Flexibility on the Dynamic Behavior of a Cam Mechanism. In: Cams and Cam Mechanisms, Rees Jones, J. (Ed.), MEP, London and Birmingham, Alabama.

Kuli, I., T.M. Abu-Lebdeh, E.H. Fini and S.A. Hamoush, 2016. The use of nano-silica for improving mechanical properties of hardened cement paste. Am. J. Eng. Applied Sci., 9: 146-154. DOI: 10.3844 /ajeassp.2016.146.154

Kumar, N.D., R.D. Ravali and PR. Srirekha, 2015. Design and realization of pre-amplifier and filters for on-board radar system. Am. J. Eng. Applied Sci., 8: 689-701. DOI: 10.3844/ajeassp.2015.689.701

Kunanoppadon, J., 2010. Thermal efficiency of a combined turbocharger set with gasoline engine. Am. J. Eng. Applied Sci., 3: 342-349. DOI: 10.3844 /ajeassp.2010.342.349

Kwon, S., Y. Tani, H. Okubo and T. Shimomura, 2010. Fixed-star tracking attitude control of spacecraft using single-gimbal control moment gyros. Am. J. Eng. Applied Sci., 3: 49-55.

DOI: 10.3844 /ajeassp.2010.49.55

Lamarre, A., E.H. Fini and T.M. Abu-Lebdeh, 2016. Investigating effects of water conditioning on the adhesion properties of crack sealant. Am. J. Eng. Applied Sci., 9: 178-186. DOI: 10.3844 /ajeassp.2016.178.186

Lee, B.J., 2013. Geometrical derivation of differential kinematics to calibrate model parameters of flexible manipulator. Int. J. Adv. Robotic Sys.

DOI: $10.5772 / 55592$

Li, G. and D.S. Liu, 2010. Dynamic behavior of the forging manipulator under large amplitude compliance motion. J. Mech. Eng., 46: 21-28.

Li, R., B. Zhang, S. Xiu, H. Wang and L. Wang et al., 2015. Characterization of solid residues obtained from supercritical ethanol liquefaction of swine manure. Am. J. Eng. Applied Sci., 8: 465-470. DOI: 10.3844/ajeassp.2015.465.470

Lin, W., B. Li, X. Yang and D. Zhang, 2013. Modelling and control of inverse dynamics for a 5-DOF parallel kinematic polishing machine. Int. J. Adv. Robotic Sys. DOI: 10.5772/54966

Liu, H., W. Zhou, X. Lai and S. Zhu, 2013. An efficient inverse kinematic algorithm for a PUMA560structured robot manipulator. IJARS. DOI: $10.5772 / 56403$

Lubis, Z., A.N. Abdalla, Mortaza and R. Ghon, 2009. Mathematical modeling of the three phase induction motor couple to DC motor in hybrid electric vehicle. Am. J. Eng. Applied Sci., 2: 708-712. DOI: 10.3844 /ajeassp.2009.708.712

Madani, D.A. and A. Dababneh, 2016. Rapid entire body assessment: A literature review. Am. J. Eng. Applied Sci., 9: 107-118.

DOI: 10.3844/ajeassp.2016.107.118 
Malomar, G.E.B., A. Gueye, C. Mbow, V.B. Traore and A.C. Beye, 2016. Numerical study of natural convection in a square porous cavity thermally modulated on both side walls. Am. J. Eng. Applied Sci., 9: 591-598. DOI: 10.3844/ajeassp.2016.591.598

Mansour, M.A.A., 2016. Developing an anthropometric database for Saudi students and comparing Saudi dimensions relative to Turkish and Iranian peoples. Am. J. Eng. Applied Sci., 9: 547-557.

DOI: 10.3844/ajeassp.2016.547.557

Maraveas, C., Z.C. Fasoulakis and K.D. Tsavdaridis, 2015. A review of human induced vibrations on footbridges. Am. J. Eng. Applied Sci., 8: 422-433. DOI: 10.3844/ajeassp.2015.422.433

Marghany, M. and M. Hashim, 2009. Robust of doppler centroid for mapping sea surface current by using radar satellite data. Am. J. Eng. Applied Sci., 2: 781-788. DOI: 10.3844/ajeassp.2009.781.788

Martins, F.R., A.R. Gonçalves and E.B. Pereira, 2016. Observational study of wind shear in northeastern Brazil. Am. J. Eng. Applied Sci., 9: 484-504. DOI: 10.3844/ajeassp.2016.484.504

Marzuki, M.A.L.B., M.H. Abd Halim and A.R.N. Mohamed, 2015. Determination of natural frequencies through modal and harmonic analysis of space frame race car chassis based on ANSYS. Am. J. Eng. Applied Sci., 8: 538-548. DOI: 10.3844/ajeassp.2015.538.548

Mavukkandy, M.O., S. Chakraborty, T. Abbasi and S.A. Abbasi, 2016. A clean-green synthesis of platinum nanoparticles utilizing a pernicious weed lantana (Lantana Camara). Am. J. Eng. Applied Sci., 9: 8490. DOI: 10.3844 /ajeassp.2016.84.90

Minghini, F., N. Tullini and F. Ascione, 2016. Updating Italian design guide CNR DT-205/2007 in view of recent research findings: Requirements for pultruded FRP profiles. Am. J. Eng. Applied Sci., 9: 702-712. DOI: 10.3844/ajeassp.2016.702.712

Moezi, N., D. Dideban and A. Ketabi, 2008. A novel integrated SET based inverter for nano power electronic applications. Am. J. Eng. Applied Sci., 1: 219-222. DOI: 10.3844/ajeassp.2008.219.222

Mohamed, M.A., A.Y. Tuama, M. Makhtar, M.K. Awang and M. Mamat, 2016. The effect of RSA exponential key growth on the multi-core computational resource. Am. J. Eng. Applied Sci., 9: 1054-1061. DOI: 10.3844/ajeassp.2016.1054.1061

Mohan, K.S.R., P. Jayabalan and A. Rajaraman, 2012. Properties of fly ash based coconut fiber composite. Am. J. Eng. Applied Sci., 5: 29-34. DOI: 10.3844/ajeassp.2012.29.34

Mohseni, E. and K.D. Tsavdaridis, 2016. Effect of nanoalumina on pore structure and durability of class f fly ash self-compacting mortar. Am. J. Eng. Applied Sci., 9: 323-333. DOI: 10.3844/ajeassp.2016.323.333
Momani, M.A., T.A. Al Smadi, FM. Al Taweel and K.A. Ghaidan, 2011. GPS ionospheric total electron content and scintillation measurements during the October 2003 magnetic storm. Am. J. Eng. Applied Sci., 4: 301-306. DOI: 10.3844/ajeassp.2011.301.306

Momta, P.S., J.O. Omoboh and M.I. Odigi, 2015. Sedimentology and depositional environment of D2 sand in part of greater ughelli depobelt, onshore Niger Delta, Nigeria. Am. J. Eng. Applied Sci., 8: 556-566.

DOI: 10.3844/ajeassp.2015.556.566

Mondal, R., S. Sahoo and C.S. Rout, 2016. Mixed nickel cobalt manganese oxide nanorods for supercapacitor application. Am. J. Eng. Applied Sci., 9: 540-546. DOI: 10.3844 /ajeassp.2016.540.546

Montgomery, J., T.M. Abu-Lebdeh, S.A. Hamoush and M. Picornell, 2016. Effect of nano-silica on the compressive strength of harden cement paste at different stages of hydration. Am. J. Eng. Applied Sci., 9: 166-177. DOI: 10.3844 ajeassp.2016.166.177

Moretti, M.L., 2015. Seismic design of masonry and reinforced concrete infilled frames: A comprehensive overview. Am. J. Eng. Applied Sci., 8: 748-766. DOI: 10.3844/ajeassp.2015.748.766

Morse, A., M.M. Mansfield, R.M. Alley, H.A. Kerr and R.B. Bucinell, 2016b. Traction enhancing products affect maximum torque at the shoe-floor interface: A potential increased risk of ACL injury. Am. J. Eng. Applied Sci., 9: 889-893.

DOI: 10.3844 /ajeassp.2016.889.893

Moubarek, T. and A. Gharsallah, 2016. A six-port reflectometer calibration using Wilkinson power divider. Am. J. Eng. Applied Sci., 9: 274-280. DOI: 10.3844/ajeassp.2016.274.280

Nabilou, A., 2016a. Effect of parameters of selection and replacement drilling bits based on geo-mechanical factors: (Case study: Gas and oil reservoir in the Southwest of Iran). Am. J. Eng. Applied Sci., 9: 380-395. DOI: 10.3844/ajeassp.2016.380.395

Nabilou, A., 2016b. Study of the parameters of Steam Assisted Gravity Drainage (SAGD) method for enhanced oil recovery in a heavy oil fractured carbonate reservoir. Am. J. Eng. Applied Sci., 9: 647-658. DOI: 10.3844/ajeassp.2016.647.658

Nachiengtai, T., W. Chim-Oye, S. Teachavorasinskun and W. Sa-Ngiamvibool, 2008. Identification of shear band using elastic shear wave propagation. Am. J. Eng. Applied Sci., 1: 188-191. DOI: 10.3844 ajeassp.2008.188.191

Nahas, R. and S.P. Kozaitis, 2014. Metric for the fusion of synthetic and real imagery from multimodal sensors. Am. J. Eng. Applied Sci., 7: 355-362. DOI: 10.3844 /ajeassp.2014.355.362 
Nandhakumar, S., V. Selladurai and S. Sekar, 2009. Numerical investigation of an industrial robot arm control problem using haar wavelet series. Am. J. Eng. Applied Sci., 2: 584-589.

DOI: 10.3844/ajeassp.2009.584.589

Ng, K.C., M.Z. Yusoff, K. Munisamy, H. Hasini and N.H. Shuaib, 2008. Time-marching method for computations of high-speed compressible flow on structured and unstructured grid. Am. J. Eng. Applied Sci., 1: 89-94. DOI: 10.3844/ajeassp.2008.89.94

Obaiys, S.J., Z. Abbas, N.M.A. Nik Long, A.F. Ahmad and A. Ahmedov et al., 2016. On the general solution of first-kind hypersingular integral equations. Am. J. Eng. Applied Sci., 9: 195-201. DOI: 10.3844/ajeassp.2016.195.201

Odeh, S., R. Faqeh, L. Abu Eid and N. Shamasneh, 2009. Vision-based obstacle avoidance of mobile robot using quantized spatial model. Am. J. Eng. Applied Sci., 2: 611-619.

DOI: 10.3844/ajeassp.2009.611.619

Ong, A.T., A. Mustapha, Z.B. Ibrahim, S. Ramli and B.C. Eong, 2015. Real-time automatic inspection system for the classification of PCB flux defects. Am. J. Eng. Applied Sci., 8: 504-518. DOI: 10.3844 /ajeassp.2015.504.518

Opafunso, Z.O., I.I. Ozigis and I.A. Adetunde, 2009. Pneumatic and hydraulic systems in coal fluidized bed combustor. Am. J. Eng. Applied Sci., 2: 88-95. DOI: 10.3844/ajeassp.2009.88.95

Orlando, N. and E. Benvenuti, 2016. Advanced XFEM simulation of pull-out and debonding of steel bars and FRP-reinforcements in concrete beams. Am. J. Eng. Applied Sci., 9: 746-754. DOI: 10.3844/ajeassp.2016.746.754

Pannirselvam, N., P.N. Raghunath and K. Suguna, 2008. Neural network for performance of glass fibre reinforced polymer plated RC beams. Am. J. Eng. Applied Sci., 1: 82-88.

DOI: 10.3844/ajeassp.2008.82.88

Pattanasethanon, S., 2010. The solar tracking system by using digital solar position sensor. Am. J. Eng. Applied Sci., 3: 678-682. DOI: 10.3844/ajeassp.2010.678.682

Pérez-de León, G., V.E. Lamberti, R.D. Seals, T.M. Abu-Lebdeh and S.A. Hamoush, 2016. Gas atomization of molten metal: Part I. Numerical modeling conception. Am. J. Eng. Applied Sci., 9: 303-322. DOI: 10.3844/ajeassp.2016.303.322

Padula, F. and V. Perdereau, 2013. An on-line path planner for industrial manipulators. Int. J. Adv. Robotic Sys. DOI: 10.5772/55063

Perumaal, S. and N. Jawahar, 2013. Automated trajectory planner of industrial robot for pick-andplace task. IJARS. DOI: 10.5772/53940

Petrescu, F. and R. Petrescu, 1995a. Contributions to optimization of the polynomial motion laws of the stick from the internal combustion engine distribution mechanism. Bucharest, 1: 249-256.
Petrescu, F. and R. Petrescu, 1995b. Contributions to the synthesis of internal combustion engine distribution mechanisms. Bucharest, 1: 257-264.

Petrescu, F. and R. Petrescu, 1997a. Dynamics of cam mechanisms (exemplified on the classic distribution mechanism). Bucharest, 3: 353-358.

Petrescu, F. and R. Petrescu, 1997b. Contributions to the synthesis of the distribution mechanisms of internal combustion engines with a Cartesian coordinate method. Bucharest, 3: 359-364.

Petrescu, F. and R. Petrescu, 1997c. Contributions to maximizing polynomial laws for the active stroke of the distribution mechanism from internal combustion engines. Bucharest, 3: 365-370.

Petrescu, F. and R. Petrescu, 2000a. Synthesis of distribution mechanisms by the rectangular (Cartesian) coordinate method. Proceedings of the 8th National Conference on International Participation, (CIP' 00), Craiova, Romania, pp: 297-302.

Petrescu, F. and R. Petrescu, 2000b. The design (synthesis) of cams using the polar coordinate method (triangle method). Proceedings of the 8th National Conference on International Participation, (CIP' 00), Craiova, Romania, pp: 291-296.

Petrescu, F. and R. Petrescu, 2002a. Motion laws for cams. Proceedings of the International Computer Assisted Design, National Symposium with Participation, (SNP' 02), Braşov, pp: 321-326.

Petrescu, F. and R. Petrescu, 2002b. Camshaft dynamics elements. Proceedings of the International Computer Assisted Design, National Participation Symposium, (SNP' 02), Braşov, pp: 327-332.

Petrescu, F. and R. Petrescu, 2003. Some elements regarding the improvement of the engine design. Proceedings of the National Symposium, Descriptive Geometry, Technical Graphics and Design, (GTD' 03), Braşov, pp: 353-358.

Petrescu, F. and R. Petrescu, 2005a. The cam design for a better efficiency. Proceedings of the International Conference on Engineering Graphics and Design, (EGD' 05), Bucharest, pp: 245-248.

Petrescu, F. and R. Petrescu, 2005b. Contributions at the dynamics of cams. Proceedings of the 9th IFToMM International Symposium on Theory of Machines and Mechanisms, (TMM' 05), Bucharest, Romania, pp: 123-128.

Petrescu, F. and R. Petrescu, 2005c. Determining the dynamic efficiency of cams. Proceedings of the 9th IFToMM International Symposium on Theory of Machines and Mechanisms, (TMM' 05), Bucharest, Romania, pp: 129-134.

Petrescu, F. and R. Petrescu, 2005d. An original internal combustion engine. Proceedings of the 9th IFToMM International Symposium on Theory of Machines and Mechanisms, (TMM' 05), Bucharest, Romania, pp: 135-140. 
Petrescu, F. and R. Petrescu, 2005e. Determining the mechanical efficiency of Otto engine's mechanism. Proceedings of the 9th IFToMM International Symposium on Theory of Machines and Mechanisms, (TMM 05), Bucharest, Romania, pp: 141-146.

Petrescu, F.I. and R.V. Petrescu, 2011a. Mechanical Systems, Serial and Parallel (Romanian). 1st Edn., LULU Publisher, London, UK, pp: 124.

Petrescu, FIT., Petrescu, RV., 2011 b. Trenuri Planetare. 1st Edn., Createspace Independent Pub., ISBN-13: 978-1468030419, pp: 104.

Petrescu, F.I. and R.V. Petrescu, 2012a. Kinematics of the planar quadrilateral mechanism. ENGEVISTA, 14: $345-348$

Petrescu, F.I. and R.V. Petrescu, 2012b. MecatronicaSisteme Seriale si Paralele. 1st Edn., Create Space Publisher, USA, pp: 128.

Petrescu, F.I. and R.V. Petrescu, 2013a. Cinematics of the 3R dyad. ENGEVISTA, 15: 118-124.

Petrescu, F.I.T. and R.V. Petrescu, 2013b. Forces and efficiency of cams. Int. Rev. Mech. Eng., 7: 507-511.

Petrescu, F.I.T. and R.V. Petrescu, 2013c. Cams with high efficiency. Int. Rev. Mech. Eng., 7: 599-606.

Petrescu, F.I.T. and R.V. Petrescu, 2013d. An algorithm for setting the dynamic parameters of the classic distribution mechanism. Int. Rev. Modell. Simulat., 6: 1637-1641.

Petrescu, F.I.T. and R.V. Petrescu, 2013e. Dynamic synthesis of the rotary cam and translated tappet with roll. Int. Rev. Modell. Simulat., 6: 600-607.

Petrescu, F.I.T. and R.V. Petrescu, 2014a. Parallel moving mechanical systems. Independent $\mathrm{J}$. Manage. Product., 5: 564-580.

Petrescu, F.I.T. and R.V. Petrescu, 2014b. Cam gears dynamics in the classic distribution. Independent $\mathrm{J}$. Manage. Product., 5: 166-185.

Petrescu, F.I.T. and R.V. Petrescu, 2014c. Highefficiency gears synthesis by avoid the interferences. Independent J. Manage. Product., 5: 275-298.

Petrescu, F.I.T. and R.V. Petrescu, 2014d. Gear design. J. ENGEVISTA, 16: 313-328.

Petrescu, F.I.T. and R.V. Petrescu, 2014e. Kinetostatic of the $3 \mathrm{R}$ dyad (or $2 \mathrm{R}$ module). J. ENGEVISTA, 16: 314-321.

Petrescu, F.I.T. and R.V. Petrescu, 2014f. Balancing Otto engines. Int. Rev. Mech. Eng., 8: 473-480.

Petrescu, F.I.T. and R.V. Petrescu, 2014g. Machine equations to the classical distribution. Int. Rev. Mech. Eng., 8: 309-316.

Petrescu, F.I.T. and R.V. Petrescu, 2014h. Forces of internal combustion heat engines. Int. Rev. Modell. Simulat., 7: 206-212.

Petrescu, F.I.T. and R.V. Petrescu, 2014i. Determination of the yield of internal combustion thermal engines. Int. Rev. Mech. Eng., 8: 62-67.
Petrescu, F.I.T. and R.V. Petrescu, 2015a. Forces at the main mechanism of a railbound forging manipulator. Independent J. Manage. Product., 6: 904-921.

Petrescu, F.I.T. and R.V. Petrescu, 2015b. Kinematics at the main mechanism of a railbound forging manipulator. Independent J. Manage. Product., 6: 711-729.

Petrescu, F.I.T. and R.V. Petrescu, 2015c. Machine motion equations. Independent J. Manage. Product., 6: 773-802.

Petrescu F.I.T. and R.V. Petrescu, 2015d. Presenting a railbound forging manipulator. Applied Mech. Mater., 762: 219-224.

Petrescu, F.I.T. and R.V. Petrescu, 2015e. About the anthropomorphic robots. J. ENGEVISTA, 17: 1-15.

Petrescu, F.I. and R.V. Petrescu, 2016a. Parallel moving mechanical systems kinematics. ENGEVISTA, 18: 455-491.

Petrescu, F.I. and R.V. Petrescu, 2016b. Direct and inverse kinematics to the anthropomorphic robots. ENGEVISTA, 18: 109-124.

Petrescu, F.I. and R.V. Petrescu, 2016c. Dynamic cinematic to a structure 2R. Revista Geintec-Gestao Inovacao E Tecnol., 6: 3143-3154.

Petrescu, FIT. and R.V. Petrescu, 2016d. An Otto engine dynamic model. Independent J. Manage. Product., 7: 038-048

Petrescu, R.V., R. Aversa, A. Apicella and F.I. Petrescu, 2016. Future medicine services robotics. Am. J. Eng. Applied Sci., 9: 1062-1087.

DOI: 10.3844/ajeassp.2016.1062.1087

Petrescu, F.I., B. Grecu, A. Comanescu and R.V. Petrescu, 2009. Some mechanical design elements. Proceeding of the International Conference on Computational Mechanics and Virtual Engineering, (MVE' 09), Braşov, pp: 520-525.

Petrescu, F.I.T., 2008. Ph.D. Thesis, „Theoretical and Applied Contributions About the Dynamic of Planar Mechanisms with Superior Linkages". Bucharest Polytechnic University.

Petrescu, F.I.T., 2011. Teoria Mecanismelor si a Masinilor: Curs Si Aplicatii. 1st Edn., CreateSpace Independent Publishing Platform. ISBN-10: 1468015826. pp: 432.

Petrescu, F.I.T., 2015a. Geometrical synthesis of the distribution mechanisms. Am. J. Eng. Applied Sci., 8: 63-81. DOI: 10.3844/ajeassp.2015.63.81

Petrescu, F.I.T., 2015b. Machine motion equations at the internal combustion heat engines. Am. J. Eng. Applied Sci., 8: 127-137. DOI: 10.3844/ajeassp.2015.127.137

Petrescu, F.I.T., A. Apicella, A. Raffaella, RV. Petrescu and J.K. Calautit et al., 2016. Something about the mechanical moment of inertia. Am. J. Applied Sci., 13: 1085-1090. DOI: 10.3844/ajassp.2016.1085.1090

Petrescu, R.V., R. Aversa, B. Akash, R. Bucinell and J. Corchado et al., 2017a. Yield at thermal engines internal combustion. Am. J. Eng. Applied Sci., 10: 243-251. DOI: 10.3844/ajeassp.2017.243.251 
Petrescu, R.V., R. Aversa, B. Akash, B. Ronald and J. Corchado et al., 2017b. Velocities and accelerations at the 3R mechatronic systems. Am. J. Eng. Applied Sci., 10: 252-263. DOI: 10.3844/ajeassp.2017.252.263

Petrescu, R.V., R. Aversa, B. Akash, R. Bucinell and J. Corchado et al., 2017c. Anthropomorphic solid structures n-r kinematics. Am. J. Eng. Applied Sci., 10: 279-291. DOI: 10.3844/ajeassp.2017.279.291

Petrescu, R.V., R. Aversa, B. Akash, R. Bucinell and J. Corchado et al., 2017d. Inverse kinematics at the anthropomorphic robots, by a trigonometric method. Am. J. Eng. Applied Sci., 10: 394-411.

DOI: 10.3844/ajeassp.2017.394.411

Petrescu, R.V., R. Aversa, B. Akash, R. Bucinell and J. Corchado et al., 2017e. Forces at internal combustion engines. Am. J. Eng. Applied Sci., 10: 382-393. DOI: 10.3844/ajeassp.2017.382.393

Petrescu, R.V., R. Aversa, B. Akash, R. Bucinell and J. Corchado et al., 2017f. Gears-Part I. Am. J. Eng. Applied Sci., 10: 457-472.

DOI: 10.3844/ajeassp.2017.457.472

Petrescu, R.V., R. Aversa, B. Akash, R. Bucinell and J. Corchado et al., 2017g. Gears-part II. Am. J. Eng. Applied Sci., 10: 473-483.

DOI: 10.3844 /ajeassp.2017.473.483

Petrescu, R.V., R. Aversa, B. Akash, R. Bucinell and J. Corchado et al., 2017h. Cam-gears forces, velocities, powers and efficiency. Am. J. Eng. Applied Sci., 10: 491-505.

DOI: 10.3844/ajeassp.2017.491.505

Petrescu, R.V., R. Aversa, B. Akash, R. Bucinell and J. Corchado et al., 2017i. Dynamics of mechanisms with cams illustrated in the classical distribution. Am. J. Eng. Applied Sci., 10: 551-567. DOI: 10.3844/ajeassp.2017.551.567

Petrescu, R.V., R. Aversa, B. Akash, R. Bucinell and J. Corchado et al., 2017j. Testing by non-destructive control. Am. J. Eng. Applied Sci., 10: 568-583. DOI: 10.3844/ajeassp.2017.568.583

Petrescu, R.V., R. Aversa, A. Apicella and F.I.T. Petrescu, 2017k. Transportation engineering. Am. J. Eng. Applied Sci., 10: 685-702.

DOI: 10.3844/ajeassp.2017.685.702

Petrescu, R.V., R. Aversa, S. Kozaitis, A. Apicella and F.I.T. Petrescu, 2017l. The quality of transport and environmental protection, part I. Am. J. Eng. Applied Sci., 10: 738-755. DOI: 10.3844/ajeassp.2017.738.755

Petrescu, R.V., R. Aversa, B. Akash, R. Bucinell and J. Corchado et al., $2017 \mathrm{~m}$. Modern propulsions for aerospace-a review. J. Aircraft Spacecraft Technol., 1: 1-8. DOI: $10.3844 /$ jastsp.2017.1.8

Petrescu, R.V., R. Aversa, B. Akash, R. Bucinell and J. Corchado et al., 2017n. Modern propulsions for aerospace-part II. J. Aircraft Spacecraft Technol., 1: 9-17. DOI: $10.3844 /$ jastsp.2017.9.17
Petrescu, R.V., R. Aversa, B. Akash, R. Bucinell and J. Corchado et al., 2017o. History of aviation-a short review. J. Aircraft Spacecraft Technol., 1: 30-49. DOI: 10.3844 /jastsp.2017.30.49

Petrescu, R.V., R. Aversa, B. Akash, R. Bucinell and J. Corchado et al., 2017p. Lockheed martin-a short review. J. Aircraft Spacecraft Technol., 1: 50-68. DOI: 10.3844 /jastsp.2017.50.68

Petrescu, R.V., R. Aversa, B. Akash, J. Corchado and F. Berto et al., 2017q. Our universe. J. Aircraft Spacecraft Technol., 1: 69-79. DOI: 10.3844 jastsp.2017.69.79

Petrescu, R.V., R. Aversa, B. Akash, J. Corchado and F. Berto et al., 2017r. What is a UFO? J. Aircraft Spacecraft Technol., 1: 80-90. DOI: 10.3844 jastsp.2017.80.90

Petrescu, R.V., R. Aversa, B. Akash, J. Corchado and F. Berto et al., 2017s. About bell helicopter FCX-001 concept aircraft-a short review. J. Aircraft Spacecraft Technol., 1: 91-96. DOI: 10.3844/jastsp.2017.91.96

Petrescu, R.V., R. Aversa, B. Akash, J. Corchado and F. Berto et al., 2017t. Home at airbus. J. Aircraft Spacecraft Technol., 1: 97-118. DOI: $10.3844 /$ jastsp.2017.97.118

Petrescu, R.V., R. Aversa, B. Akash, J. Corchado and F. Berto et al., 2017u. Airlander. J. Aircraft Spacecraft Technol., 1: 119-148. DOI: 10.3844 /jastsp.2017.119.148

Petrescu, R.V., R. Aversa, B. Akash, J. Corchado and F. Berto et al., 2017v. When boeing is dreaming-a review. J. Aircraft Spacecraft Technol., 1: 149-161. DOI: 10.3844/jastsp.2017.149.161

Petrescu, R.V., R. Aversa, B. Akash, J. Corchado and F. Berto et al., 2017w. About Northrop Grumman. J. Aircraft Spacecraft Technol., 1: 162-185. DOI: $10.3844 /$ jastsp.2017.162.185

Petrescu, R.V., R. Aversa, B. Akash, J. Corchado and F. Berto et al., 2017x. Some special aircraft. J. Aircraft Spacecraft Technol., 1: 186-203. DOI: $10.3844 /$ jastsp.2017.186.203

Petrescu, R.V., R. Aversa, B. Akash, J. Corchado and F. Berto et al., 2017y. About helicopters. J. Aircraft Spacecraft Technol., 1: 204-223. DOI: $10.3844 /$ jastsp.2017.204.223

Petrescu, R.V., R. Aversa, B. Akash, F. Berto and A. Apicella et al., 2017z. The modern flight. J. Aircraft Spacecraft Technol., 1: 224-233. DOI: $10.3844 /$ jastsp.2017.224.233

Petrescu, R.V., R. Aversa, B. Akash, F. Berto and A. Apicella et al., 2017aa. Sustainable energy for aerospace vessels. J. Aircraft Spacecraft Technol., 1: 234-240. DOI: 10.3844/jastsp.2017.234.240

Petrescu, R.V., R. Aversa, B. Akash, F. Berto and A. Apicella et al., 2017ab. Unmanned helicopters. J. Aircraft Spacecraft Technol., 1: 241-248. DOI: $10.3844 /$ jastsp.2017.241.248 
Petrescu, R.V., R. Aversa, B. Akash, F. Berto and A. Apicella et al., 2017ac. Project HARP. J. Aircraft Spacecraft Technol., 1: 249-257.

DOI: $10.3844 /$ jastsp.2017.249.257

Petrescu, R.V., R. Aversa, B. Akash, F. Berto and A. Apicella et al., 2017ad. Presentation of Romanian engineers who contributed to the development of global aeronautics-part I. J. Aircraft Spacecraft Technol., 1: 258-271.

DOI: 10.3844 /jastsp.2017.258.271

Petrescu, R.V., R. Aversa, B. Akash, F. Berto and A. Apicella et al., 2017ae. A first-class ticket to the planet mars, please. J. Aircraft Spacecraft Technol., 1: 272-281. DOI: 10.3844/jastsp.2017.272.281

Petrescu, R.V., R. Aversa, A. Apicella, M.M. Mirsayar and S. Kozaitis et al., 2018a. NASA started a propeller set on board voyager 1 after 37 years of break. Am. J. Eng. Applied Sci., 11: 66-77. DOI: 10.3844/ajeassp.2018.66.77

Petrescu, R.V., R. Aversa, A. Apicella, M.M. Mirsayar and S. Kozaitis et al., 2018b. There is life on mars? Am. J. Eng. Applied Sci., 11: 78-91. DOI: 10.3844/ajeassp.2018.78.91

Petrescu, R.V., R. Aversa, A. Apicella and F.I.T. Petrescu, 2018c. Friendly environmental transport. Am. J. Eng. Applied Sci., 11: 154-165. DOI: 10.3844/ajeassp.2018.154.165

Petrescu, R.V., R. Aversa, B. Akash, T.M. Abu-Lebdeh and A. Apicella et al., 2018d. Buses running on gas. Am. J. Eng. Applied Sci., 11: 186-201. DOI: 10.3844/ajeassp.2018.186.201

Petrescu, R.V., R. Aversa, B. Akash, T.M. Abu-Lebdeh and A. Apicella et al., 2018e. Some aspects of the structure of planar mechanisms. Am. J. Eng. Applied Sci., 11: 245-259. DOI: 10.3844/ajeassp.2018.245.259

Petrescu, RV., R. Aversa, T.M. Abu-Lebdeh, A. Apicella and F.I.T. Petrescu, 2018f. The forces of a simple carrier manipulator. Am. J. Eng. Applied Sci., 11: 260-272. DOI: 10.3844/ajeassp.2018.260.272

Petrescu, RV., R. Aversa, T.M. Abu-Lebdeh, A. Apicella and F.I.T. Petrescu, 2018g. The dynamics of the otto engine. Am. J. Eng. Applied Sci., 11: 273-287.

DOI: 10.3844/ajeassp.2018.273.287

Petrescu, RV., R. Aversa, T.M. Abu-Lebdeh, A. Apicella and F.I.T. Petrescu, 2018h. NASA satellites help us to quickly detect forest fires. Am. J. Eng. Applied Sci., 11: 288-296. DOI: 10.3844/ajeassp.2018.288.296

Petrescu, RV., R. Aversa, T.M. Abu-Lebdeh, A. Apicella and F.I.T. Petrescu, 2018i. Kinematics of a mechanism with a triad. Am. J. Eng. Applied Sci., 11: 297-308. DOI: 10.3844/ajeassp.2018.297.308

Petrescu, R.V., R. Aversa, A. Apicella and F.I.T. Petrescu, 2018j. Romanian engineering "on the wings of the wind". J. Aircraft Spacecraft Technol., 2: 1-18. DOI: $10.3844 /$ jastsp.2018.1.18
Petrescu, R.V., R. Aversa, A. Apicella and F.I.T. Petrescu, 2018k. NASA Data used to discover eighth planet circling distant star. J. Aircraft Spacecraft Technol., 2: 19-30.

DOI: $10.3844 /$ jastsp.2018.19.30

Petrescu, R.V., R. Aversa, A. Apicella and F.I.T. Petrescu, 20181. NASA has found the most distant black hole. J. Aircraft Spacecraft Technol., 2: 31-39. DOI: $10.3844 /$ jastsp.2018.31.39

Petrescu, R.V., R. Aversa, A. Apicella and F.I.T. Petrescu, 2018m. Nasa selects concepts for a new mission to titan, the moon of saturn. J. Aircraft Spacecraft Technol., 2: 40-52. DOI: 10.3844 jastsp.2018.40.52

Petrescu, R.V., R. Aversa, A. Apicella and F.I.T. Petrescu, 2018n. NASA sees first in 2018 the direct proof of ozone hole recovery. J. Aircraft Spacecraft Technol., 2: 53-64. DOI: 10.3844/jastsp.2018.53.64

Pisello, A.L., G. Pignatta, C. Piselli, V.L. Castaldo and F. Cotana, 2016. Investigating the dynamic thermal behavior of building envelope in summer conditions by means of in-field continuous monitoring. Am. J. Eng. Applied Sci., 9: 505-519.

DOI: 10.3844/ajeassp.2016.505.519

Pourmahmoud, N., 2008. Rarefied gas flow modeling inside rotating circular cylinder. Am. J. Eng. Applied Sci., 1: 62-65.

DOI: 10.3844/ajeassp.2008.62.65

Pravettoni, M., C.S.P. Lòpez and R.P. Kenny, 2016. Impact of the edges of a backside diffusive reflector on the external quantum efficiency of luminescent solar concentrators: Experimental and computational approach. Am. J. Eng. Applied Sci., 9: 53-63.

DOI: 10.3844 /ajeassp.2016.53.63

Qutbodin, K., 2010. Merging autopilot/flight control and navigation-flight management systems. Am. J. Eng. Applied Sci., 3: 629-630.

DOI: 10.3844/ajeassp.2010.629.630

Rajbhandari, S., Z. Ghassemlooy and M. Angelova, 2011. The performance of a dual header pulse interval modulation in the presence of artificial light interferences in an indoor optical wireless communications channel with wavelet denoising. Am. J. Eng. Applied Sci., 4: 513-519. DOI: 10.3844/ajeassp.2011.513.519

Rajput, R.S., S. Pandey and S. Bhadauria, 2016. Correlation of biodiversityA of algal genera with special reference to the waste water effluents from industries. Am. J. Eng. Applied Sci., 9: 1127-1133. DOI: 10.3844/ajeassp.2016.1127.1133

Rajupillai, K., S. Palaniammal and K. Bommuraju, 2015. Computational intelligence and application of frame theory in communication systems. Am. J. Eng. Applied Sci., 8: 633-637.

DOI: 10.3844/ajeassp.2015.633.637 
Raptis, K.G., G.A. Papadopoulos, T.N. Costopoulos and A.D. Tsolakis, 2011. Experimental study of load sharing in roller-bearing contact by caustics and photoelasticity. Am. J. Eng. Applied Sci., 4: 294-300. DOI: 10.3844/ajeassp.2011.294.300

Rama, G., D. Marinkovic and M. Zehn, 2016. Efficient co-rotational 3-node shell element. Am. J. Eng. Applied Sci., 9: 420-431.

DOI: 10.3844/ajeassp.2016.420.431

Rea, P. and E. Ottaviano, 2016. Analysis and mechanical design solutions for sit-to-stand assisting devices. Am. J. Eng. Applied Sci., 9: 1134-1143. DOI: 10.3844/ajeassp.2016.1134.1143

Rhode-Barbarigos, L., V. Charpentier, S. Adriaenssens and O. Baverel, 2015. Dialectic form finding of structurally integrated adaptive structures. Am. J. Eng. Applied Sci., 8: 443-454. DOI: 10.3844/ajeassp.2015.443.454

Riccio, A., U. Caruso, A. Raimondo and A. Sellitto, 2016a. Robustness of XFEM method for the simulation of cracks propagation in fracture mechanics problems. Am. J. Eng. Applied Sci., 9: 599-610. DOI: 10.3844/ajeassp.2016.599.610

Riccio, A., R. Cristiano and S. Saputo, 2016b. A brief introduction to the bird strike numerical simulation. Am. J. Eng. Applied Sci., 9: 946-950. DOI: 10.3844 /ajeassp.2016.946.950

Rich, F. and M.A. Badar, 2016. Statistical analysis of auto dilution Vs manual dilution process in inductively coupled plasma spectrometer tests. Am. J. Eng. Applied Sci., 9: 611-624. DOI: 10.3844/ajeassp.2016.611.624

Rohit, K. and S. Dixit, 2016. Mechanical properties of waste Biaxially Oriented Polypropylene metallized films (BOPP), LLDPE: LDPE films with sisal fibres. Am. J. Eng. Applied Sci., 9: 913-920. DOI: 10.3844/ajeassp.2016.913.920

Rulkov, N.F., A.M. Hunt, P.N. Rulkov and A.G. Maksimov, 2016. Quantization of map-based neuronal model for embedded simulations of neurobiological networks in real-time. Am. J. Eng. Applied Sci., 9: 973-984. DOI: 10.3844/ajeassp.2016.973.984

Saikia, A. and N. Karak, 2016. Castor oil based epoxy/clay nanocomposite for advanced applications. Am. J. Eng. Applied Sci., 9: 31-40. DOI: 10.3844 /ajeassp.2016.31.40

Sallami, A., N. Zanzouri and M. Ksouri, 2016. Robust diagnosis of a DC motor by bond graph approach. Am. J. Eng. Applied Sci., 9: 432-438.

DOI: 10.3844 /ajeassp.2016.432.438

Samantaray, K.S., S. Sahoo and C.S. Rout, 2016. Hydrothermal synthesis of CuWO4-reduced graphene oxide hybrids and supercapacitor application. Am. J. Eng. Applied Sci., 9: 584-590. DOI: 10.3844/ajeassp.2016.584.590
Santos, F.A. and C. Bedon, 2016. Preliminary experimental and finite-element numerical assessment of the structural performance of SMAreinforced GFRP systems. Am. J. Eng. Applied Sci., 9: 692-701. DOI: 10.3844/ajeassp.2016.692.701

Sava, I., 1970. Contributions to dynamics and optimization of income mechanism synthesis. Ph.D. Thesis, I.P.B.

Semin, A.R. Ismail and R.A. Bakar, 2009a. Combustion temperature effect of diesel engine convert to compressed natural gas engine. Am. J. Eng. Applied Sci., 2: 212-216. DOI: 10.3844/ajeassp.2009.212.216

Semin, A.R. Ismail and R.A. Bakar, 2009b. Effect of diesel engine converted to sequential port injection compressed natural gas engine on the cylinder pressure Vs crank angle in variation engine speeds. Am. J. Eng. Applied Sci., 2: 154-159. DOI: 10.3844/ajeassp.2009.154.159

Semin S., A.R. Ismail and R.A. Bakar, 2009c. Diesel engine convert to port injection $\mathrm{CNG}$ engine using gaseous injector nozzle multi holes geometries improvement: A review. Am. J. Eng. Applied Sci., 2: 268-278. DOI: 10.3844/ajeassp.2009.268.278

Semin and R.A. Bakar, 2008. A technical review of compressed natural gas as an alternative fuel for internal combustion engines. Am. J. Eng. Applied Sci., 1: 302-311.

DOI: 10.3844 /ajeassp.2008.302.311

Sepúlveda, J.A.M., 2016. Outlook of municipal solid waste in Bogota (Colombia). Am. J. Eng. Applied Sci., 9: 477-483.

DOI: 10.3844/ajeassp.2016.477.483

Serebrennikov, A., D. Serebrennikov and Z. Hakimov, 2016. Polyethylene pipeline bending stresses at an installation. Am. J. Eng. Applied Sci., 9: 350-355. DOI: 10.3844 /ajeassp.2016.350.355

Shanmugam, K., 2016. Flow dynamic behavior of fish oil/silver nitrate solution in mini-channel, effect of alkane addition on flow pattern and interfacial tension. Am. J. Eng. Applied Sci., 9: 236-250.

DOI: 10.3844 /ajeassp.2016.236.250

Shruti, 2016. Comparison in cover media under stegnography: Digital media by hide and seek approach. Am. J. Eng. Applied Sci., 9: 297-302. DOI: 10.3844/ajeassp.2016.297.302

Stavridou, N., E. Efthymiou and C.C. Baniotopoulos, 2015a. Welded connections of wind turbine towers under fatigue loading: Finite element analysis and comparative study. Am. J. Eng. Applied Sci., 8: 489-503. DOI: 10.3844/ajeassp.2015.489.503

Stavridou, N., E. Efthymiou and C.C. Baniotopoulos, $2015 \mathrm{~b}$. Verification of anchoring in foundations of wind turbine towers. Am. J. Eng. Applied Sci., 8: 717-729. DOI: 10.3844/ajeassp.2015.717.729 
Suarez, L., T.M. Abu-Lebdeh, M. Picornell and S.A. Hamoush, 2016. Investigating the role of fly ash and silica fume in the cement hydration process. Am. J. Eng. Applied Sci., 9: 134-145. DOI: 10.3844 /ajeassp.2016.134.145

Syahrullah, O.I. and N. Sinaga, 2016. Optimization and prediction of motorcycle injection system performance with feed-forward back-propagation method Artificial Neural Network (ANN). Am. J. Eng. Applied Sci., 9: 222-235.

DOI: 10.3844/ajeassp.2016.222.235

Sylvester, O., I. Bibobra and O.N. Ogbon, 2015a. Well test and PTA for reservoir characterization of key properties. Am. J. Eng. Applied Sci., 8: 638-647. DOI: 10.3844/ajeassp.2015.638.647

Sylvester, O., I. Bibobra and O. Augustina, $2015 \mathrm{~b}$. Report on the evaluation of Ugua J2 and J3 reservoir performance. Am. J. Eng. Applied Sci., 8: 678-688. DOI: 10.3844/ajeassp.2015.678.688

Taher, S.A., R. Hematti and M. Nemati, 2008. Comparison of different control strategies in GAbased optimized UPFC controller in electric power systems. Am. J. Eng. Applied Sci., 1: 45-52. DOI: 10.3844/ajeassp.2008.45.52

Takeuchi, T., Y. Kinouchi, R. Matsui and T. Ogawa, 2015. Optimal arrangement of energy-dissipating members for seismic retrofitting of truss structures. Am. J. Eng. Applied Sci., 8: 455-464. DOI: 10.3844/ajeassp.2015.455.464

Taraza, D., N.A. Henein and W. Bryzik, 2001. The frequency analysis of the crankshaft's speed variation: A reliable tool for diesel engine diagnosis. J. Eng. Gas Turbines Power, 123: 428-432. DOI: $10.1115 / 1.1359479$

Tesar, D. and G.K. Matthew, 1974. The Design of Modeled Cam Systems. In: Cams and Cam Mechanisms, Rees Jones, J. (Ed.), MEP, London and Birmingham, Alabama.

Theansuwan, W. and K. Triratanasirichai, 2011. The biodiesel production from roast Thai sausage oil by transesterification reaction. Am. J. Eng. Applied Sci., 4: 130-132.

DOI: 10.3844/ajeassp.2011.130.132

Thongwan, T., A. Kangrang and S. Homwuttiwong, 2011. An estimation of rainfall using fuzzy setgenetic algorithms model. Am. J. Eng. Applied Sci., 4: 77-81. DOI: 10.3844/ajeassp.2011.77.81

Tourab, W., A. Babouri and M. Nemamcha, 2011. Experimental study of electromagnetic environment in the vicinity of high voltage lines. Am. J. Eng. Applied Sci., 4: 209-213. DOI: 10.3844/ajeassp.2011.209.213

Tsolakis, A.D. and K.G. Raptis, 2011. Comparison of maximum gear-tooth operating bending stresses derived from niemann's analytical procedure and the finite element method. Am. J. Eng. Applied Sci., 4: 350-354. DOI: 10.3844/ajeassp.2011.350.354
Vernardos, S.M. and C.J. Gantes, 2015. Cross-section optimization of sandwich-type cylindrical wind turbine towers. Am. J. Eng. Applied Sci., 8: 471-480. DOI: 10.3844/ajeassp.2015.471.480

Wang, L., T. Liu, Y. Zhang and X. Yuan, 2016. A methodology for continuous evaluation of cloud resiliency. Am. J. Eng. Applied Sci., 9: 264-273. DOI: 10.3844/ajeassp.2016.264.273

Wang, L., G. Wang and C.A. Alexander, 2015. Confluences among big data, finite element analysis and high-performance computing. Am. J. Eng. Applied Sci., 8: 767-774.

DOI: 10.3844/ajeassp.2015.767.774

Wang, J. and Y. Yagi, 2016. Fragment-based visual tracking with multiple representations. Am. J. Eng. Applied Sci., 9: 187-194.

DOI: 10.3844/ajeassp.2016.187.194

Waters, C., S. Ajinola and M. Salih, 2016. Dissolution sintering technique to create porous copper with sodium chloride using polyvinyl alcohol solution through powder metallurgy. Am. J. Eng. Applied Sci. 9: 155-165. DOI: 10.3844/ajeassp.2016.155.165

Wessels, L. and H. Raad, 2016. Recent advances in point of care diagnostic tools: A review. Am. J. Eng. Applied Sci., 9: 1088-1095. DOI: 10.3844/ajeassp.2016.1088.1095

Wiederrich, J.L. and B. Roth, 1974. Design of Low Vibration Cam Profiles. In: Cams and Cam Mechanisms, Rees Jones, J. (Ed.), MEP, London and Birmingham, Alabama.

Yan, C., F. Gao and W. Guo, 2009. Coordinated kinematic modeling for motion planning of heavyduty manipulators in an integrated open-die forging center. J. Eng. Manufacture, 223: 1299-1313.

Yang, M.F. and Y. Lin, 2015. Process is unreliable and quantity discounts supply chain integration inventory model. Am. J. Eng. Applied Sci., 8: 602610. DOI: 10.3844/ajeassp.2015.602.610

Yeargin, R., R. Ramey and C. Waters, 2016. Porosity analysis in porous brass using dual approaches. Am. J. Eng. Applied Sci., 9: 91-97. DOI: 10.3844 /ajeassp.2016.91.97

You, M., X. Huang, M. Lin, Q. Tong and X. Li et al., 2016. Preparation of $\mathrm{LiCoMnO}_{4}$ assisted by hydrothermal approach and its electrochemical performance. Am. J. Eng. Applied Sci., 9: 396-405. DOI: 10.3844/ajeassp.2016.396.405

Zeferino, R.S., J.A.R. Ramón, E. de Anda Reyes, R.S. González and U. Pal, 2016. Large scale synthesis of $\mathrm{ZnO}$ nanostructures of different morphologies through solvent-free mechanochemical synthesis and their application in photocatalytic dye degradation. Am. J. Eng. Applied Sci., 9: 41-52. DOI: 10.3844/ajeassp.2016.41.52

Zhao, K., H. Wang, G.L. Chen, Z.Q. Lin and Y.B. He, 2010. Compliance process analysis for forging manipulator. J. Mech. Eng., 46: 27-34. 
Zhao, B., 2013. Identification of multi-cracks in the gate rotor shaft based on the wavelet finite element method. Am. J. Eng. Applied Sci., 6: 309-319.

DOI: 10.3844/ajeassp.2013.309.319

Zheng, H. and S. Li, 2016. Fast and robust maximum power point tracking for solar photovoltaic systems. Am. J. Eng. Applied Sci., 9: 755-769. DOI: 10.3844/ajeassp.2016.755.769

Zotos, I.S. and T.N. Costopoulos, 2009. On the use of rolling element bearings' models in Precision maintenance. Am. J. Eng. Applied Sci., 2: 344-352. DOI: 10.3844/ajeassp.2009.344.352

Zulkifli, R., K. Sopian, S. Abdullah and M.S. Takriff, 2008. Effect of pulsating circular hot air jet frequencies on local and average nusselt number. Am. J. Eng. Applied Sci., 1: 57-61. DOI: 10.3844/ajeassp.2008.57.61

Zulkifli, R., K. Sopian, S. Abdullah and M.S. Takriff, 2009. Experimental study of flow structures of circular pulsating air jet. Am. J. Eng. Applied Sci., 2: 171-175. DOI: 10.3844/ajeassp.2009.171.175
Zurfi, A. and J. Zhang, 2016a. Model identification and wall-plug efficiency measurement of white LED modules. Am. J. Eng. Applied Sci., 9: 412-419. DOI: 10.3844/ajeassp.2016.412.419

Zurfi, A. and J. Zhang, 2016b. Exploitation of battery energy storage in load frequency control-a literature survey. Am. J. Eng. Applied Sci., 9: 1173-1188. DOI: 10.3844/ajeassp.2016.1173.1188

\section{Source of Figures:}

Petrescu, 2008, 2011, 2015a 